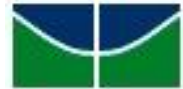

UnB

UNIVERSIDADE DE BRASÍLIA - UNB

CENTRO DE EXCELÊNCIA EM TURISMO

PROGRAMA DE MESTRADO PROFISSIONAL
\end{abstract}

Imaginário e Experiência Turística no Sítio Arqueológico Bisnau

Formosa - Goiás: Praticando espaços e construindo lugares

Hugo Emanuel de Almeida

Matrícula: 130085006

Orientadora: Prof ${ }^{\mathrm{a}} . \mathrm{Dr}^{\mathrm{a}}$ Karina Silva Dias

Brasília

Julho/2015 


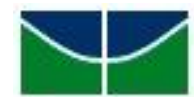

UnB

UNIVERSIDADE DE BRASÍLIA - UNB

CENTRO DE EXCELÊNCIA EM TURISMO

PROGRAMA DE MESTRADO PROFISSIONAL
\end{abstract}

\title{
Imaginário e Experiência Turística no Sítio Arqueológico Bisnau \\ Formosa - Goiás: Praticando espaços e construindo lugares
}

Hugo Emanuel de Almeida
Dissertação Apresentada ao Mestrado Profissional Em Turismo Da Universidade De Brasília Como Requisito Para Obtenção De Título De Mestre.
Orientadora: Prof ${ }^{\mathrm{a}} . \mathrm{Dr}^{\mathrm{a}}$ Karina Silva Dias
Banca Examinadora

Prof $^{\mathrm{a}}$. Dr ${ }^{\mathrm{a}}$ Karina Silva Dias

Orientadora

Prof $^{\mathrm{a}}$. Dr ${ }^{\mathrm{a}}$ Christus Nóbrega

Avaliador Externo

Prof $^{\mathrm{a}}$. Dr ${ }^{\mathrm{a}}$ Luiz Carlos Spiller Pena

Avaliador Interno

Prof $^{\mathrm{a}}$. Dr ${ }^{\mathrm{a}}$ Iara Lucia Gomes Brasileiro

Avaliador Suplente 
Almeida, Hugo Emanuel de

Imaginário e Experiência Turística no Sítio

Arqueológico Bisnau Formosa - Goiás: Praticando espaços

e construindo lugares / Hugo Emanuel de Almeida;

orientador Karina Silva Dias. -- Brasilia, 2015. $125 \mathrm{p}$.

Dissertação (Mestrado - Mestrado Profissional em Turismo) -- Universidade de Brasilia, 2015.

1. Turismo. 2. Arqueologia. 3. Imaginário. 4. Experiência. 5. Espaço e Lugar. I. Dias, Karina Silva, orient. II. Título. 
Dedico este trabalho aos meus pais, Alice Pereira de Almeida e Eliseno Tadeu de Almeida 


\section{AGRADECIMENTOS}

A DEUS sobre tudo e todas as coisas,

Aos meus pais, Eliseno Tadeu de Almeida e Alice Pereira de Almeida por todo amor, incentivo e suporte em toda minha vida.

Aos meus irmãos por todo aprendizado ao longo da vida.

À Karina Silva Dias, por todos os direcionamentos e por me ensinar a ver a poesia na ciência.

À Maria Lúcia Franco Pardi pelas possiblidades do apresentadas para meu crescimento acadêmico e humano.

À Dalila Feitosa de Souza por me ensinar o valor de não desistir e sempre perseverar

À Ingra Cunha Teles de Carvalho, pela recepção e por todos os anos de convivência.

À Denise Fonseca Santos por a cada dia me mostrar o valor da humildade e humanidade

À Taís Pereira Martins, pelas conversas e risos e todo aconchego nos momentos improdutivos, de quase desespero.

A todos da empresa Ecotech Ambiental, pela confiança, pelo crescimento profissional e pela amizade de cada um.

A todos do mestrado que de alguma forma contribuirão nessa caminhada.

E a cada um que esteve envolvido nesse processo. 


\section{RESUMO}

Esse trabalho procura analisar como o imaginário acerca do sítio arqueológico Bisnau em Formosa- Goiás influencia no deslocamento turístico a esse atrativo e como, através das diversas possibilidades de experiência nesse destino são transformados os sujeitos, e os espaços que por eles são praticados. As infinitas relações do homem no espaço turístico do sítio arqueológico Bisnau irão revelar maior ou menor intimidade com este espaço, esses diferentes graus de relacionamento estabelecidos entre homem e meio serão elucidativos para entendermos como os homens se ligam aos espaços e os transformam em lugar. Através dos relatos e outras narrativas sobre a experiência de visitação ao lajedo rupestre do Bisnau, procuramos observar algumas manifestações que pudessem revelar uma intimidade nessa relação entre os turistas e o atrativo visitado. Destarte, essa relação dos homens no mundo, delimitado aqui no âmbito do espaço turístico, gera a partir da experiência num espaço geográfico um espaço subjetivo e simbólico. Esta pesquisa, dessa forma, é um olhar sobre alguns aspectos mais sensíveis e subjetivos do fenômeno turístico no sítio arqueológico Bisnau $O$ imaginário influencia nas mais variadas experiências dos turistas no espaço, desencadeando sentimentos e valores que revelam lugares vividos, Esses conceitos - imaginário, experiência, espaço e lugar - são trazidos nessa pesquisa para demonstrar parte da realidade do turismo ao sítio arqueológico Bisnau e como eu, enquanto pesquisador, o percebo, procurando revelar a potencialidade que a região do Bisnau possui principalmente presente na aura mística contida no imaginário desse lugar. O sítio Bisnau, caracteriza-se pela presença de desenhos gravados num lajedo à céu aberto e, são em sua maioria geométricos. Essas inscrições rupestres em baixo relevo são conhecidas na arqueologia como petróglifos. Esse sítio, que recebe a visitação de diferentes interessados, até mesmos os curiosos, revela variadas possibilidades de interpretação, são essas versões sobre o espaço visitado que revelaram a relação mais intima dos homens nos lugares experimentados.

Palavras-Chave: Turismo, Arqueologia, Imaginário, Experiência, Espaço e lugar. 


\begin{abstract}
This paper aims to analyze how the imaginary related to the Bisnau archaeological site in Formosa - Goiás influences the tourist displacement to this attraction and how, through several possibilities of experience in this destination, the subjects are changed, and the spaces that are practiced by them. The endless human relations in the tourist area of Bisnau archeological site are going to reveal more or less intimacy with this space, these different levels of relationship established between man and space will be enlightening to understand how the individuals are connected to the spaces and transform them into place. Through reports and other narratives about the visitation experience on the rock flagstones of Bisnau, we tried to observe some events that might reveal an intimacy in this relationship between the tourists and the visited attraction. Thus, this relationship of men in the world, defined here within the tourist space, generates from the experience in a geographic space a subjective and symbolic space. This research, therefore, is a glance at some more sensitive and subjective aspects of the tourist phenomenon in the Bisnau archaeological site. The imaginary influences in several tourist experiences in the space, triggering feelings and values that reveal places lived. These concepts - imaginary, experience, space and place - are brought to this research to demonstrate part of the tourism reality to the Bisnau archaeological site, and how I, as researcher, realize it, trying to show the potential that Bisnau region has, mainly, present in the mystical aura contained in the imaginary of this place. Bisnau site is characterized by the presence of drawings engraved in an open flagstone and most of them are geometrical. These rock inscriptions in low relief are known in Archeology as petroglyphs. This site, which receives visits from different stakeholders, even some curious ones, reveals several possible interpretations, they are these versions of the visited area that revealed the most intimate relationship of men in the experienced places.
\end{abstract}

Key words: Tourism, Archeology, Imaginary, Experience, Space and place. 


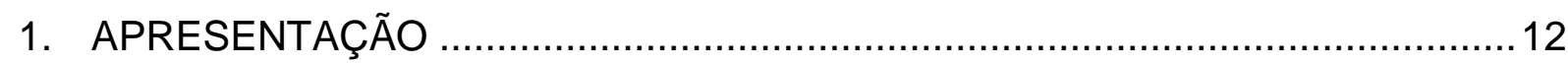

2. BAGAGEM DE MÃO: APARATOS BÁSICOS PARA A VIAGEM .......................25

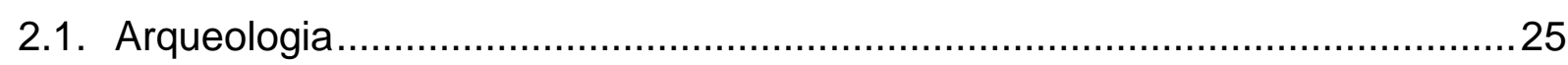

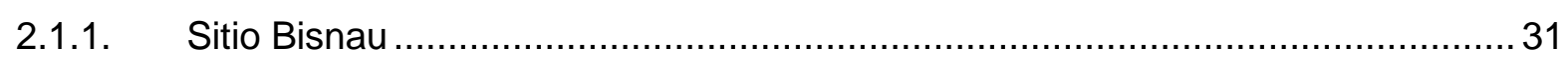

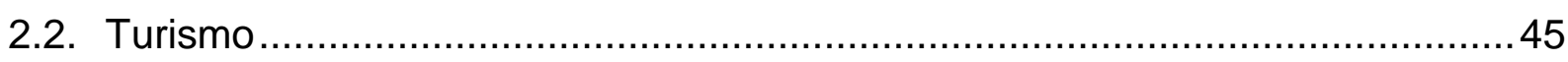

2.3. Pensar Turismo Arqueológico Pensando em Turismo .....................................51

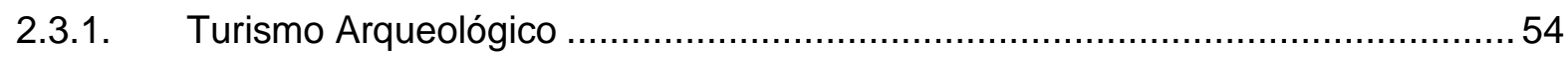

3. CAMINHOS E POUSOS: A EXPERIÊNCIA TURÍSTICA REPOUSA NO

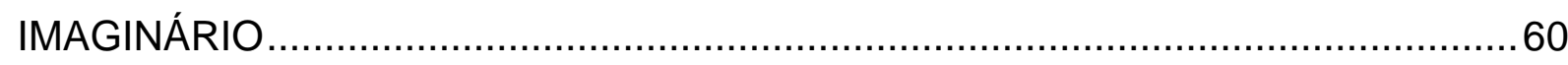

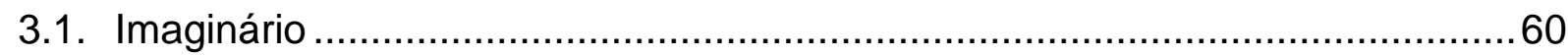

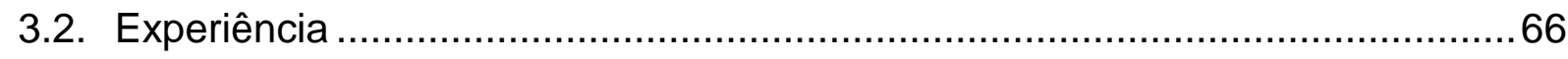

4. ENTRE ESPAÇOS e ENTRE-LUGARES ………......................................

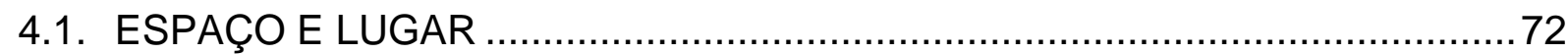

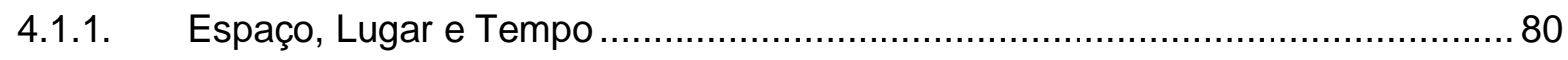

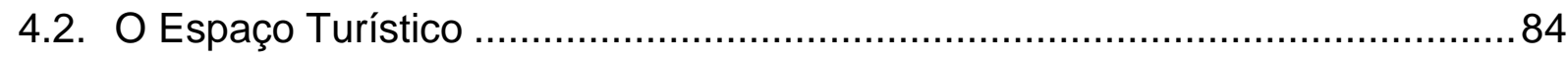

4.2.1. Lugares, Não-Lugares e Entre-Lugares do Espaço Turístico ............................. 86

4.3. O Imaginário Na Experiência: Construindo Versões Sobre O Sítio Bisnau .......88

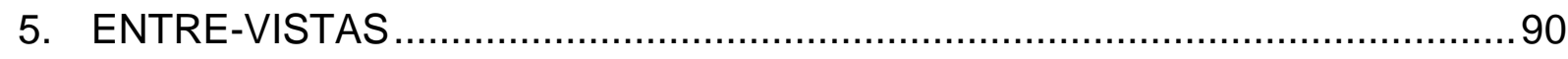

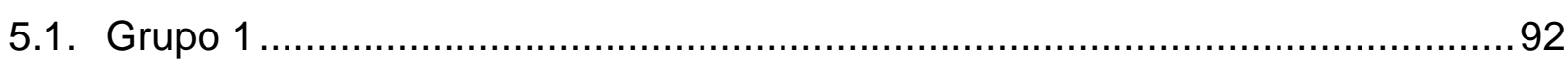

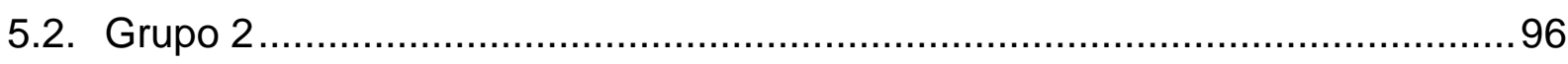

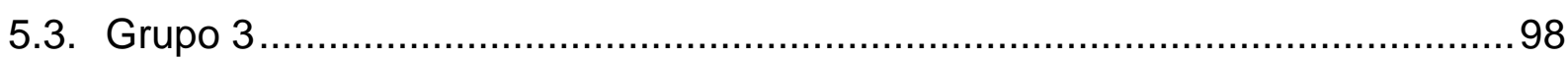

6. INVESTIGANDO AS NARRATIVAS E REVELANDO ESPAÇOS E LUGARES101

6.1. Traços, Bichos e Coisas ......................................................................... 104

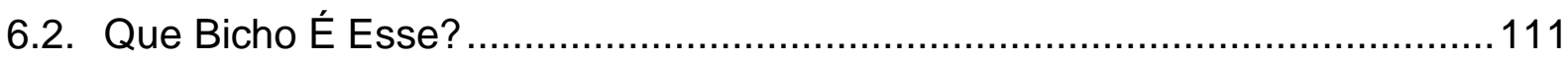

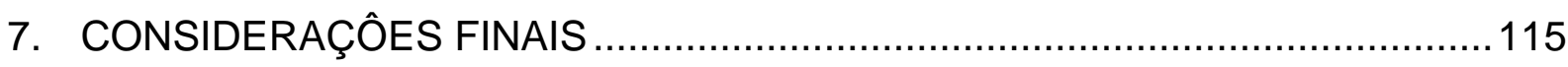

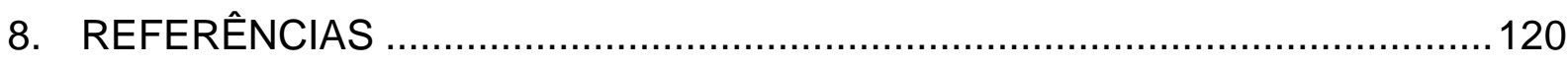




\section{LISTA FIGURAS}

Figura 1: Motivos recorrentes em Serranópolis, Goiás

Figura 2: Sítios arqueológicos antigos nas savanas tropicais: 1. Alto Sucuriú, MS; 2. Serranópolis, 3. Rio do Peixe; 4. Caiapônia, 5. Uruaçu, 6. formadores do rio Tocantins, GO; 7. Rio Paranã, 8. UHE Serra da Mesa, TO; 9. Serra do Cipó, 10. Varzelândia, 11. Vale do Peruaçu, MG; 12. Serra Geral, BA; 13. Itaparica, 14. Bom Jardim, PE; 15. Rio Açu, 16. Litoral, RN; 17. São Raimundo Nonato, PI. Fonte: SCHMITZ (2003). 28

Figura 3: Localização dos sítios arqueológicos Bisnau, Toca da Onça da Capetinga e Toca da Onça de Formosa, todos inseridos nos limites do município de Formosa-Goiás. 32

Figura 4: Motivos Recorrentes da Tradição Litorânea (SC). Fonte: PROUS (1992) ........................... 35

Figura 5: Motivos recorrentes da tradição Nordestina. Fonte: PROUS (1992) 37

Figura 6: Distancia entre os sítios arqueológicos Binau, Toca da Onça da Capetinga e Toca da Onça de Formosa. O numeral 3 exposto na figura representa a pamonharia do Bisnau. 40

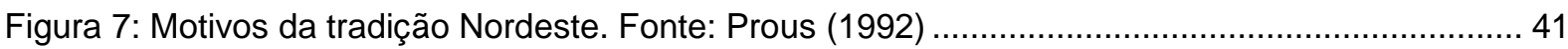

Figura 8: Pamonharia do Bisnau e Sítios Bisnau e Toca da Onça da Capetinga ................................. 79 


\section{LISTA DE FOTOS}

Foto 1: Sítio Bisnau. Lajedo rupestre. Disposição inclinada do lajedo. ............................................. 14

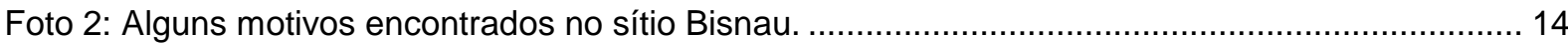

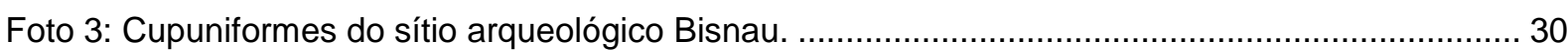

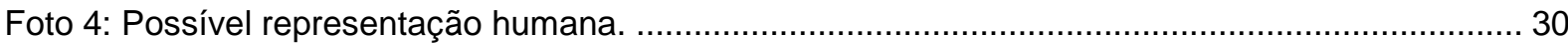

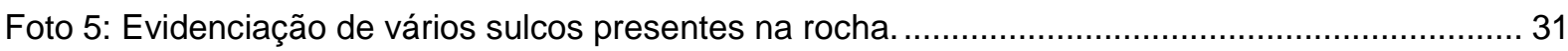

Foto 6: Sequência de pontos incisos na rocha e círculos unidos por uma linha. Foto: Hugo Emanuel.

Foto 7: Motivos do sítio arqueológico Bisnau semelhantes a tradição Litorânea . Foto: Hugo Emanuel. 36

Foto 8: Motivos do sítio arqueológico Bisnau semelhantes a tradição Litorânea . Foto: Hugo Emanuel. Foto: Hugo Emanuel.

Foto 9: Motivos do sítio arqueológico Bisnau semelhantes a tradição geométrica nordestina observados na Pedra Lavrada no município de Ingá na Paraíba. Foto: Hugo Emanuel.

Foto 10: Motivos do sítio arqueológico Bisnau semelhantes a tradição geométrica nordestina observados na Pedra Lavrada no município de Ingá na Paraíba. Foto: Hugo Emanuel. 37

Foto 11: Grafismos do lajedo do Bisnau semelhante a representação destacada na figura da tradição nordestina e Pedra lavrada, município de Picuí na Paraíba. Foto Hugo Emanuel. 38

Foto 12: Desenho rupestre biomorfo. Toca da Onça da Capetinga, Formosa-Go. Foto: Hugo Emanuel.

Foto 13: Pinturas do sítio Toca da Onça de Formosa. 41

Foto 14: Gravuras do sítio Bisnau semelhante aos observados na figura 6...................................... 42

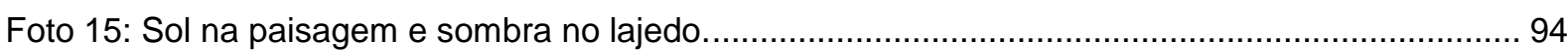

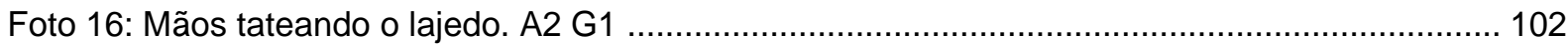

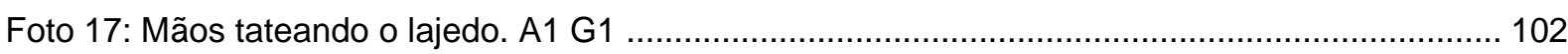

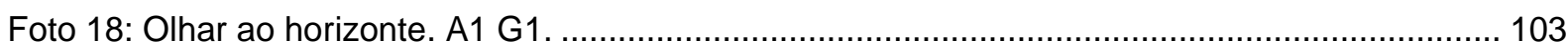

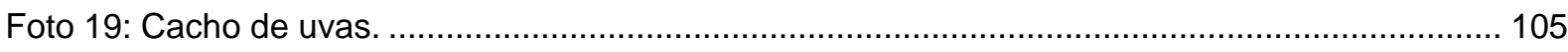

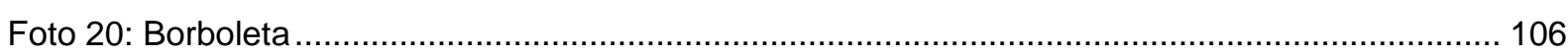

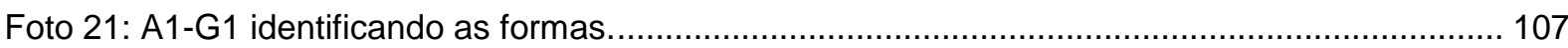

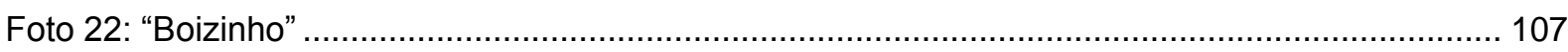

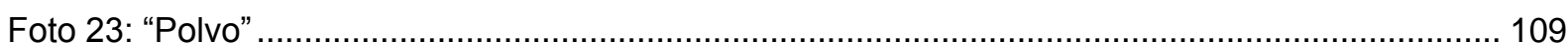

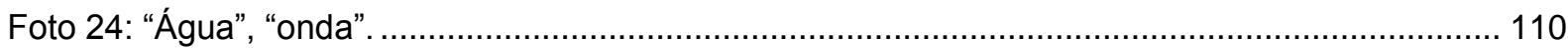

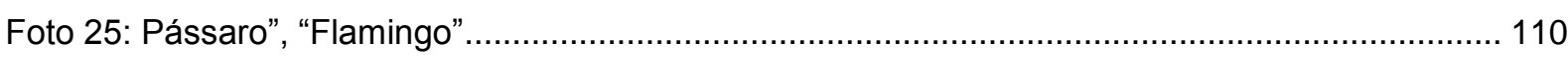

Foto 26: Para a maioria dos entrevistados é uma representação humana. ..................................... 111 
INTRODUÇÃO

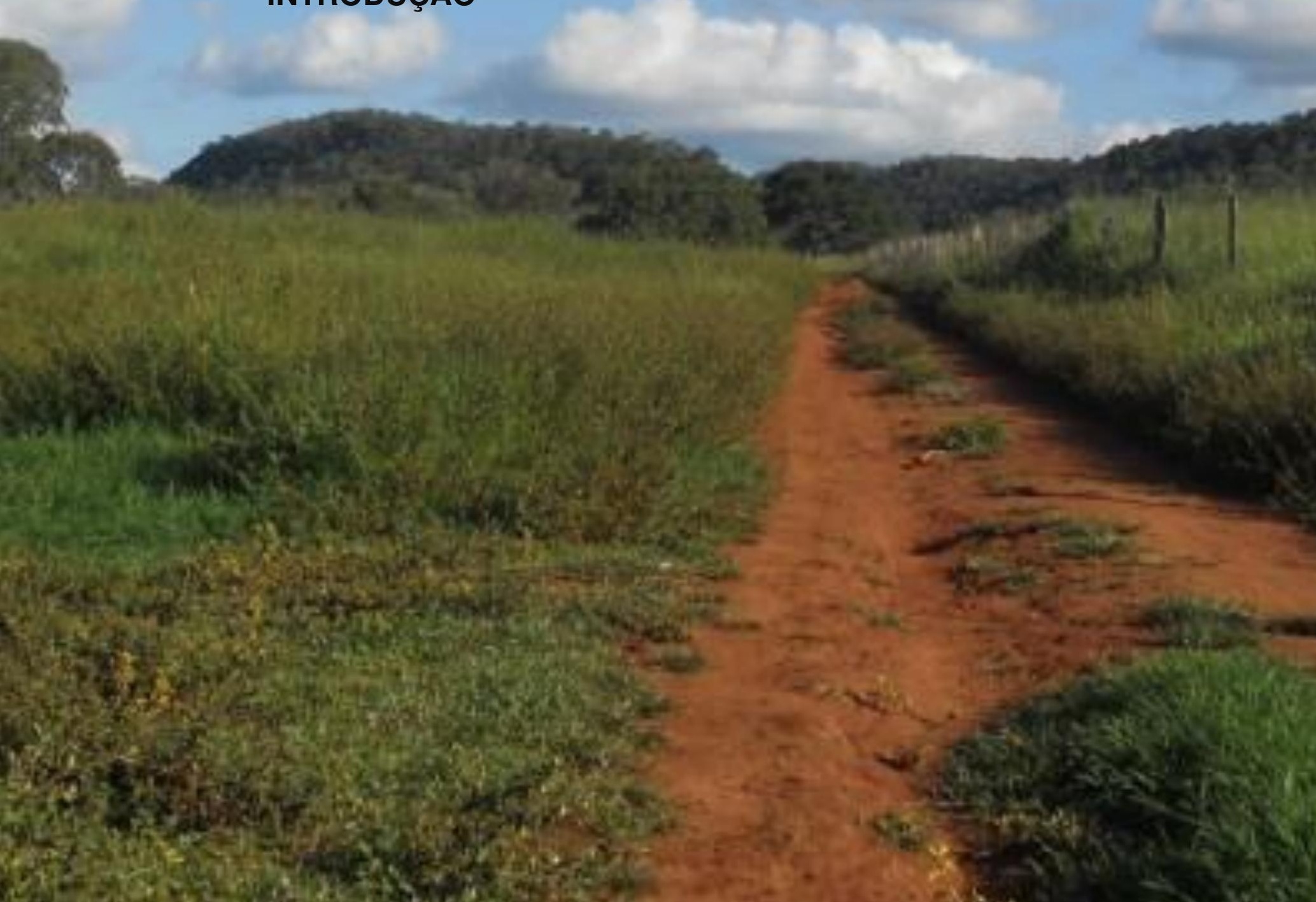




\section{APRESENTAÇÃO}

A pesquisa aqui desenvolvida pretende analisar parte do processo que leva ao deslocamento turístico ao sítio arqueológico Bisnau em Formosa, Goiás e como essa experiência é transformadora. O turismo, que envolve tanto aspectos físicos quanto psicológicos e imateriais deve ser pensado na convergência desses fatores, para que o entendimento acerca desse fenômeno seja amplo e consistente. Como proposta auxiliar pretende-se delinear além do contexto arqueológico regional algumas características do complexo arqueológico do Bisnau e suas interfaces com o turismo e a comunidade local. .

Essa pesquisa será, portanto, desenvolvida integrando duas grandes áreas de estudo, o turismo e a arqueologia, onde caberá nessa dissertação apenas estudos bibliográficos e descritivos para contextualização arqueológica, sendo, portanto, o fenômeno turístico nesse espaço o foco da pesquisa.

O turismo implica deslocamento, que por sua vez é acionado por determinada motivação da ordem dos desejos ou das necessidades. Podemos considerar dois principais movimentos que se realizam para a efetivação do deslocamento turístico, primeiro, a experiência conceitual da tomada de consciência sobre algum destino ou atrativo, segundo a própria vivencia física corporal da visitação. A ação é sempre seguida de uma experiência, essa "experiência modifica o sujeito, fazendo-o refletir sobre o momento vivido, cruzando as sensações do presente com a carga de experiência vivida anteriormente" (GASTAL e MOESCH, 2007), armazenada no imaginário. É no campo do imaginário que a ação primeira gera motivação para que haja a segunda ação, o deslocamento, no nosso caso, a visita turística.

As diversas construções da realidade acerca do espaço arqueológico fundam e influem no imaginário gerando menor ou maior motivação para experiência turística. Esses discursos legitimados e/ou legitimadores, populares ou científicos, compõe igualmente a realidade. 
A experiência do sujeito no mundo invariavelmente acontece nos planos físico e imaterial. $O$ turismo também pressupõe esses dois planos. Fazer turismo implica deslocamento voluntário, este, acontece no espaço físico. A voluntariedade parte de desejos e vontades criadas ainda no plano imaterial no campo da imaginação e do imaginário. A mídia veicula belas imagens e paisagens que nos são anunciadas como atrativos turísticos, disto, trabalhamos a ideia, imaginamos as possibilidades e as futuras experiências. Nossa imaginação, porém, caminha no campo do imaginário, campo que "agrega imagens, sentimentos, lembranças, experiências [...] leituras de vida e, através de um mecanismo individual/grupal, sedimenta um modo de ver, de ser, de agir, de sentir e aspirar ao estar no mundo" (MACHADO apud GASTAL, 2005).

Variadas sociedades e/ou grupos partilham de certo imaginário, os quais, por sua vez, vão influenciar nas experiências futuras do sujeito que vive. Essas novas experiências, que acontecem a todo tempo, retroalimentarão o imaginário. É um movimento circular, em que as experiências são influenciadas pelo imaginário e essas experiências comporão o substrato de novas experiências. O imaginário então, "emana do real, estrutura-se como ideal e retorna ao real como elemento propulsor" (MACHADO apud GASTAL, 2005).

Deve ser destacado como explicito em um dos excertos acima que o campo do imaginário é um mecanismo individual/grupal e que apesar de haver uma comunhão cada experiência é única, portanto, o imaginário de cada sujeito também é singular.

O imaginário enquanto "elemento propulsor" influenciará no deslocamento do sujeito turista ao destino imaginado, bem como nas experiências em todos os instantes da viagem. A cada estranhamento, 0 individuo confrontará o imaginado com o percebido. Essa experiência faz o sujeito refletir e se transformar, podendo também transformar e (re)carregar seu imaginário.

A nossa viagem tem como destino o sítio arqueológico Bisnau, localizado no município de Formosa-Goiás, sendo, portanto, o espaço escolhido como lócus dessa pesquisa. O local já recebe visitação, porém parece ser pouco contemplado, uma 
vez que é privilegiada a visita ao lajedo ${ }^{1}$ rupestre, marginalizando os demais potenciais atrativos, e reduzindo as possibilidades perceptivas.

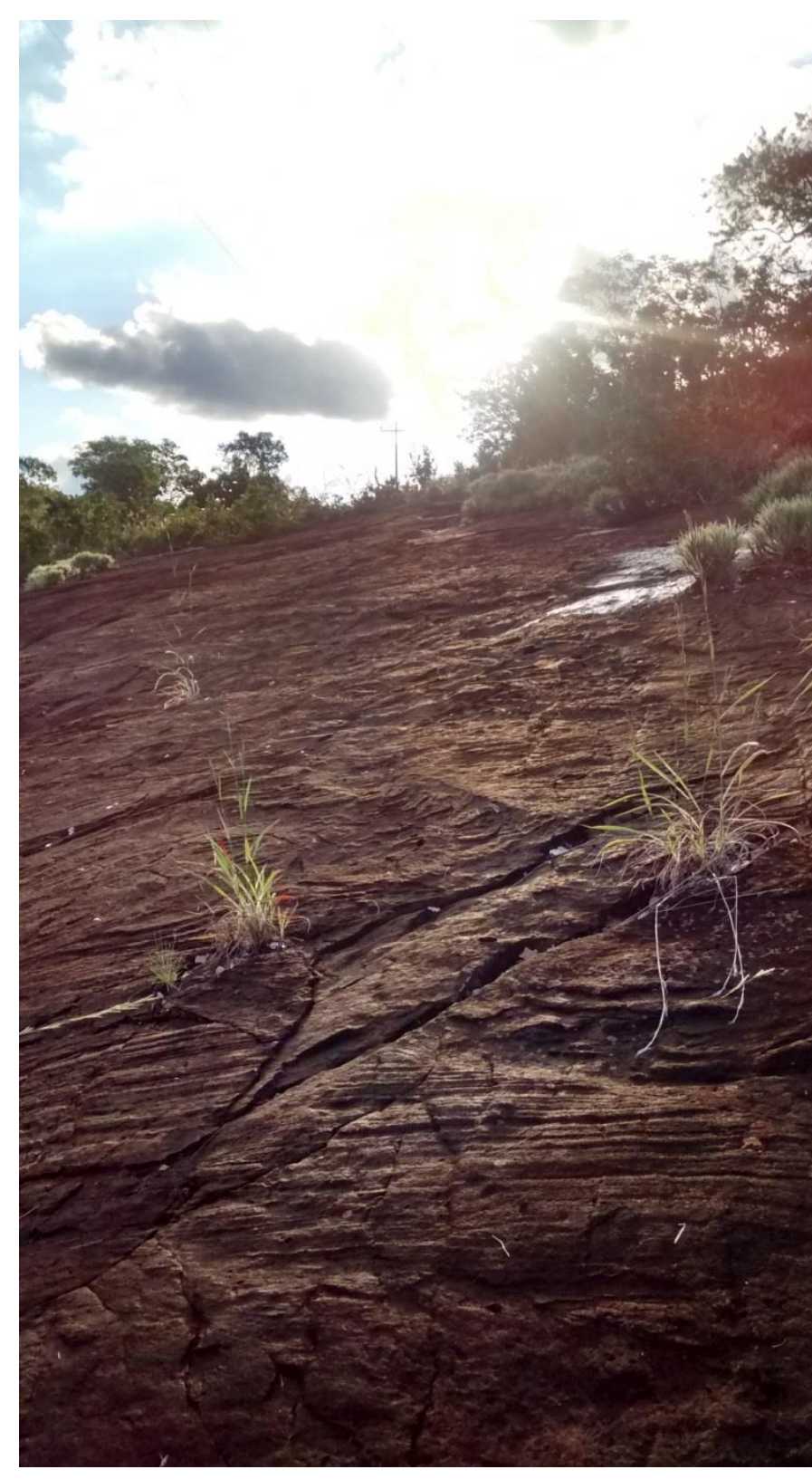

Foto 1: Sítio Bisnau. Lajedo rupestre. Disposição inclinada do lajedo.
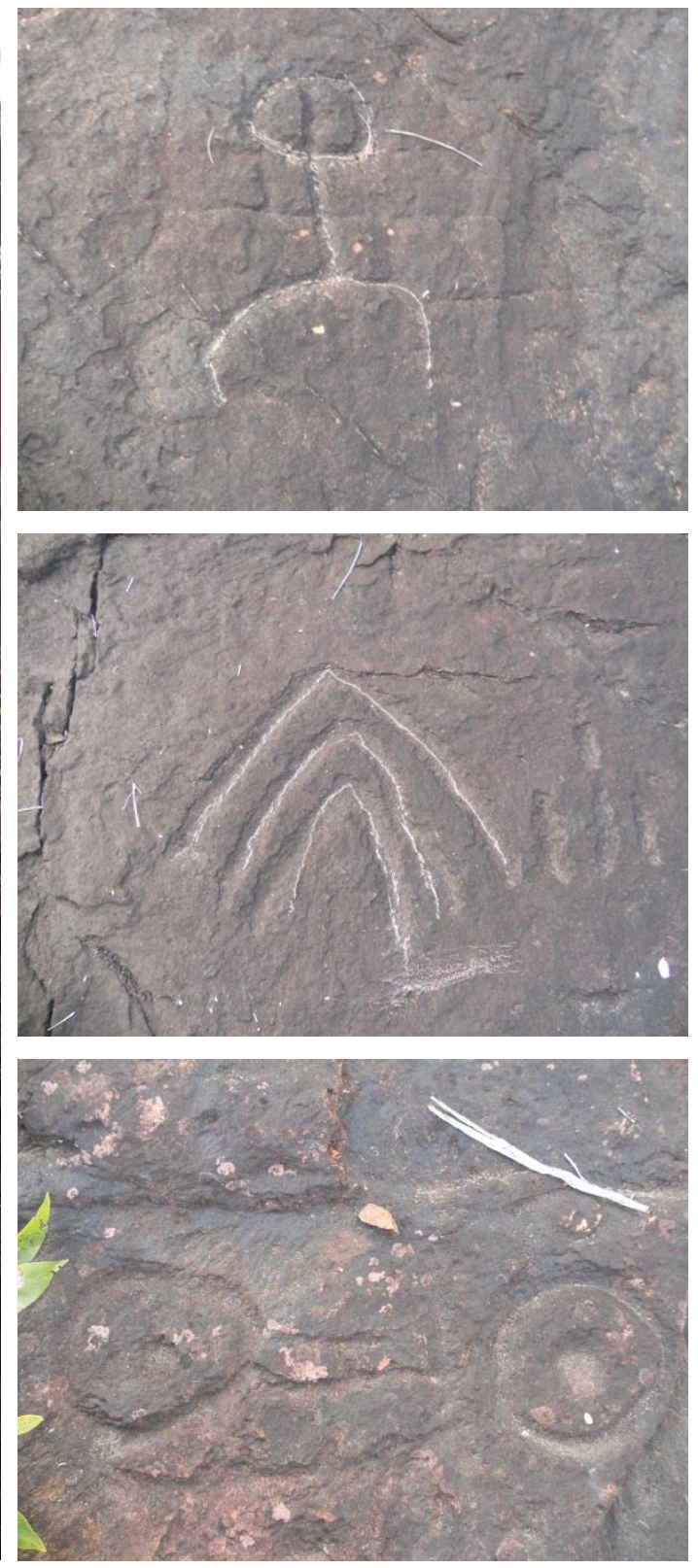

Foto 2: Alguns motivos encontrados no sítio Bisnau.

\footnotetext{
${ }^{1}$ Afloramento de rocha nas proximidades de um curso d'água.
} 
Além do lajedo rupestre que provavelmente perfaz atrativo principal da área, destaco dois outros espaços, suprimidos da visitação ${ }^{2}$ e que acrescentariam nas possibilidades de experiência turística a esse complexo arqueológico caso fosse agregado a um roteiro, a cachoeira do Rio Bisnau e Toca da Onça da Capetinga ${ }^{3}$, provavelmente ambientes de um mesmo período histórico e que hoje nos é possível vivenciar.

Devemos pensar então numa experiência para além do lajedo composto pelas inscrições milenares, para sentir o ambiente como um todo, um complexo vivencial, que experimentado no passado desempenhou certo papel e desencadeou determinadas sensações àquelas populações que ali habitaram, hoje, como um rastro desse tempo que chega até nós, pode ser novamente experimentado, agora, do nosso jeito.

As experiências acontecem a todo instante e seria ingênuo caracterizar um turismo ao sítio arqueológico Bisnau numa experiência restrita ao lajedo rupestre. Todo o caminho faz parte, a saída do seu mundo cotidiano, o trajeto, a visita, toda essa vivencia de espaços vai compor um espaço turístico experimentado.

O turismo, para além de seus traços mercadológicos e políticos se apresenta como fenômeno social que se configura sempre com um sujeito que se relaciona com o mundo e com o outro. Essa relação se dá através de uma experiência, seja conceitual ou concreta. Turismo pressupõe deslocamento, por sua vez, deslocamentos pressupõem desejos, necessidades, ou seja, partem de motivações.

O turismo, muito mais voltado à deslocamentos voluntários se aproxima dos pressupostos dos desejos. Mas de onde partem as motivações? Dos desejos!? E de onde partem os desejos? Nesse trabalho, portanto, se buscou levantar como o campo do imaginário influencia nos processos envolvidos na tomada de decisão

\footnotetext{
${ }^{2}$ Além de pouco pesquisada arqueologicamente - o que diminui o conhecimento acerca da ocupação humana da área e consequentemente possíveis atrativos turísticos se bem manejados - a região do sítio Bisnau não possui um plano ou iniciativas que agreguem os diversos atrativos conhecidos na região num roteiro turístico comum.

${ }^{3}$ Sítio arqueológico de pintura rupestre inserido em ambiente de abrigo, localizado nas imediações dos petróglifos do Bisnau.
} 
para se fazer turismo no sítio arqueológico Bisnau, e como essa experiência turística transforma a percepção e o sujeito que vivencia esse espaço.

Motivado e pronto para sua viagem o turista imagina seu destino e, anseia pela experiência. A experiência enquanto transformadora de ideias e conceitos instaura uma nova percepção no momento que o espaço é vivido, dando-lhe relevo. Momento este de infinitas possibilidades.

Mas como o imaginário influencia no deslocamento e na experiência ao sítio arqueológico Bisnau e como a visitação - possibilidade de experiência física desse espaço - transforma os sujeitos e o espaço, podendo rearranjar o imaginado acerca do destino?

O imaginário é acionado no momento que experimentamos o mundo. No turismo os planos de marketing e as propagandas tratam, através de imagens e narrativas, de atingir nosso imaginário. Refletir acerca desse conceito é pensar em turismo. Assim, entendemos que é preciso diversificar as experiências, para que mais percepções sejam instauradas aumentando as possibilidades de se atingir o imaginário, gerar motivação e consequentemente que seja estabelecida alguma relação do sujeito com o espaço visitado.

Como intuito secundário, será proposta uma readequação do roteiro hoje estabelecido, agregando novos espaços, incitando uma diversificação das experiências para que mais sensações sejam realizadas, possibilitando assim, a construção de novos imaginários.

Esse trabalho pode corroborar para o entendimento de como um sujeito turista se motiva a experienciar um sítio arqueológico e como essa experiência transforma 0 sujeito e os espaços pode rearranjar a realidade percebida, tentando dessa forma, analisar vieses mais subjetivos do fenômeno, já que se trata de um fenômeno social. 
Mas de que forma então, o imaginário direciona a experiência turística ao sítio arqueológico Bisnau e como essa experiência reconfigura o imaginado construindo novas versões do sítio visitado? Foi investigado, portanto, como o imaginário influencia no fazer turismo e de que forma essa experiência reconfigura e re(cria) imaginários.

Partimos da coleta de relatos obtidos através de entrevistas para investigar como a experiência ao sítio arqueológico se deu e de que forma o imaginário influenciou e foi transformado.

Essa pesquisa estabeleceu uma análise exploratória do fenômeno turístico e a escolha de qual método seguir partiu do pesquisador que, de acordo com seus objetivos, adequa sua pesquisa para alcançar resultados mais satisfatórios para suas indagações. O método designa um modo básico de conhecer [...] Ele é construído em cada caso, em cada projeto de pesquisa (PAVIANI, 2009).

Para além de uma realidade estática o fenômeno turístico deve ser pensado considerando sua dinamicidade já que é fundamentalmente prescrita por relações sociais altamente flexíveis e mutantes. Dessa forma assume-se que nenhuma análise deve ser definitiva, o real contém uma infinidade de "essências" (possibilidades) que é necessário trazer a luz (BRUYNE, 1991).

Este trabalho, partiu do desejo de se levantar questões mais subjetivas relativas a experiência turística em um sítio arqueológico e vê na fenomenologia o caminho mais apropriado para que a problemática seja trabalhada em amplitude e para que o movimento do sujeito nessa experiência seja investigado numa tentativa de entender parte dessa realidade. A fenomenologia vincula sua concepção da realidade a partir da experiência do homem no mundo, e com o outro. A busca do significado da experiência será sempre o fim último da pesquisa fenomenológica (MOREIRA, 2004). 
O turismo envolve necessidades, anseios, e desejos humanos, bem como motivações psicológicas que são fundamentais na definição do que é o turismo (PANOSSSO, 2005). Não tendo a audácia prematura de definir o que é o turismo, pretendemos aqui, considerando os meandros da subjetividade inerente a esse fenômeno, traçar alguns aspectos que levam a experiência turística no sítio arqueológico Bisnau e como essa experiência se dá.

O método fenomenológico juntamente às demais pesquisas qualitativas rompem com as premissas essencialmente positivistas e rechaçam a exclusiva objetividade exterior do mundo. Essa análise (fenomenológica) contesta as aparências empíricas, porém considera que essas aparências podem bastar para a prática, mas não constituem um conhecimento científico (BRUYNE, 1991. P. 75).

Como afirma Merleau-Ponty para uma análise fenomenológica "o real deve ser descrito e não construído ou constituído. Isso quer dizer que não posso assimilar a percepção às sínteses que pertencem à ordem do juízo, dos atos ou da predicação" (MERLEAU-PONTY, 1999).

Dado que o caminho que se pretende seguir aqui, é basicamente a descrição da experiência, a entrevista tem sido o instrumento amplamente utilizado por pesquisadores fenomenológicos, dada à complexidade que se apresenta o fenômeno turístico (MOREIRA, 2004). Nesta pesquisa, portanto, como técnica de coleta de dados, será utilizada a entrevista, que realizadas no momento da experiência registrarão parte da percepção, portanto, parte da realidade vivida.

A experiência turística em um sítio arqueológico desencadeia novas percepções, que se dão num espaço estranho ao mundo cotidiano. A percepção do mundo aqui, não são meros reflexos dos objetos na retina, existem processos externos, internos, históricos, que configuram essa experiência.

As entrevistas foram realizadas com seis participantes, sendo que seus relatos foram coletados em dois momentos distintos. Primeiro antes mesmo da experiência no sítio arqueológico Bisnau e num segundo momento, pós-visita. Assim, pretendeu- 
se investigar que tipo de imaginário se tinha desse espaço antes da experiência in loco e se essa experiência acarretou na mudança de discurso sobre o sítio.

O intuito último desse processo é analisar esses relatos como versões do que é o espaço do sítio arqueológico Bisnau bem como das suas inscrições ou petróglifos ${ }^{4}$, a partir da percepção da realidade vivida. Essas versões, juntamente com outras, como da população vizinha ao sítio e da comunidade cientifica, comporão um glossário, com figuras representativas dos petróglifos e suas respectivas descrições/versões.

Como desenvolvido acima, os conceitos de experiência e imaginário são o cerne teórico dessa pesquisa, que, portanto, parte desses meios elucidativos para compreensão do fazer turismo no sítio arqueológico Bisnau em formosa-Goiás.

Tal fenômeno se desenvolve nos planos físico, social e psicológico, o que determina ao menos que se admita que tal fenômeno aconteça na sinergia entre tais esferas. Acreditando nisso, serão delineados tanto os aspectos imateriais do turismo como os aspectos físicos, estes últimos, sempre pensados na sua relação com os homens. No campo imaterial teremos principalmente o conceito de imaginário para desenvolver as análises. No plano físico partiremos da premissa básica que para se fazer turismo tem de haver deslocamento, que só pode acontecer no espaço físico.

Assim, a partir da experiência dos sujeitos turistas no mundo banhada pelo imaginário individual/cotelivo os espaços vividos passarão a receber do sujeito que vivencia, forma e conteúdo, fato este que enseja uma nova dimensão no plano do vivido, uma relação mais intima e estreita dos indivíduos com os espaços experimentados.

Normalmente no momento que antecede a visita já fomos bombardeados por imagens e paisagens que nos fazem imaginar e possivelmente querer visitar 0 destino apresentado. Quando o espaço imaginado é vivido os sentimentos

\footnotetext{
${ }^{4}$ Inscrições na rocha em baixo relevo. Consideradas na arqueologia como componentes da arte rupestre, já que não são incisões naturais.
} 
envolvidos revelarão menor ou maior afetividade com esse espaço, sentimentos que serão suficientes em si para pensarmos no conceito de lugar.

Parece-me estar nessa relação profunda do individuo com os espaços vividos, possibilitado pela experiência e condicionado pelo imaginário a amálgama que delineia o fenômeno turístico no sítio arqueológico Bisnau.

Para isso, serão trabalhados os conceitos de espaço e lugar numa perspectiva que quando o espaço é vivido com intensidade, quando se estabelecem vínculos e sentimentos entre os homens e os espaços estes se transformam em lugares para aqueles que o tem para si.

Na relação estabelecida entre a experiência nos espaços permeada pelo imaginário poderemos recortar o espaço turístico, pensando que a partir dessa definição as estratégias para o incremento do fazer turismo no sítio arqueológico Bisnau tem uma primeira base. Os relatos coletados em entrevistas foram o meio para se chegar na realidade vivida, nas experiências estabelecidas e no entendimento dessa realidade percebida.

A pesquisa aqui proposta partiu em grande parte da minha bagagem como arqueólogo, na mesma medida, enquanto morador de anos da cidade de FormosaGO, o turismo arqueológico realizado aí, propiciado principalmente pelos sítios Bisnau e Toca da Onça revelavam em mim questionamentos acerca dessa atividade nesses espaços, até então entendidos como lócus de memória das populações que viveram na região pelos últimos dez mil anos e, no presente, praticado por arqueólogos e outros cientistas que procuram neles entender melhor nossa história.

No começo, as reflexões acerca do turismo nos sítios arqueológicos de Formosa-GO tomavam contornos basicamente de preocupação com a proteção e preservação desse patrimônio. A infraestrutura para receber os visitantes era precária e ainda é nos dias atuais. Apesar de existir incentivo para que a visitação se realize, além de acontecer a promoção dos sítios como um bem turístico e de valor histórico para o município, estes apresentam pouca capacidade estrutural de receber visitantes e mais importante que isso dar suporte para que a experiência ocorra de maneira 
integrada entre a liberdade dos indivíduos que visitam e a valorização do patrimônio e da comunidade circunvizinha aos atrativos.

Anos depois, já inserido nesse programa de pós- graduação em turismo (CET/UnB) passei a ter contato com uma série de conceitos e definições que revelavam a cada dia o que é esse fenômeno. Tal qual o tamanho do universo parece-me ser as possibilidades de pensar em turismo, por suas facetas, econômicas, educacionais, culturais entre muitas outras, podemos levantar questionamentos acerca do tema. $O$ tempo passou como passa pra todos, assim como para todos a realidade é revelada, mas na mesma medida não é percebida de igual forma. Aproximamos-nos de certas coisas e não de outras.

Assim, fui mentalmente construindo o turismo no sítio arqueológico Bisnau. Primeiro, percebi que qualquer forma de turismo, ou qualquer ação deliberada ou não produz uma experiência. $E$ toda experiência constrói um conhecimento e proporciona uma mudança no conhecido. Entendi então que para realizar uma pesquisa tendo por tema o turismo arqueológico no sítio Bisnau esse conceito (Experiência) teria de ser levado em conta.

Observei também, que para fazer turismo partimos de desejos e vontades, ou seja, motivações criadas antes mesmo de efetuarmos em si o deslocamento ao espaço imaginado. Cria-se então um espaço ideal, onde as experiências que imaginamos sejam supridas na visita. Somos atravessados por imaginários que podem criar essa motivação. Queremos visitar uma praia deserta ou um resort badalado? Queremos aventura ou tranquilidade? A mídia turística nos dá as cartas, escolhemos e podemos visitar. O sítio arqueológico, por exemplo, revela várias possibilidades de discursos que o desvelam. Seria realmente um espaço milenar onde seus moradores mais antigos deixaram suas marcas no lajedo (Discurso cientifico) ou tais desenhos são obra de algum espécime extra terrícola? Dessa forma, acredito que o imaginário, criado por narrativas e estabelecido através dos tempos, influencia tanto na motivação quanto na experiência turística. Imaginário, portanto, também é um conceito importante na pesquisa. 
O imaginário, enquanto motor que realiza o deslocamento turístico indica duas ações: A tomada de consciência acerca de um destino e o próprio movimento que acontece para que a visitação seja realizada. A primeira ação acontece de maneira ideal, no entanto, a segunda ação - deslocamento turístico - necessita de fisicalidade para que estabeleça. O movimento entre um espaço geográfico e outro só se realiza através desse mesmo espaço. Levanta-se a necessidade de pensar turismo fundamentalmente pela fisicalidade que the é conexa. Então, os conceitos de espaço e lugar também devem ser considerados.

Mas como as experiências existem? De que forma imaginários se estabelecem e por quem são compartilhados? Como são criados os espaços e os lugares?

Tudo isso existe e continuará a existir enquanto houver humanidade. Somente pelo homem e suas relações com outros indivíduos na terra que as experiências acontecem, os imaginários são compartilhados e lugares e espaços são construídos.

No próximo capítulo iremos discorrer acerca dos macro temas que estarão envolvidos nessa dissertação: o turismo e a arqueologia. Serão apresentados os objetos de interesse nas pesquisas arqueológicas, algumas de suas teorias e conceitos, pesquisas no âmbito dessa disciplina desenvolvidas principalmente na região centro-oeste do país, bem como situar e descrever o lócus em que essa pesquisa procura revelar seus questionamentos acerca do seu uso turístico. O sítio arqueológico Bisnau. Ainda nesse capítulo são trabalhados os principais pensamentos e campos de investigação em turismo, as influencias das teorias positivistas, marxistas e da fenomenologia nos estudos desse campo cientifico e o entendimento que elas não são excludentes, uma vez revelada a complexidade do fenômeno turismo impetrando às suas análises a multidisplinaridade e eu diria também uma multiteoricidade. Concluímos esse capitulo demostrando as relações entre essas duas áreas no campo do saber e suas interfaces na prática do turismo arqueológico. 
O capitulo 3 apresenta os dois principais conceitos trabalhados nessa dissertação. Imaginário e experiência. Estes serão fundamentais para entender a prática dos diferentes espaços dentro de uma visitação ao sítio arqueológico Bisnau. Como o imaginário influencia nas diversas experiências durante esta viagem e como essa experiência transforma os sujeitos que vivenciam e os espaços vivenciados.

A experiência turística acontece num espaço delimitado geograficamente e compreende a saída do seu lugar habitual, o trajeto de ida, o espaço - com todo seu conteúdo imaginado - o qual vai vivenciar e o caminho de volta ao seu espaço cotidiano. Essa experiência direta dos homens no mundo se estabelece na prática dos espaços e lugares que nos revelam em si as possiblidade de aludirmos um espaço turístico, para a visitação do sítio arqueológico Bisnau. O desvelamento dos lugares a partir da prática dos espaços é possível pelas experiências do homem no mundo influenciadas pelos imaginários e, que são externadas, em parte, nos relatos e narrativas dessas experiências.

Assim, o capitulo 5 apresenta entrevistas realizadas com 3 grupos de dois indivíduos cada, sendo um desses grupos composto pela comunidade vizinha ao sítio. O capítulo subsequente expõe como se procurou observar nas entrevistas captadas em áudio e vídeo, algumas expressões - verbais ou corporais - que revelassem algum envolvimento entre as pessoas e os espaços visitados, entendendo que nesse movimento, os espaços experimentados em profundidade são transformados em lugares. 


\section{BAGAGEM DE MÃO: APARATOS BÁSICOS PARA A VIAGEM}

\subsection{Arqueologia}

A arqueologia, como ciência, se dedica ao estudo do comportamento do homem e a relação do homem com o meio ambiente, através da análise da cultura material deixada pelas populações pretéritas no registro arqueológico. Os espaços onde estão armazenados esses registros são denominados sítios arqueológicos. Segundo Trigger (2004) a arqueologia "infere comportamento humano, e também ideias, a partir de materiais remanescentes do que pessoas fizeram e usaram, e do impacto físico de sua presença no meio ambiente" (TRIGGER, B.G. p.19 2004).

A Arqueologia tem como objeto de pesquisa imediato a cultura material de sociedades humanas (FUNARI, 2006). Esses vestígios podem ser entendidos como um texto e enquanto texto admite diferentes interpretações. Ainda para esse autor a arqueologia "estuda os sistemas socioculturais, sua estrutura, funcionamento e transformações com o decorrer do tempo a partir da totalidade material transformada e consumida pela sociedade" (2006)

Os dados arqueológicos são constituídos por todas as alterações no mundo material resultantes da ação humana, ou melhor, são os restos materiais da conduta humana. O seu conjunto constitui os chamados testemunhos arqueológicos (CHILD, 1987), que por sua vez compõe os sítios arqueológicos. São considerados sítios arqueológicos:

As jazidas de qualquer natureza, origem ou finalidade, que representem testemunhos da cultura; os sítios nos quais se encontram vestígios positivos de ocupação humana; os sítios identificados como cemitérios, sepulturas ou locais de pouso prolongado ou de aldeamento, e as inscrições rupestres ou locais que apresente outros vestígios de atividade humana pretérita" (IPHAN, 2014)

\footnotetext{
${ }^{5}$ Fonte: http://www.iphan.gov.br. Acesso em setembro de 2014.
} 
Os tipos de sítios arqueológicos são diversos, variando de acordo com os testemunhos em que são compostos. No Brasil, em especial no Centro-Oeste prevalecem os sítios líticos ${ }^{6}$, cerâmicos e de arte rupestre. As principais pesquisas realizadas nessa região confirmam isso, porém é bom deixar claro, que a resistência desses materiais frente ao tempo é maior se comparado a outros vestígios arqueológicos como o osso e a madeira por exemplo.

As pesquisas sistemáticas desenvolvidas na porção central do país se iniciaram na década de 70 sob a iniciativa do Instituto Goiano de Pré-história e Antropologia (IGPA) da até então Universidade Católica de Goiás e da Universidade Federal de Goiás (OLIVEIRA E VIANA, 2000), que levantaram e cadastraram mais de 700 sítios (BERTRAN, 1994).

As pesquisas acabaram por determinar uma datação - até o momento consensual por volta de 12.000 mil A.P $P^{7}$ para a ocupação humana das porções centrais do território brasileiro.

A porção sudoeste do atual estado de Goiás comporta o complexo arqueológico ${ }^{8}$ de Serranópolis e Caiapônia, que foi e ainda é fundamental para os estudos acerca da ocupação humana no cerrado, além disso, atualmente exerce importante papel sócio-educativo por meio de visitas guiadas. Para o estado, é ícone de turismo arqueológico. Os estudos na região apresentaram datas para ocupação humana de até 10.400 anos AP.

\footnotetext{
${ }^{6}$ São espaços onde são encontrados artefatos fabricados em rocha.

${ }^{7}$ Antes do Presente.

${ }^{8}$ Conjunto de sítios arqueológicos numa porção restrita e os espaços circundantes possíveis de serem vivenciados.
} 


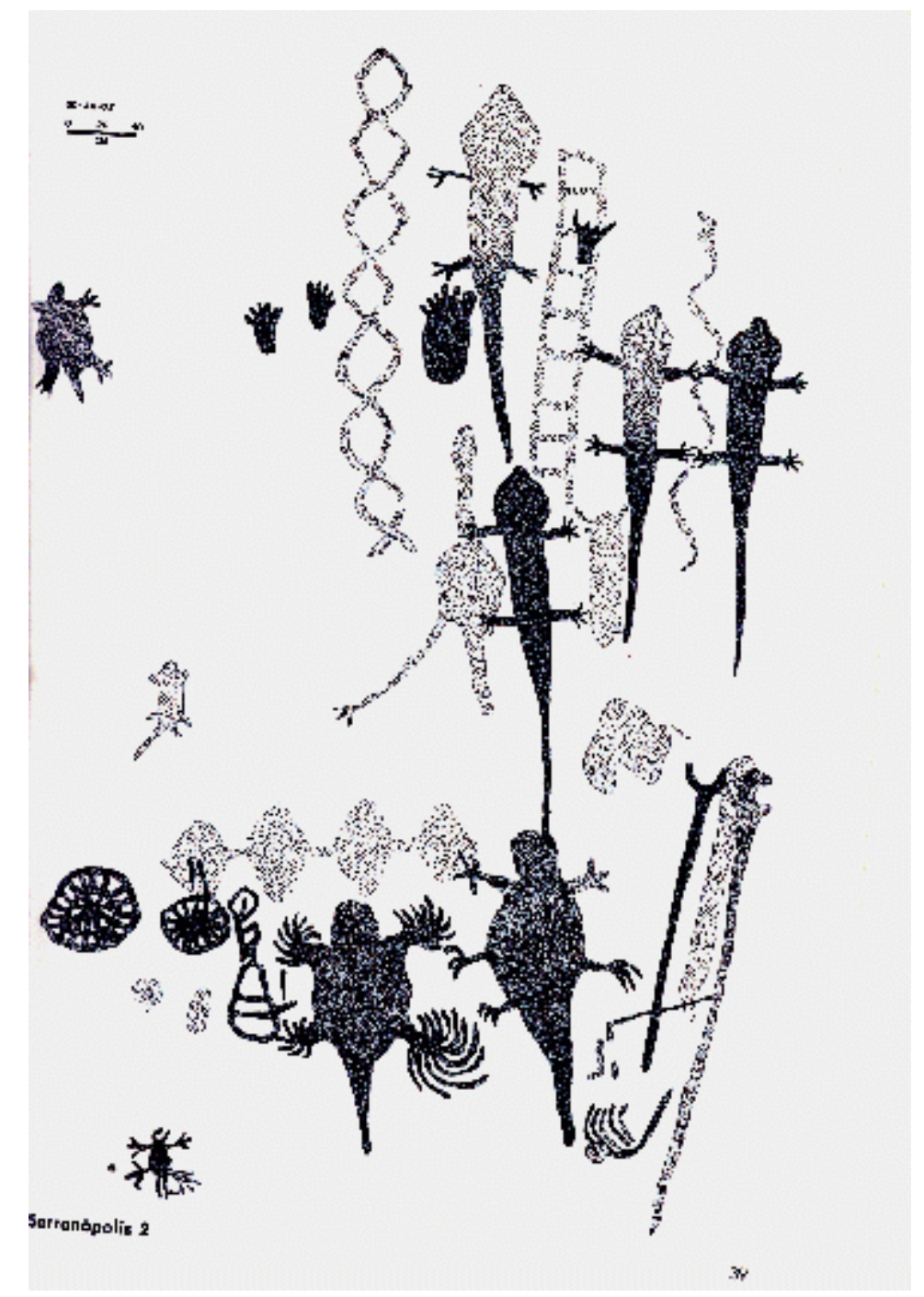

Figura 1: Motivos recorrentes em Serranópolis, Goiás

Vários motivos encontrados no município de Serranópolis são observados também em pinturas e gravuras de Formosa, como exposto mais a frente. Com exceção dos sáurios, as outras figuras estão presente inclusive no sítio arqueológico Bisnau. 


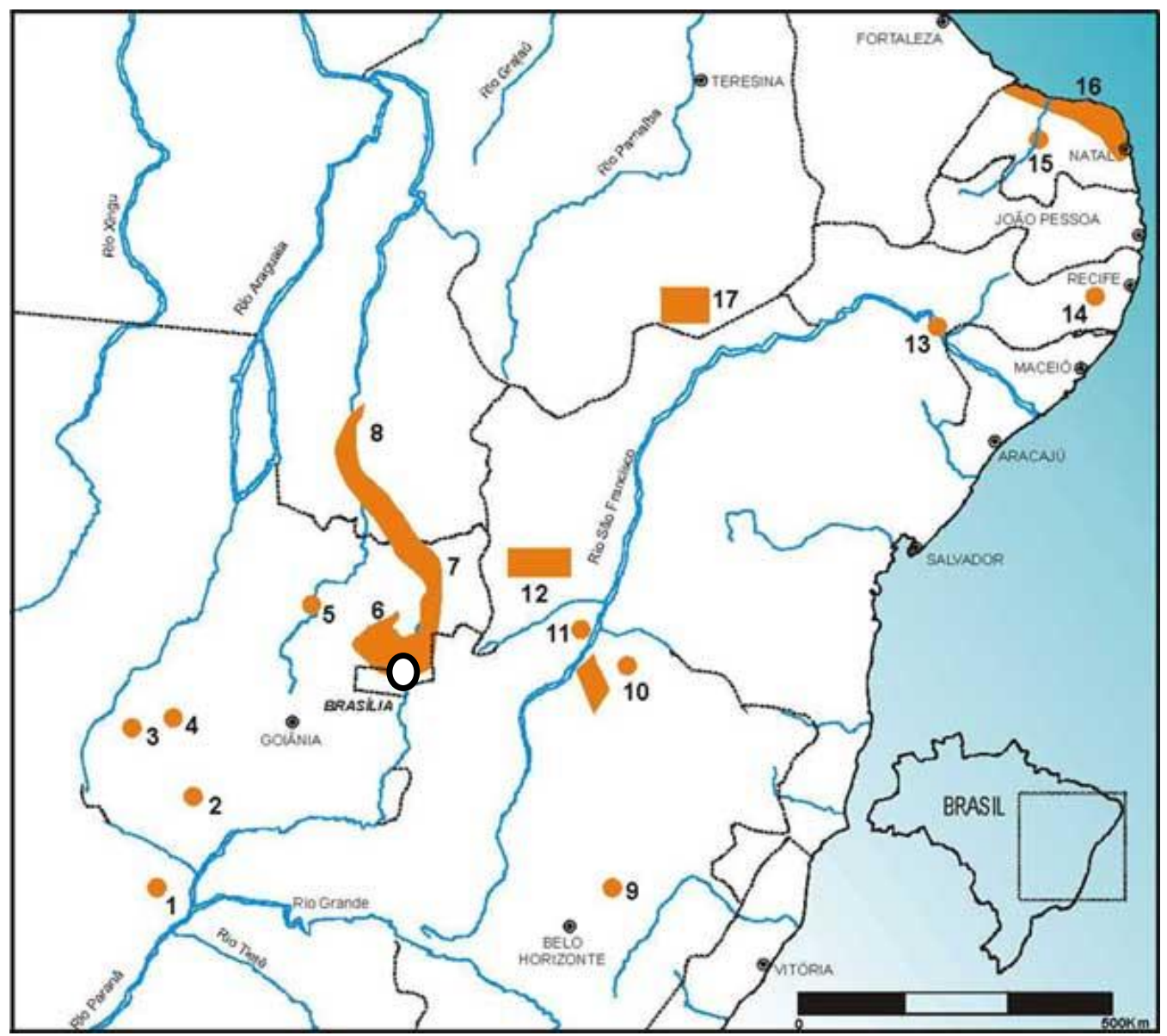

Figura 2: Sítios arqueológicos antigos nas savanas tropicais: 1. Alto Sucuriú, MS; 2. Serranópolis, 3. Rio do Peixe; 4. Caiapônia, 5. Uruaçu, 6. formadores do rio Tocantins, GO; 7. Rio Paranã, 8. UHE Serra da Mesa, TO; 9. Serra do Cipó, 10. Varzelândia, 11. Vale do Peruaçu, MG; 12. Serra Geral, BA; 13. Itaparica, 14. Bom Jardim, PE; 15. Rio Açu, 16. Litoral, RN; 17. São Raimundo Nonato, PI. Fonte: SCHMITZ (2003).

Observação: Circulo vazado à nordeste de Brasília indica a área abrangida nesta pesquisa.

Após a delimitação do quadrilátero Cruls $^{9}$ e a construção de Brasília, houveram na década de 90, pesquisas arqueológicas nesse novo território. Sob a coordenação do arqueólogo Dr. Eurico Miller, foram levantados diversos sítios, principalmente líticos e cerâmicos, nas cabeceiras do córrego Ipê, nas margens do ribeirão Ponte Alta, a oeste do Gama, e no córrego Melchior em Taguatinga, além de sítios ao longo do rio Descoberto (BERTRAN, 1994).

\footnotetext{
${ }^{9}$ Ainda no século XIX se estabeleceu o desejo da mudança da sede do governo para o Planalto Central, assim, em 1892, Floriano Peixoto nomeia a Comissão Exploradora do Planalto Central do Brasil, que ficou sendo conhecida por Missão Cruls, já que tinha como chefe, o astrônomo de nome Luiz Cruls. Após a demarcação dos $14.400 \mathrm{Km}^{2}$ de área na porção central do território nacional, foi criado oficialmente o Distrito Federal.
} 
O acervo arqueológico do entorno do Distrito Federal também mostra a riqueza e a diversidade histórico-cultural do Planalto Central brasileiro. No município de Planaltina de Goiás efetuaram-se pesquisas no final da década de 70 e inicio da década de 80 onde nas margens do córrego rico foram escavadas e coletadas mais de 4 mil peças em uma oficina lítica (MARTINS, 1983). Ainda na abrangência desse município, Margarida Andreatta pesquisou o sítio Barreiro que apresentou data de 10.600 anos A.P.

Outro importante complexo arqueológico situa-se nos limites do município de Formosa-Goiás. Além de sítios líticos e cerâmicos há a predominância dos sítios que apresentam arte rupestre. Segundo Pedro Schmitz e Altair Barbosa cadastram-se ali cerca de 29 grutas (1984), e em sete desses abrigos, tetos e paredes apresentam pinturas monocrômicas com a prevalência de motivos geométricos (BERTRAN, 1994).

Os motivos geométricos compõem a denominada tradição geométrica, que é uma das sete tradições rupestres definidas para o território brasileiro além da região amazônica que apresenta diversas tradições (PROUS, 1992). Essa tradição apresenta, na maioria dos seus motivos, figuras geométricas, círculos, linhas, pontos, e em menor número, algumas figuras humanas e de animais podem aparecer.

As gravuras na tradição geométrica são frequentemente polidas ${ }^{10}$, e nota-se a grande predominância de "cupuliformes" (depressões hemisféricas ou em calota de esfera). Segundo André Prous (1992) nos raros casos onde aparece uma representação biomorfa, parece tratar-se de sáurios ou homens.

\footnotetext{
${ }^{10}$ Outra técnica utilizada para realizar esse tipo de tarefa e o picoteamento que acontece através da percussão repetida de uma superfície por um batedor, o que provoca se esfarinhamento, com consecutiva abrasão progressiva [...] o polimento é obtido esfregando-se uma pesra sobre um polidor pelo menos tão duro quanto ela, com a ajuda de um abrasivo (areia) e de frequentes lavagens de água (PROUS, 1992).
} 

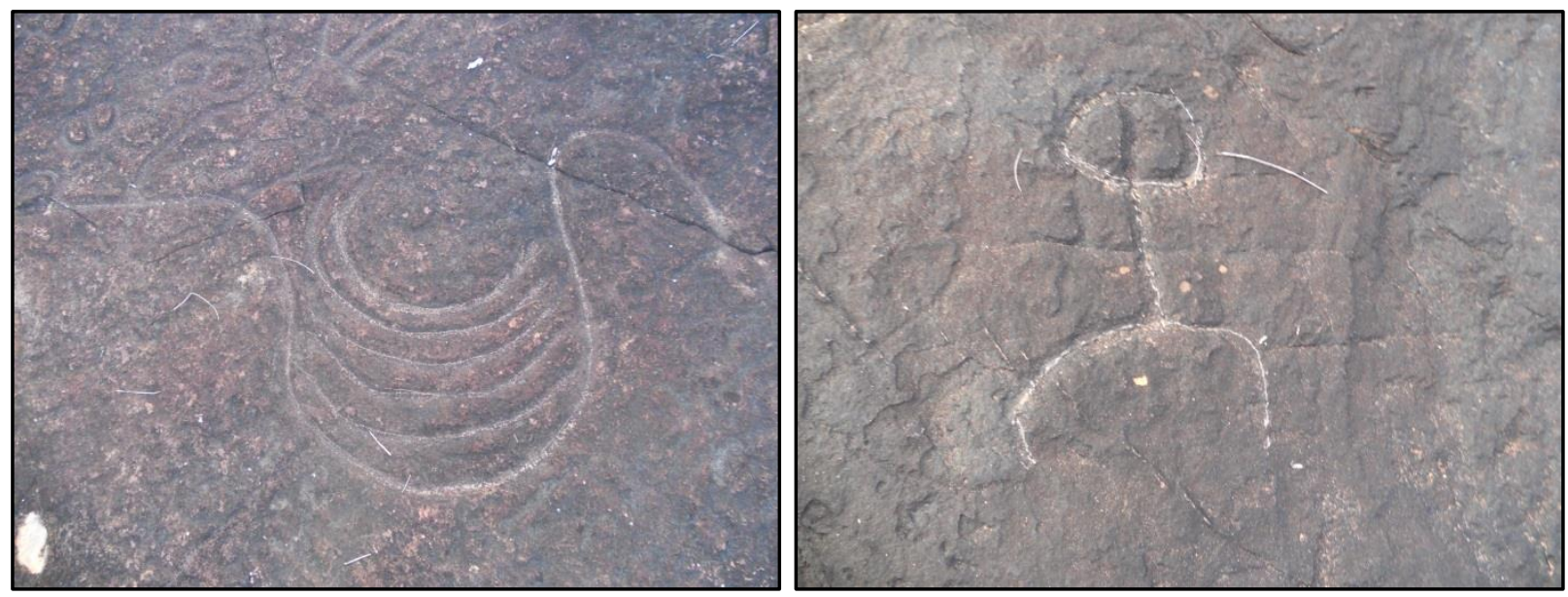

Foto 3: Cupuniformes do sítio arqueológico Foto 4: Possível representação humana. Bisnau.

O uso de tradições e fases é herança dos métodos e teorias utilizadas nas principais pesquisas no Centro-Oeste. À época do inicio das pesquisas nessa região a corrente teórica histórico-culturalista predominava nos ensaios e relatórios. O uso dessas tradições firmadas em solo histórico-culturalista, portanto, tinham por objetivo compreender e interpretar a cultura material através do método comparativo, dando ênfase nas semelhanças tecnológicas e morfológicas a fim de criar tipologias e seriações que comporiam as fases e tradições (OLIVEIRA E VIANA, 2000).

Além das tradições rupestres, os outros dois grandes grupos de testemunhos arqueológicos - cerâmico e lítico - também foram determinados e articulados dentro de fases e tradições. As principais tradições cerâmicas determinadas para o planalto central são Una, Aratu, Uru e Tupiguarani. (WÜST, 1990; OLIVEIRA E VIANA, 2000).

Já as tradições líticas, são divididas principalmente em Itaparica com datações por volta de 10.000 anos A.P (FOGAÇA, 2001; OLIVEIRA E VIANA, 2000) e Serranópolis com datações aproximadas de 9.000 a 6.000 anos A.P (SCHMITZ et al. 1989). 


\subsubsection{Sitio Bisnau}

O sítio arqueológico Bisnau está localizado a aproximadamente $45 \mathrm{~km}$ da cidade de Formosa - GO, ainda nos limites desse município. O relevo da região apresenta terrenos planos, baixadas e extensos chapadões, a vegetação predominante é o cerrado. A região é conhecida como berço das águas portando a nascente de rios que compõe as bacias do São Francisco, Tocantins e do Prata. As chapadas, dotadas por diversas grutas de variado tamanho e forma, serviram de abrigo a essas populações, fato constatado pelas pesquisas arqueológicas anteriores ${ }^{11}$. Essa diversidade natural propiciou o estabelecimento de populações pré-históricas e garantiu os recursos básicos para manutenção dessa estada.

O sítio arqueológico Bisnau, objeto de estudo dessa pesquisa é composto por um lajedo a céu aberto e caracteriza-se pela presença de petróglifos. Como citado acima, os motivos prevalentes na região são os geométricos, sendo que Bisnau não difere dessa constatação. Os petróglifos ou gravuras estão inseridos dentro do conceito de arte rupestre que é entendida por André Prous, (1992) como sendo "todas as inscrições deixadas pelo homem em suportes fixos de pedra". Os petróglifos, portanto, são inscrições em baixo relevo que foram confeccionadas a partir da fricção de determinada rocha, num suporte, também rochoso.

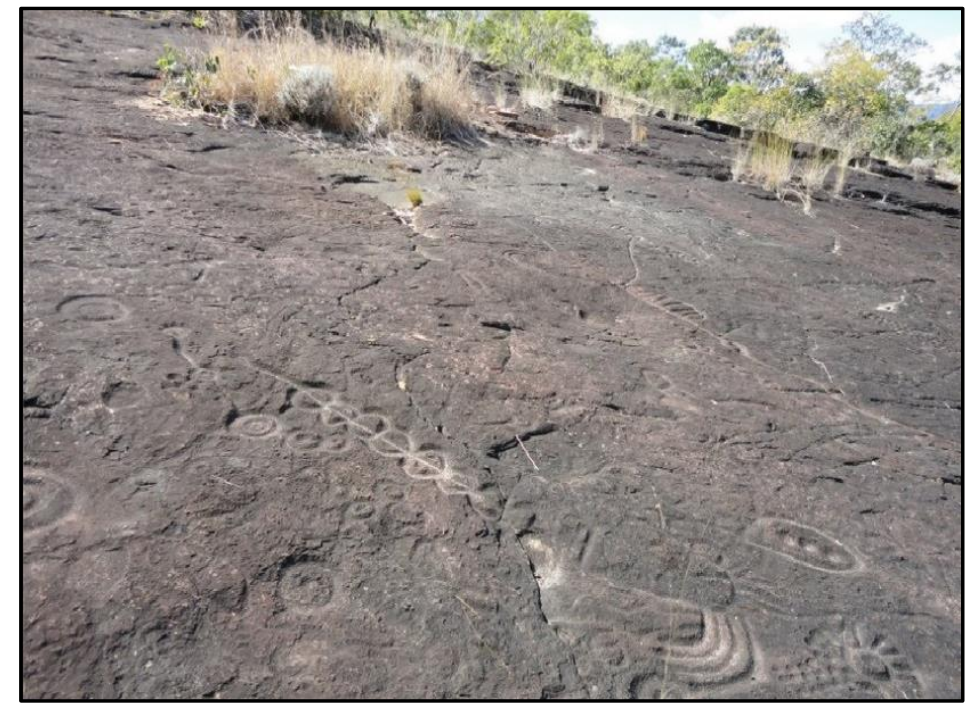

Foto 5: Evidenciação de vários sulcos presentes na rocha.

\footnotetext{
${ }^{11}$ Mendonça de Souza, A.A.C. et al., 1979. Projeto da Bacia do Paraná II. Museu Antropológico, UFG-Goiânia.
} 


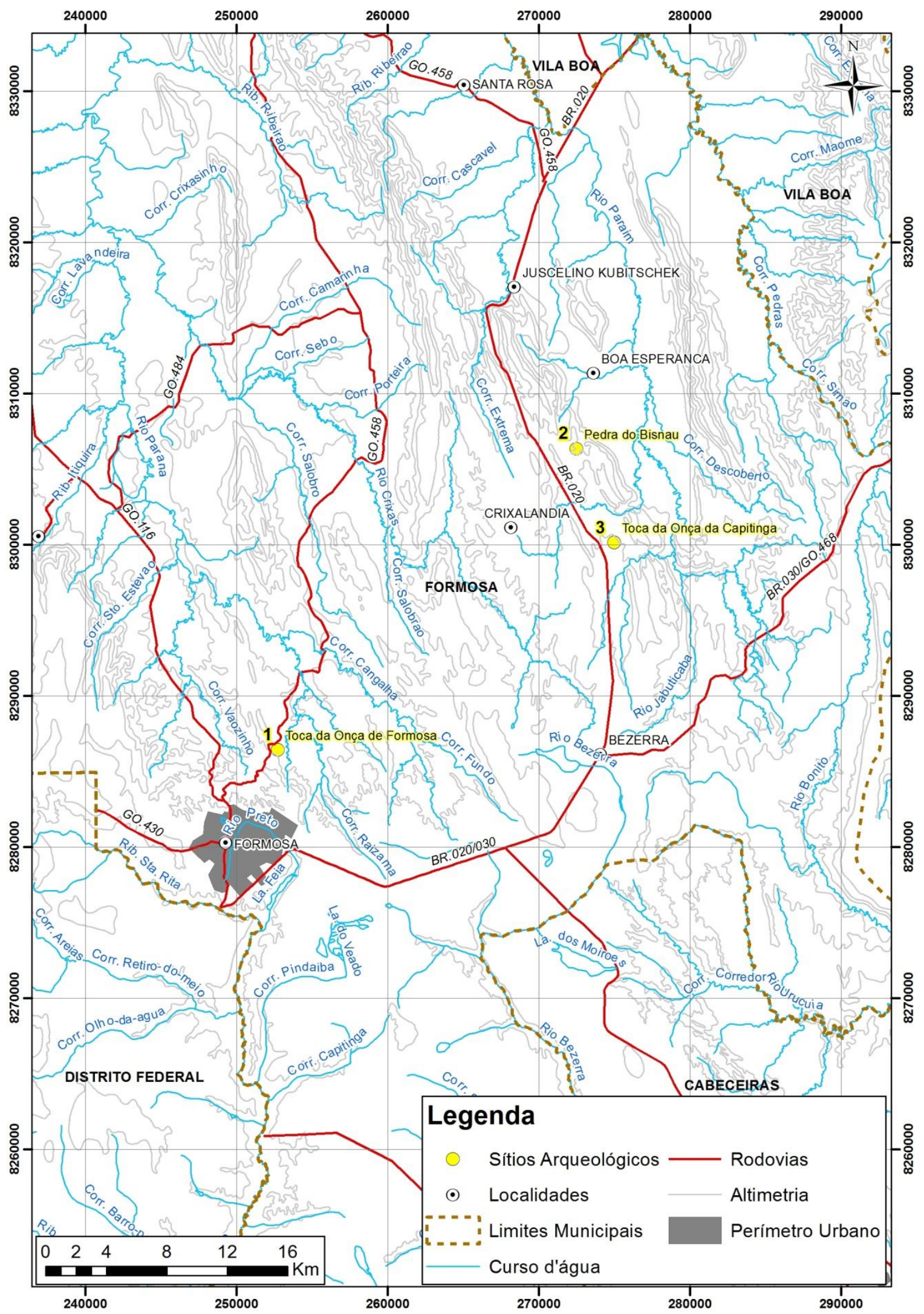

Figura 3: Localização dos sítios arqueológicos Bisnau, Toca da Onça da Capetinga e Toca da Onça de Formosa, todos inseridos nos limites do município de Formosa-Goiás. 


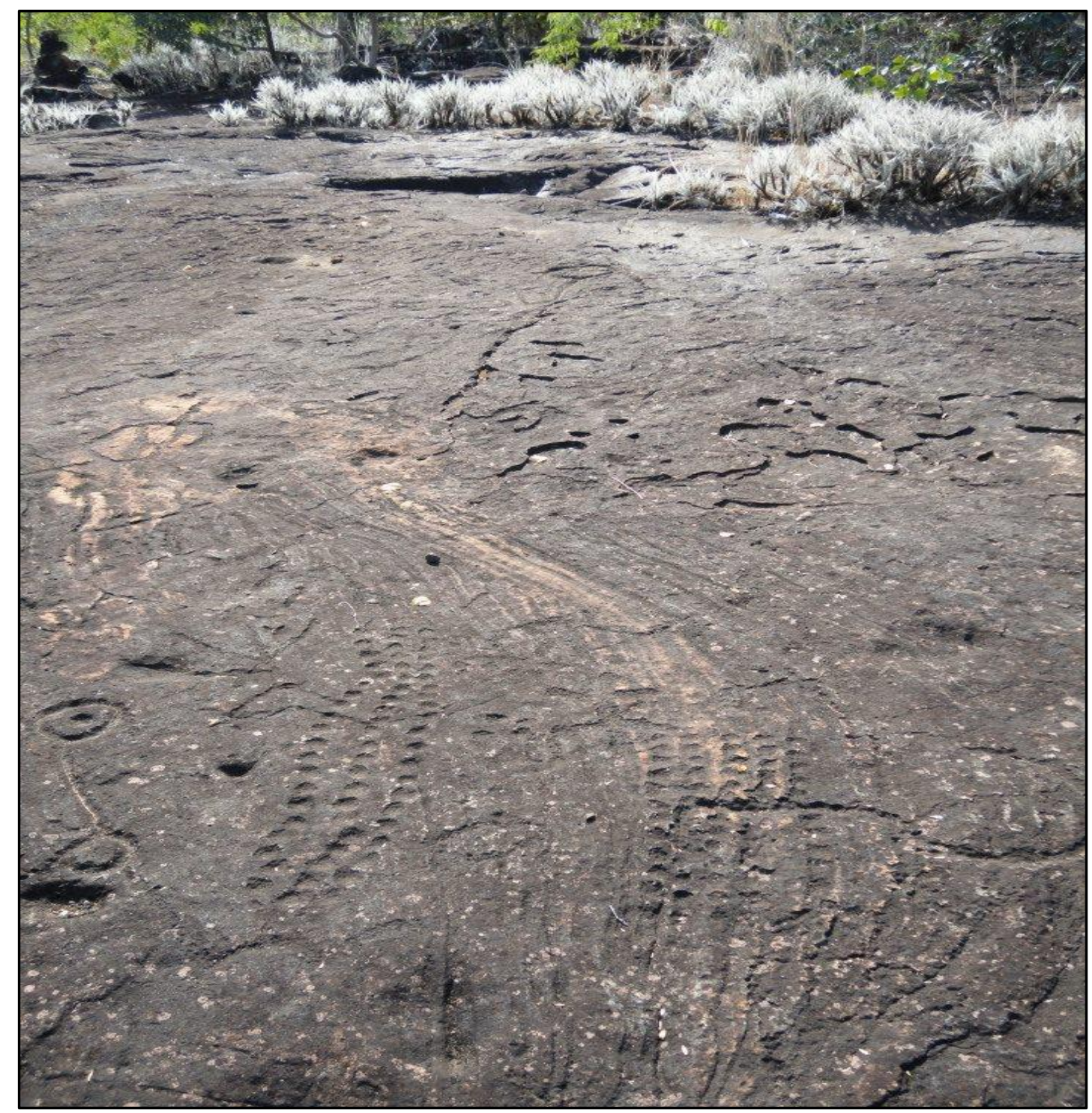

Foto 6: Sequência de pontos incisos na rocha e círculos unidos por uma linha. ${ }^{12}$ Foto: Hugo Emanuel.

De acordo com o Cadastro Nacional de Sítios Arqueológicos (IPHAN, 2015), foi diagnosticada, ainda na década de 70 , uma oficina lítica ${ }^{13}$ disposta nas proximidades do rio Bisnau em Formosa- Goiás, sendo o sítio denominado com este topônimo.

\footnotetext{
${ }^{12}$ A tempos ouvi a seguinte interpretação acerca da sequência de pontos: "Quando a pedra era mole passaram ali carros de boi que deixaram marcados suas rodas no lajedo". Fonte: Conversa informal com o senhor Pedro, 2013.

${ }^{13}$ A ficha de cadastro do citado sítio arqueológico não apresenta informações claras acerca de sua localização, informando apenas que insere-se em compartimento de encosta, próximo ao Rio Bisnau nos limites do município de Formosa- Goiás.
} 
Uma oficina lítica consiste num espaço de atividade especifica, no caso, um local para a confecção de instrumentos de rocha. A diversidade de registros arqueológicos sustenta, quando aliado a demais componentes arqueológicos e ambientais a possibilidade da existência de um sistema regional de assentamento (MORAIS, 1999).

O Cadastro Nacional de Sítios Arqueológicos (CNSA/IPHAN, 2015) apresenta em seus registros cerca de 35 sítios $^{14}$ entre cerâmicos, líticos e rupestres para o município de Formosa-Goiás (IPHAN, 2015), que em sua maioria foram pouco estudados e vem sendo subutilizados na feitura do seu papel sócio-educacional e turístico.

Os motivos recorrentes no sítio arqueológico Bisnau são pertencentes a tradição geométrica. André Prous (1992) reconhece que esta tradição pode ser dividida em duas subdivisões: uma meridional e central (Santa Catarina, Paraná, São Paulo e Mato Grosso) e outra setentrional que Niéde Guidon denominou "subtradição Itacoatiara" que se estenderia desde o Ceará a Paraíba e talvez Goiás. (PROUS, 1992).

O sítio arqueológico Bisnau parece estar numa zona média entre as manifestações setentrionais e meridionais, ora seguindo parâmetros técnicos do primeiro, ora estilísticos de ambas as ocorrências.

Segundo Prous (1992) as ocorrências da subdivisão setentrional estão localizadas exclusivamente na proximidade de rios e cachoeiras, onde aproveitam o afloramento de rochas duras. Essas características também podem ser observadas no lajedo do sítio arqueológico Bisnau.

\footnotetext{
${ }^{14}$ http://portal.iphan.gov.br/portal/montaPaginaSGPA.do
} 
Entretanto, para esse sítio (Bisnau), e conforme as representações utilizadas por Prous (1992) observo também semelhanças nos traços com os motivos da subdivisão meridional, especificamente da Tradição litorânea conforme figuras abaixo:

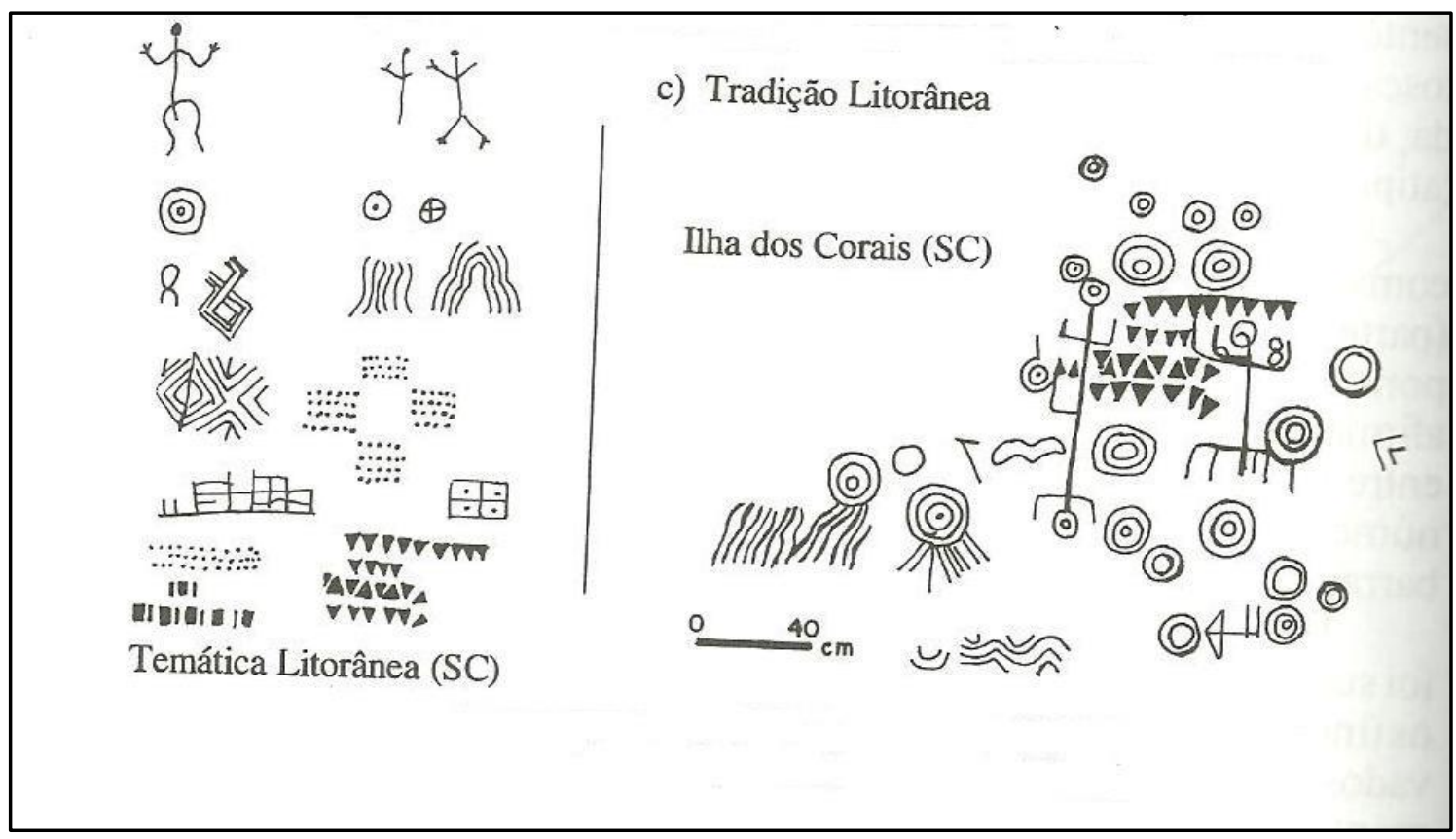

Figura 4: Motivos Recorrentes da Tradição Litorânea (SC). Fonte: PROUS (1992). 


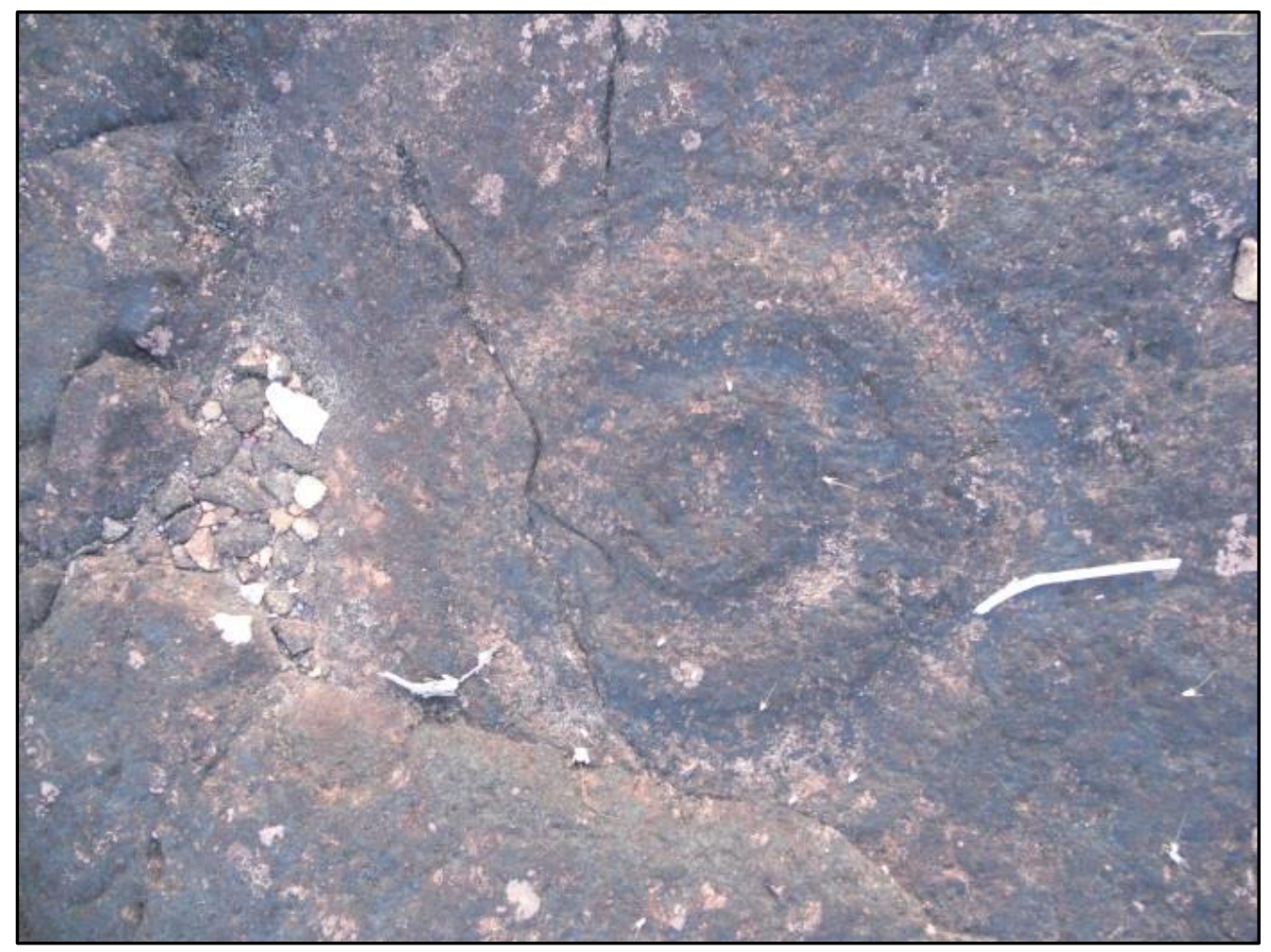

Foto 7: Motivos do sítio arqueológico Bisnau semelhantes a tradição Litorânea . Foto: Hugo Emanuel.

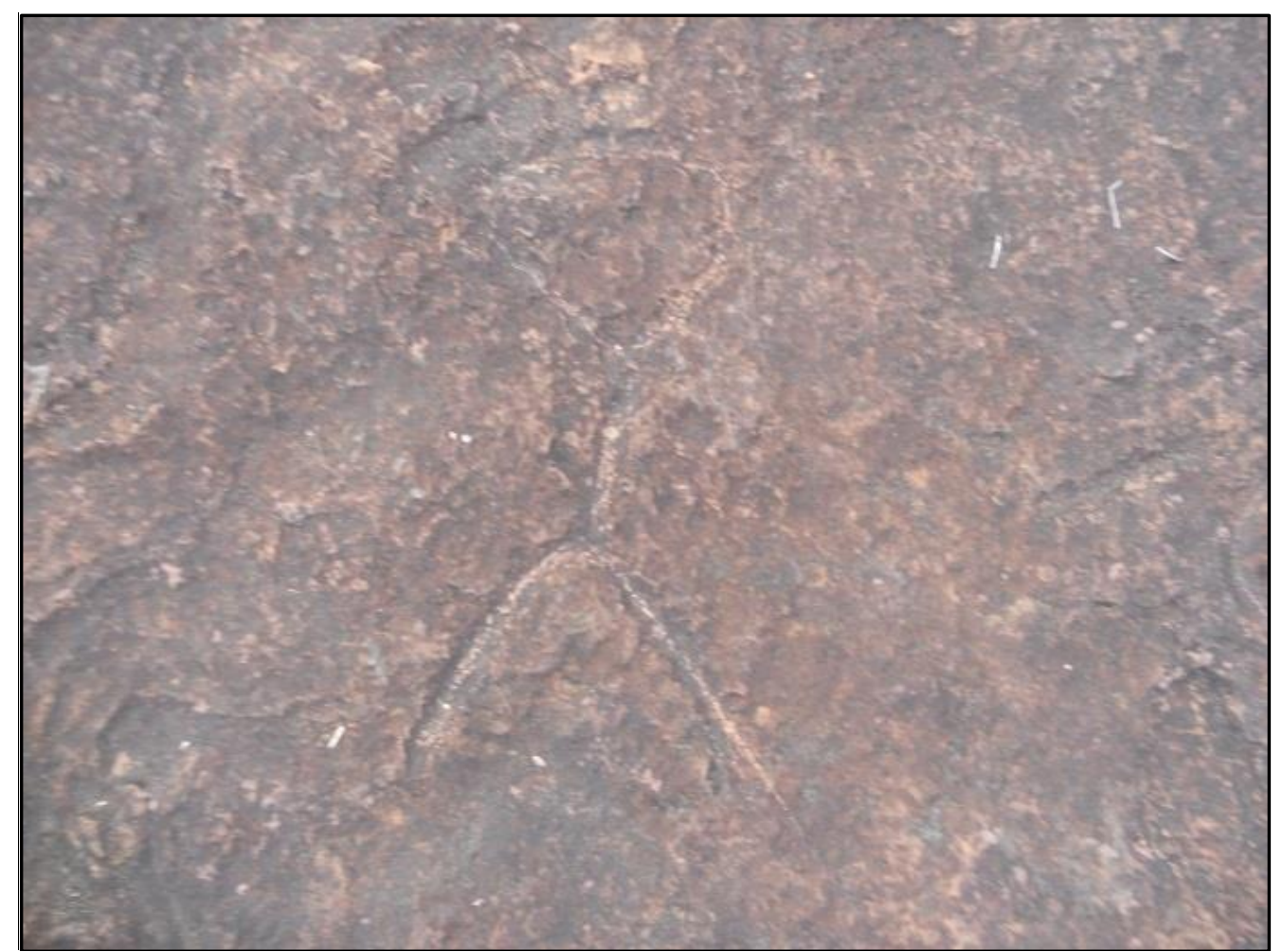

Foto 8: Motivos do sítio arqueológico Bisnau semelhantes a tradição Litorânea . Foto: Hugo Emanuel. Foto: Hugo Emanuel. 


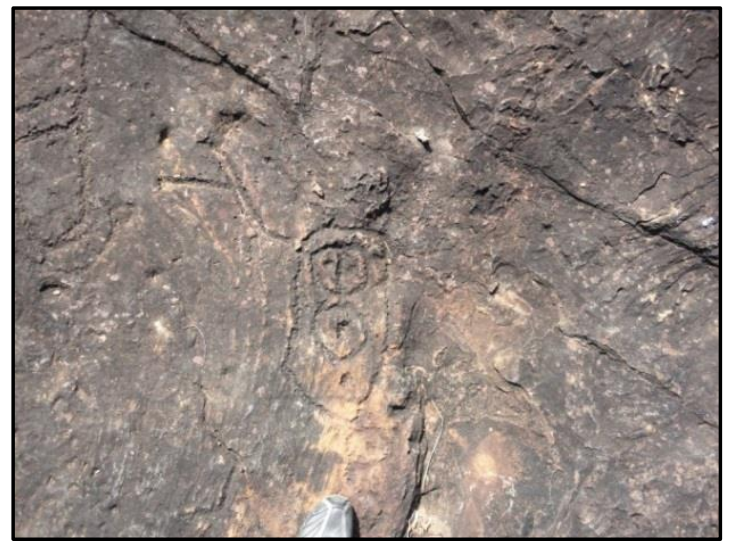

Foto 9: Motivos do sítio arqueológico Bisnau semelhantes a tradição geométrica nordestina observados na Pedra Lavrada no município de Ingá na Paraíba. Foto: Hugo Emanuel.

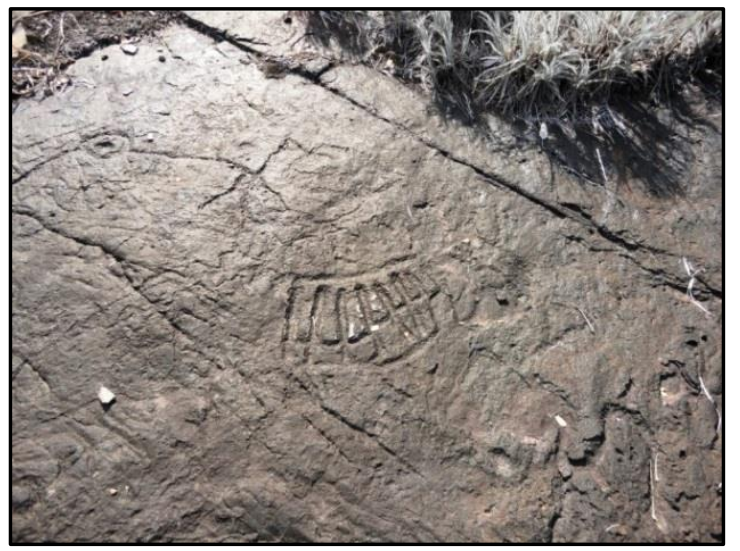

Foto 10: Motivos do sítio arqueológico Bisnau semelhantes a tradição geométrica nordestina observados na Pedra Lavrada no município de Ingá na Paraíba. Foto: Hugo Emanuel.

Além da grande quantidade de círculos concêntricos que apresenta o lajedo do sítio Bisnau, se assemelhando então as representações majoritárias da tradição Litorânea como expõe Prous, outros motivos também apresentam semelhanças nos seus traços, como, entre muitos outros, os círculos unidos por uma linha, como destacado na figura abaixo (Pedra Lavrada) e observados no sítio Bisnau conforme foto 11:

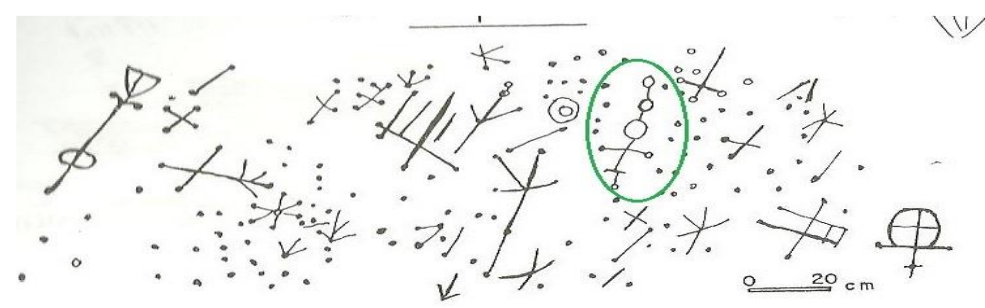

c) Pedra Lavrada (Picuí, PB)

d) Pedra Lavrada (Ingá, PB)

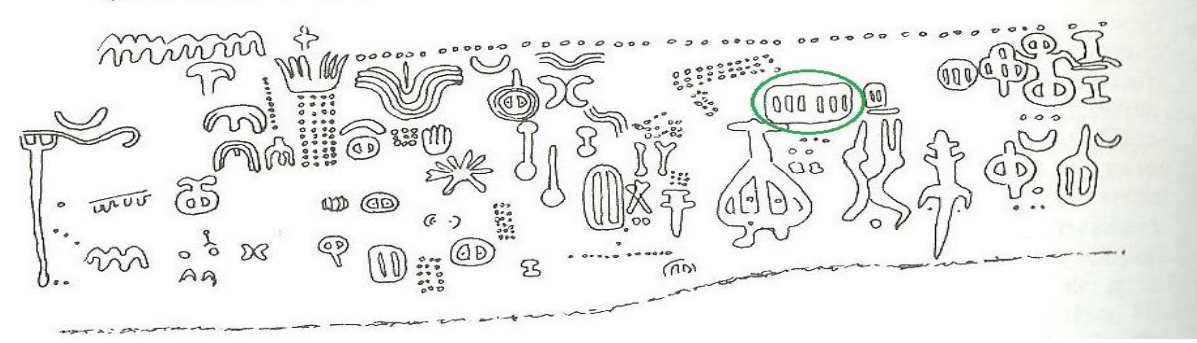

Figura 5: Motivos recorrentes da tradição Nordestina. Fonte: PROUS (1992). 


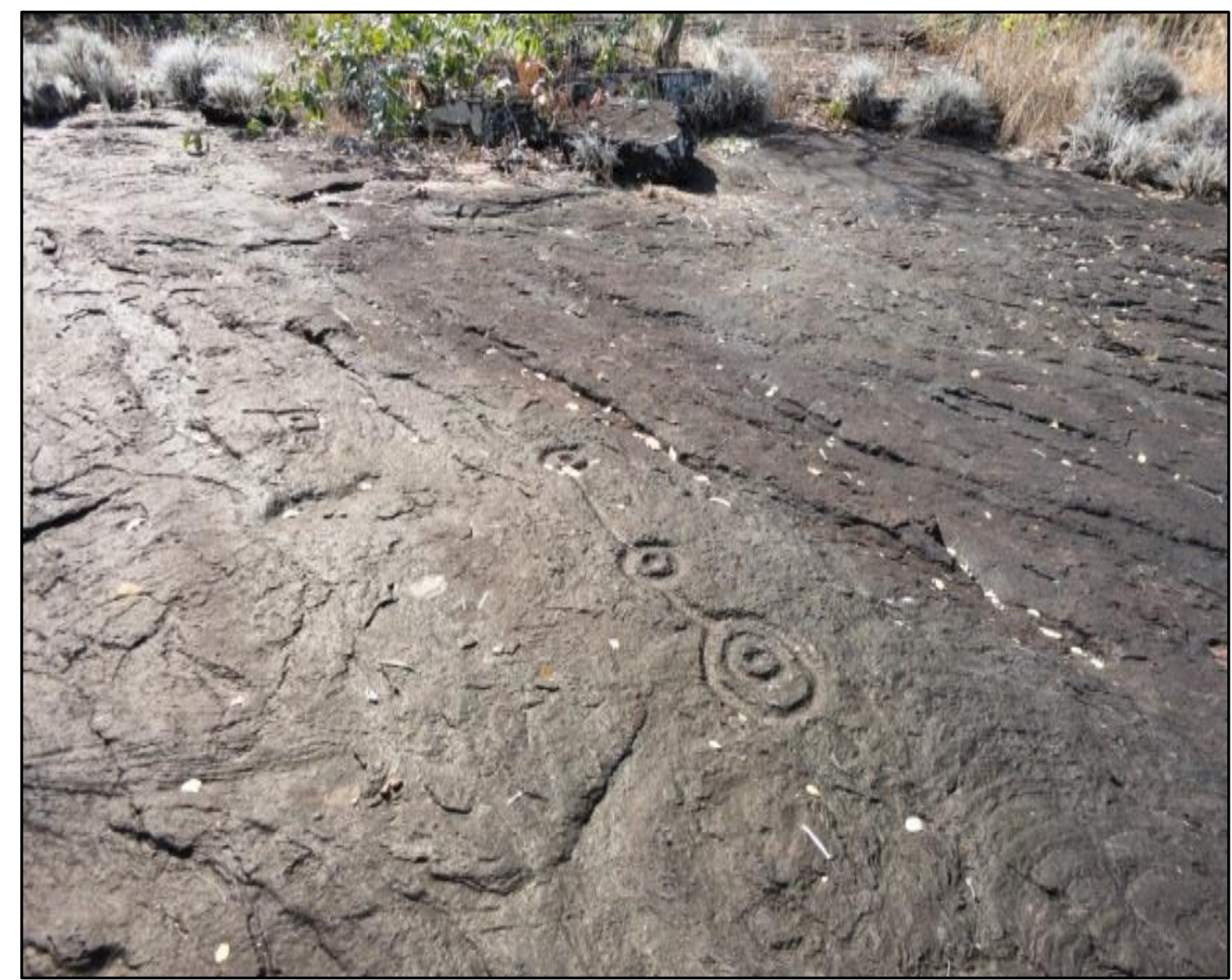

Foto 11: Grafismos do lajedo do Bisnau semelhante a representação destacada na figura da tradição nordestina e Pedra lavrada, município de Ingá na Paraíba. Foto Hugo Emanuel.

Dessa forma, os grafismos observados no lajedo do sítio arqueológico Bisnau possuem traços semelhantes a diversas outras representações espalhadas pelo Brasil, fato que levanta questões que necessitarão de mais pesquisas arqueológicas num futuro. A região em questão seria um corredor que permitiria o fluxo de pessoas e informações, gerando tamanha semelhança com outras inscrições encontradas no Brasil? Em virtude da utilização de círculos e linhas, comum a diversas representações pelo mundo, estes símbolos seriam inerentes às culturas humanas?

Além da similaridade observada nos motivos das gravuras rupestres desse sítio, o município de Formosa-GO apresenta também algumas aproximações do seu acervo de vestígios de pintura rupestre a diferentes outras tradições do território Nacional. 
Próximo ao Sítio Bisnau encontra-se o sítio Arqueológico Toca da Onça da Capetinga $^{15}$ que apresenta em seu interior diversas representações de pintura rupestre. Há predominância dos motivos geométricos, porém outras inscrições são observadas como os "biomorfos".

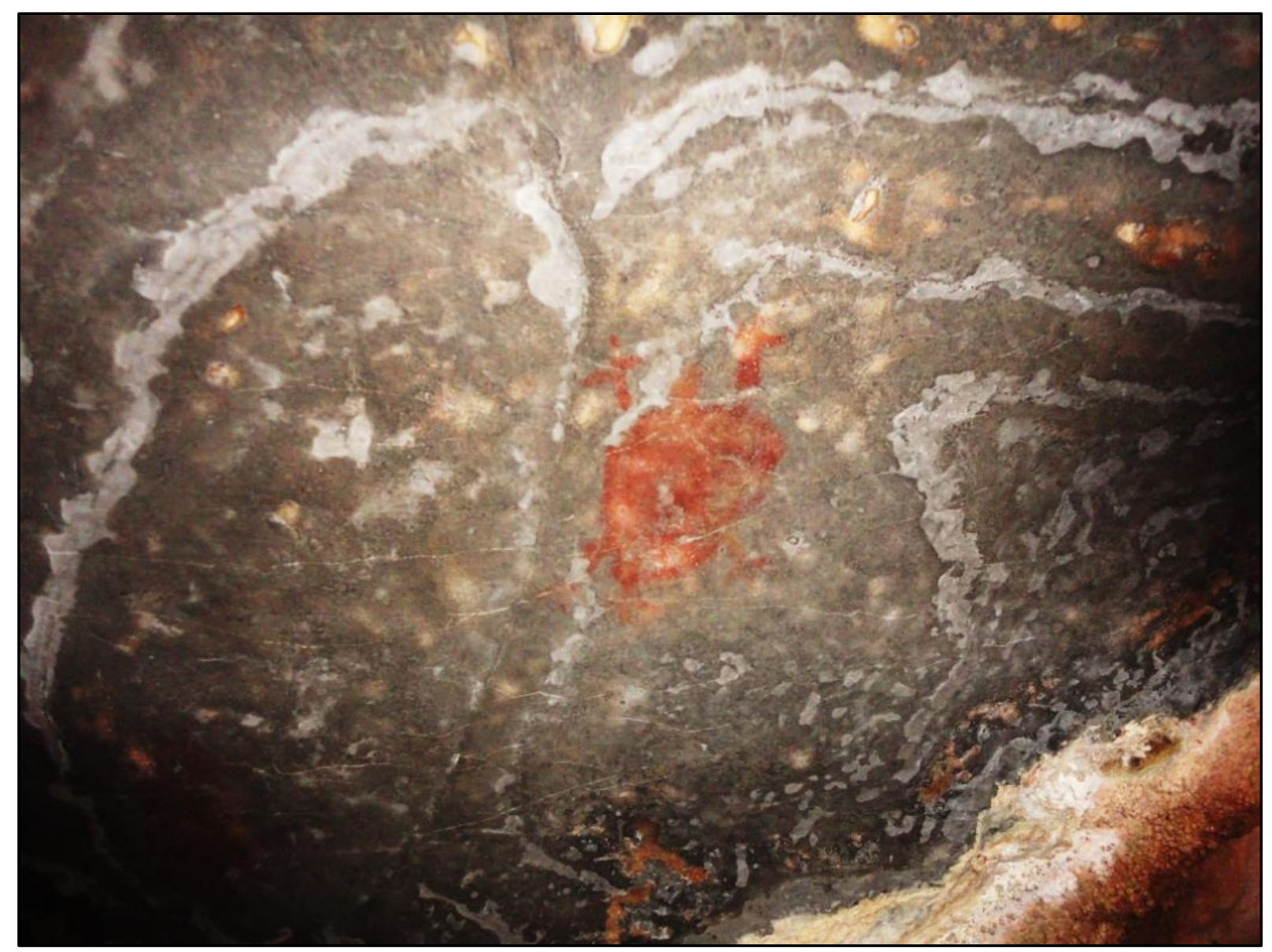

Foto 12: Desenho rupestre biomorfo. Toca da Onça da Capetinga, Formosa-Go. Foto: Hugo Emanuel.

Conforme figura a seguir, não distante dos dois sítios acima citados localiza-se o sítio arqueológicos Toca da Onça.

\footnotetext{
${ }^{15}$ Sítio inserido em ambiente de abrigo sob-rocha. Formação Calcária.
} 


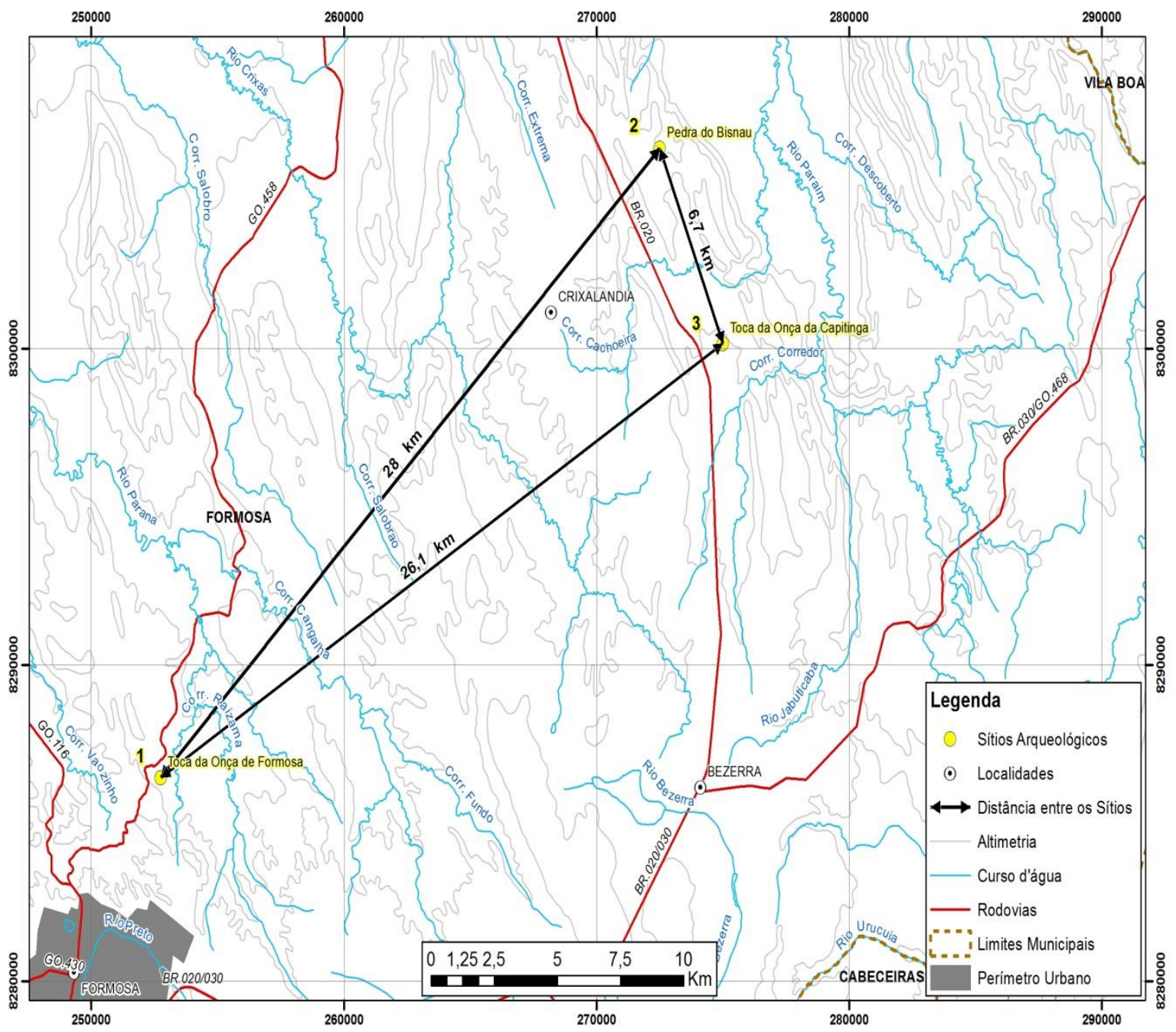

Figura 6: Distancia entre os sítios arqueológicos Binau, Toca da Onça da Capetinga e Toca da Onça de Formosa. O numeral 3 exposto na figura representa a pamonharia do Bisnau.

A Toca da Onça em Formosa é um sítio rupestre carregado de inscrições geométricas e está inserido em um abrigo sob-rocha calcária. Apesar da prevalência dos motivos geométricos, assim como os demais sítios da região este apresenta outras representações. Nesse sítio a presença de pés (!?), incita aproximações, também à tradição São Francisco. 


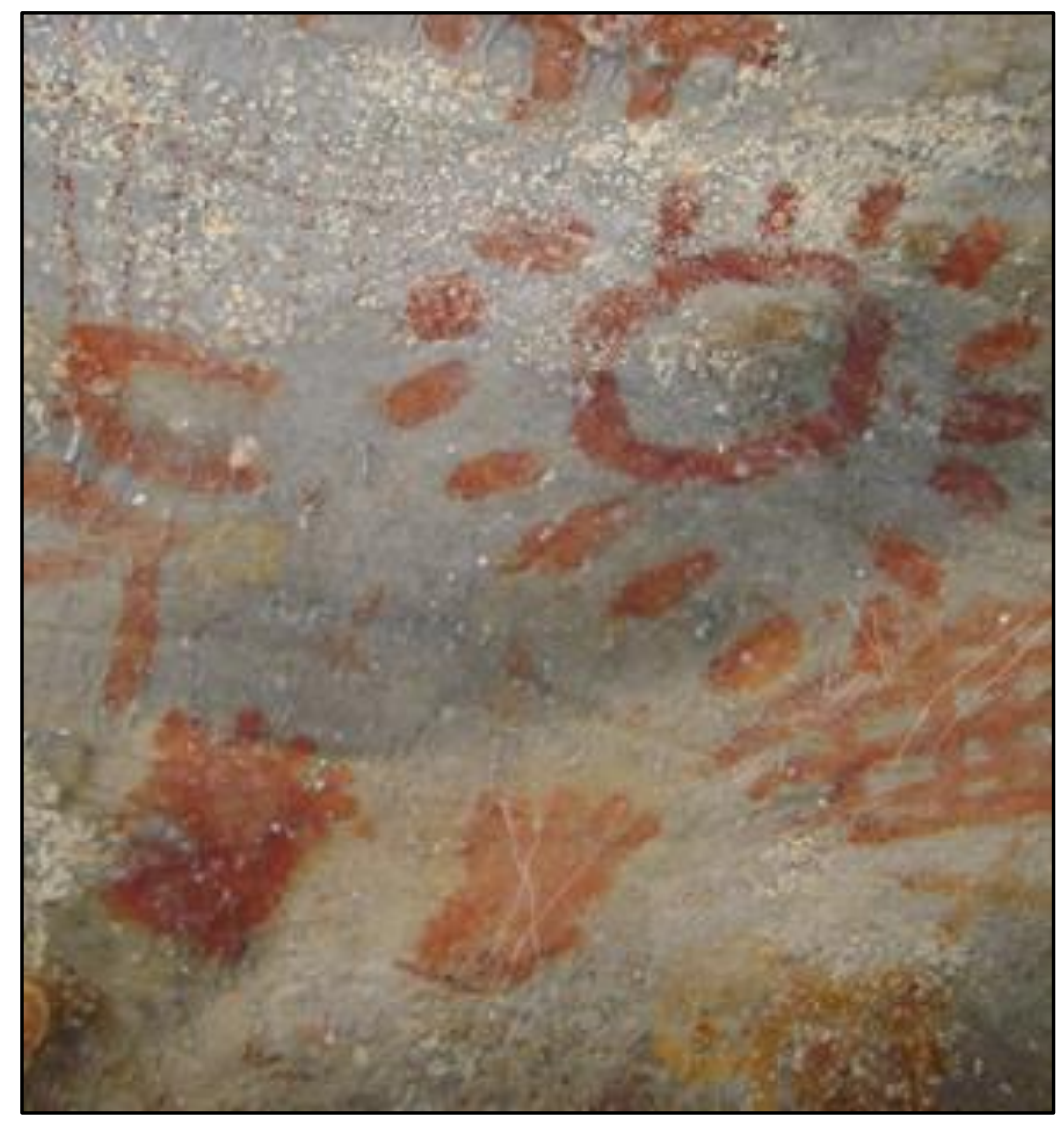

Foto 13: Pinturas do sítio Toca da Onça de Formosa.

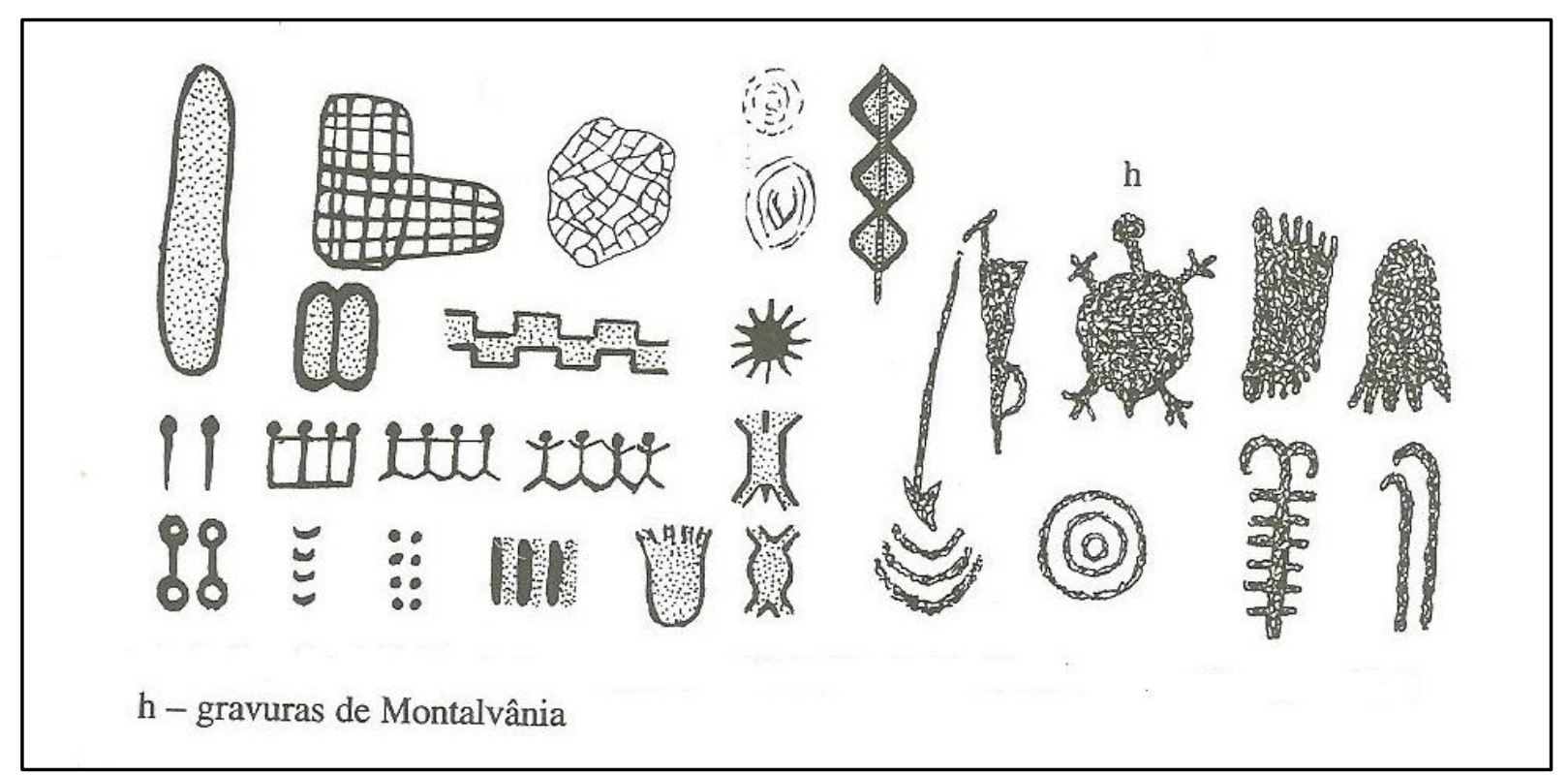

Figura 7: Motivos da tradição Nordeste. Fonte: Prous (1992)

Percebemos aqui grande semelhança com pinturas e gravuras dos sítios até agora citados no município de Formosa - Goiás. Os motivos observados do lado direito da figura 6, em Montalvânia, MG se assemelham com pinturas da Toca da Onça da 
Capetinga (foto 12) e Toca da Onça de Formosa (foto13), bem como alguns motivos do sítio Bisnau.

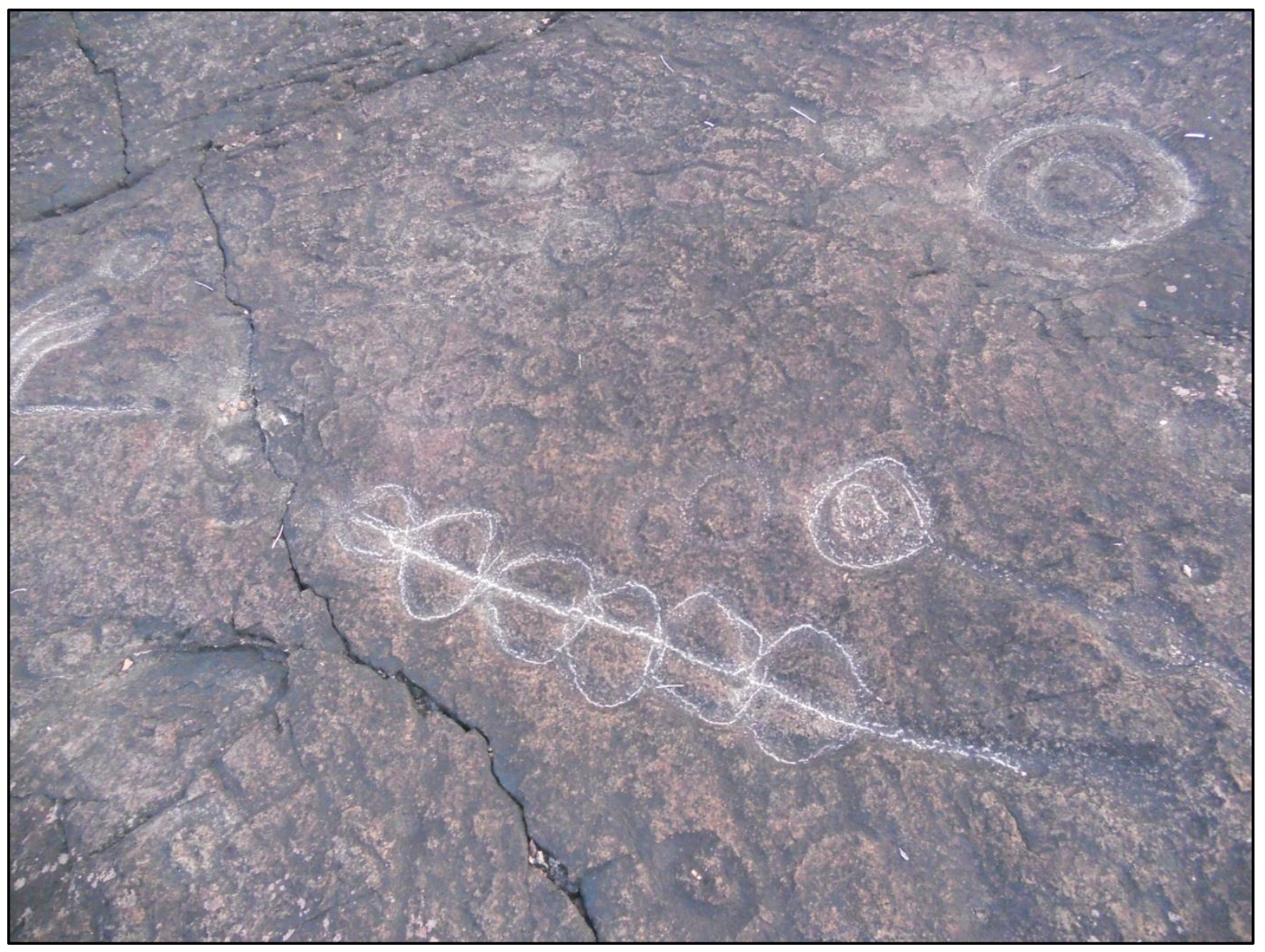

Foto 14: Gravuras do sítio Bisnau semelhante aos observados na figura 6.

O sentido que toma essas manifestações é variado dentro das diversas pesquisas realizadas pelo mundo, porém, é comum atribuir-se um valor mágico ou religioso a essas representações. Muito usual é a linha da "arqueoastronomia" que tenta verificar se certos grafismos não representariam fenômenos celestes. (PROUS, 1992). Essa interpretação pressuporia que estes grafismos representassem fenômenos celestes ou outros elementos do céu: estrelas, cometas e eventos astronômicos. Para outros autores, as figuras são expressões de viagens xamanísticas decorrentes da ingestão de drogas (GASPAR, 2003). 
Annete Emperaire ao dizer sobre o estudo rupestre na arqueologia expunha que aparentemente esse campo é mais fácil de ser estudado, os vestígios são tão visíveis que não necessitam de escavação, e tão mudos que aceitam qualquer interpretação, mas acrescenta que este é o capítulo mais complexo e que suscita maiores erros.

Quando a autora declara que tais representações "são tão mudas que aceitam qualquer interpretação", é nessa característica que enraíza a diversidade de narrativas acerca desses espaços, nessa relação que se instaura o diálogo entre o imaginário (do sujeito) e os motivos percebidos (pelo sujeito). O confronto destes formula $o$ entendimento da situação, transformando o imaginário e a experiência vivida.

Dificilmente atingiremos o mais genuíno sentido dessas representações para os homens que a produziram, porém, para os arqueólogos, estes vestígios ainda são peças fundamentais do conjunto material restante da ocupação humana nessa região. Para o turista visitante é suporte para sua percepção e imaginação.

É interessante observar como essa paisagem, que revela traços da nossa ancestralidade, oferece a possibilidade, quando experimentada, do sujeito se referenciar no tempo e no espaço, criando possibilidades de transformações internas no sujeito. Estar presente e atuante no mundo é estar referenciado espacialmente, perceber que o espaço vivido no presente guarda marcas do passado e se configura como palco para ação futura, é estar referenciado temporalmente na história, essa percepção nos ajuda a seguir em frente, aprender com o velho e projetar o novo.

Nesses caminhos, somos renovados a cada dia, essas experiências podem ser materializadas nos gestos e nas palavras e de certa forma se projetarão nas próximas experiências desse indivíduo. As experiências carregam o imaginário, este, por sua vez, influencia nas experiências. 
As experiências acontecem a todo instante e, são mais ou menos marcantes dependendo do envolvimento do sujeito nas variadas experiências. O turismo possui dois fatores que influenciam para que as experiências nesse âmbito estabeleçam um maior envolvimento do indivíduo com o objeto experimentado. $O$ tempo no espaço e o estranhamento. Fazer turismo demanda tempo e, normalmente, se faz em espaços não cotidianos.

O estranhamento é uma característica interessante para pensar em turismo. É verdade sim que fazer turismo muitas vezes, eu diria em sua grande maioria, acontece em espaços que temos pouca familiaridade, distantes da nossa realidade. Assim, o estranhamento se instaura pelas diferenças experimentadas, no entanto, nossa percepção ainda é trabalhada pelo imaginário.

Mas não seria possível fazer turismo em um espaço cotidiano? Eu diria que sim, e o estranhamento ou o deparar-se, é peça chave nisso. A cada dia e ano após ano mergulhamos em novos imaginários, novos modos de saber e ver o mundo. Progressivamente percebemos novos espaços e objetos, antes excluídos da nossa consciência. Deparamo-nos com o estranho que sempre esteve ali.

O imaginário funciona como filtro das percepções conscientes, ou seja, o objeto que é percebido e experimentado se tornará significativo para o sujeito quando este intencionalmente o perceberá. Entretanto, os fatores co-percebidos (o sol quente, o terreno íngreme, a paisagem circundante) fazem parte dessa experiência e com certeza são preponderantes na vivência desse lugar.

O sítio Bisnau se apresenta ao visitante. Como percebê-lo? Devemos considerar que a interação do sujeito, aqui considerado turista, com o meio ambiente circundante ao lajedo, também acontece, uma vez que o individuo vive todo esse ambiente, em baixo do sol quente ou ao se refrescar na cachoeira, a subjetividade permeará a experiência, e todo o conjunto físico vivido se transforma no espaço vivido e vivenciado. Para Santos (1979), como o espaço é organizado socialmente, espaço e natureza são sinônimos, desde que se considere a natureza como uma instância transformada. A percepção do espaço do sítio arqueológico bisnau não se limita ao contato com o conjunto de petroglifos, mas a vivência de todo o contexto 
circunvizinho, portanto objetos que são co-percebidos também fazem parte do campo da percepção desse espaço. (MARTINS e FARINHA, 1984).

Para os arqueólogos, este espaço foi construído a milhares de anos, chegando até nós, no presente, como testemunho da história, uma história a ser preservada e perpetuada às novas gerações. O termo preservação aqui colocado não pode significar tornar estático, uni-verossímil, mas enquanto parte integrante da cultura deve como essa seguir os meandros da dinâmica cultural de uma sociedade.

Hoje, como no passado, tal ambiente faz parte da espacialidade que nos é possível vivenciar, dessa forma, continua a ser construída (o) e reconstruída (o), determinada pela subjetividade do individuo coletivo.

O turismo neste espaço diverge de outros espaços como praias e resorts, por exemplo, pela possibilidade de "viagem temporal" possibilitada pelos imaginários e as memórias do indivíduo. Outros espaços que podem possibilitar essa viagem são os museus e/ou centros históricos, pois, assim como o sítio arqueológico Bisnau, guardam em si a materialidade que nos possibilita traçar uma referência temporal e espacial, desencadeando um viagem mental à tempos pretéritos. Cabe ressaltar que nossa bagagem, nosso conhecimento prévio e nossas experiências passadas, guardadas no nosso imaginário, irão referenciar a materialidade percebida. . .

\subsection{Turismo}

O turismo no sítio arqueológico Bisnau em Formosa - Goiás será o objeto dessa pesquisa, que terá em alguns aspectos mais sensíveis e subjetivos dessa experiência, o meio elucidativo do fenômeno.

O desenvolvimento teórico do turismo se confunde com a própria evolução histórica do conhecimento cientifico. As primeiras pesquisas estabelecidas nesse âmbito se caracterizam por não serem totalizantes, privilegiando principalmente o viés econômico dessa atividade. Haja vista os estudos em turismo nos últimos tempos passarem a se dedicar a uma visão mais crítica, holística e complexa desse fenômeno, várias pesquisas ainda são pautadas em análises uni-disciplinares 
privilegiando as estáticas econômicas, os fluxo de pessoas e moedas, enfim, focados numa supervalorização das divisas geradas pelo setor.

A partir do avanço desse fenômeno, que salta aos olhos pelo forte apelo econômico destacam-se então, nesse âmbito, as pesquisas fundamentadas nas disciplinas de estatística e economia, privilegiando assim apenas uma faceta do fenômeno, sendo considerado por estes pesquisadores, uma "indústria sem chaminés" (MOESCH 2002).

Este tipo de análise parte do paradigma positivista que parece longe de ser quebrado no âmbito geral das universidades. Esse modelo deve ser superado, no entanto, não deve ser rechaçado, mas entendido que este tipo de análise alcança uma parte do fenômeno e que então é necessário se valer de outros métodos e teorias para pensar turismo. Propor a criação e utilização de apenas um método é inviável para a análise completa do fenômeno (PANOSSO NETTO e NECHAR, 2014).

O turismo, como declara Moesch, nasceu e se desenvolveu com o capitalismo, hoje, representa parcela significativa da economia de diversos países do mundo e movimenta pessoas e cifras vertiginosas, que começaram a tomar amplitude ainda na década de sessenta, estabelecendo "lugar garantido no mundo financeiro internacional" (MOESCH, 2002).

Sendo esse viés o mais destacado dentre as pesquisas realizadas nesse âmbito, observa-se o descontentamento por parte de alguns pensadores, que viam o turismo para além do quantificável. Começa a emergir aí discussões e reflexões de maior completude, percebendo o fenômeno turístico como um objeto da realidade que mereceria estudos mais aprofundados que realmente abrangessem a complexidade que o caracteriza.

Muitas pesquisas desenvolvidas na América Latina, em especial na Argentina, Brasil e México, foram influenciadas por outro paradigma: A teoria geral de sistemas. É considerado como criador e principal precursor do sistemismo, ou teoria geral de sistemas, o biólogo Ludwig Von Bertalanffy (1901-1972). Essa teoria tem por objetivo reduzir a complexidade do objeto ou coisa pensada dividindo o todo em 
partes menores mais facilmente alcanças e analisadas identificando suas singularidades e relações com o todo. No Brasil o principal autor a alicerçar seus pensamento acerca do turismo numa teoria de sistemas foi Mário Beni (1998), entretanto o primeiro autor a transportar e aplicar o pensamento sistêmico ao turismo foi Cuervo (1967)

Para Cuervo (1987):

O turismo seria um grande sistema, composto de outros conjuntos menores: meios de comunicação, estabelecimentos de hospedagem, agências de viagens, guias de turismo, estabelecimentos que oferecem alimentos e bebidas, estabelecimentos que oferecem bens de consumo aos viajantes, fabricantes de produtos típicos vendidos aos turistas, e os centros de diversão. Todos os sistemas devem ter um modelo que facilite sua compreensão (apud PANOSSO NETTO e NECHAR, 2014).

Ainda existem diversos autores mergulhados nesse paradigma e que, portanto, tratam de sistemas de turismo, destacam-se autores tais como o de Sessa (1985), Molina (1991) e Boullón (2002).

Há também outro paradigma em voga nos estudos em turismo atualmente e que pretende destacar que esse fenômeno só existe e é impulsionado pelos fatores econômicos de produção. Autores dessa linha consideram também que o "turismo nasceu a partir do surgimento do capitalismo e que são as leis econômicas que coordenam como, quando e para onde os turistas devem viajar" (PANOSSO NETTO e NECHAR, 2014 p.131).

No entanto, apesar de olhar o turismo pelo seu aspecto econômico, a ênfase dada ultrapassa as análises estatísticas e o analisam também acerca de como esse turismo, propiciado pelo capital, pode acarretar diversas problemáticas sociais e culturais.

Essa abordagem tem suas bases fundadas em solo marxista pregando que o turismo seria uma forma de imperialismo e colonialismo (Krippendorf, 1984; Nash, 1977 apud PANOSSO NETTO e NECHAR, 2014). 
Os que vivem nos países mais ricos têm mais propensão às viagens do que os que vivem nos países pobres. Quando ocorrem essas viagens, então pode ocorrer uma situação de opressão. Quem viaja tem dinheiro e tempo livre, demonstrando estar em uma posição de privilégio diante de quem recebe o turista (PANOSSO NETTO e NECHAR, 2014).

Uma tendência surgida já no século $X X$ e que tem ganhado espaço nos estudos de turismo é a fenomenologia.

Um dos temas estudados por ela é a experiência humana. A partir da concepção de que a experiência também é um dos elementos principais do turismo, a fenomenologia passou a ser aplicada nos estudos sobre o turismo. A descrição fenomenológica baseia-se na observação e na percepção do turismo como um fenômeno altamente dinâmico, desenvolvido no tempo e no espaço por um indivíduo ou um grupo. Fenômeno turístico, portanto, seria algo que se mostra a si mesmo, tal como é, do modo que é (Panosso Netto, 2011).

O turismo pressupõe a existência de contigentes de pessoas(turistas) que se deslocam para fora do seu lugar habitual de residência durante um período de tempo, com sua carga de expectativas provenientes das mais diversas fontes (propaganda, amigos etc) e pelos mais diversos motivos (BARRETTO, 2007)

Fica claro aqui, que pensar turismo deve estar vinculado a pensá-lo em seu aspecto sócio-cultural, inerente a humanidade e suas atividades no mundo; a prática dos espaços através do tempo e, por seu fator psicológico que é levantado nos aspectos das motivações e pelo imaginário criado através das mais diversas narrativas percebidas.

O turismo é um "fenômeno social que consiste em uma viagem de ida e volta, voluntária, com a tônica na interrupção do cotidiano, na qual, o turista se coloca em uma viagem para buscar sensações ímpares e experiências marcantes, a fim de atingir a expectativa gerada antes da viagem (PANOSSO NETTO, 2010)". E, portanto um feito social, humano, econômico e cultural irreversível (ICOMOS, 1976). 
O turismo implica deslocamento, que é gerado por alguma motivação de vivenciar algo alheio à seu cotidiano físico e/ou simbólico. A motivação nasce ainda de modo conceitual (ideal), antes mesmo do deslocamento e exerce papel chave no plano das expectativas.

Para que se avance nas construções conceituais no campo de conhecimento do fenômeno turístico, entender a trama que se estabelece e se configura perpassa pelo entendimento que o turismo vincula-se a sociologia por seus aspectos sociais, à geografia por seu conteúdo espacial, à psicologia pelo comportamento individual, social e de grupo do turista e pela investigação motivacional que lhe é conexa (MOESCH, 2002). Tais filiações devem estar condensadas, integradas umas as outras de modo interdisciplinar, que como destaca Moesch, é postura fundamental para análise do turismo como fenômeno social, cultural, comunicacional, econômico e subjetivo (MOESCH, 2002). Como afirma CASTROGIOVANI (2009):

\footnotetext{
O contexto do Turismo é, essencialmente, geográfico, pluriculturalista, polissêmico, plural. Constitui-se num fenômeno sociocultural de valor simbólico aos Sujeitos que o praticam e aos Sujeitos que vivem nos lugares onde ele é praticado. Há uma publicização, incentivada pelo marcado neoliberal da comunicação, quanto às IMAGENS que devem ser consumidas pelo Sujeito Turístico (CASTROGIOVANI, 2009).
}

Entendendo a complexidade em que o fenômeno "turismo" se apresenta, pesquisar os seus processos parte do reconhecimento que este é uma amálgama composta pelas esferas social, psicológica e espacial, e que o fenômeno acontece no ponto de convergência dessas esferas. Essa pesquisa é realizada com esse olhar, em que parte do processo do turismo no sítio arqueológico Bisnau é entendido como uma experiência, no tempo e no espaço influenciada pelo imaginário, experiência essa que transforma os sujeitos e os lugares visitados.

O turismo, na atualidade, bastante enviesado para os aspectos econômicos desse fenômeno procura divulgar paisagens através de imagens manipuladas pelas estratégias de marketing e veiculadas pela comunicação e pela mídia e que chegam até nós "turistas consumidores" como produto a ser experimentado. Segundo Suzana Gastal (2005) os "produtos pós-modernos não vendem apenas a si mesmos, 
precisam agregar imaginários porque os novos clientes necessitam dos dois: do objeto e do imaginário, sendo que o imaginário [...] pode ter valor de mercado muito superior ao objeto em si”.

Uma paisagem bucólica ou que incita a aventura, um destino badalado ou uma praia deserta, aí se apresenta muito mais que apenas os aspectos físicos de um destino, se procura passar um ideal e, assim, atingir o imaginário de um individuo ou grupo. O Imaginário é laço que une subjetivamente uma sociedade. Seria um "sentimento coletivo" (GASTAL, 2005) partilhado por um grupo, uma visão de mundo.

Alguns trabalhos abordam as relações entre imagem, àquelas produzidas pelas lideranças de marketing turístico (GASTAL, 2005) ou pelo próprio individuo que a cria a partir de um relato, história ou qualquer narrativa (CORDEIRO, 2008) e o imaginário. É interessante analisar como o imaginário individual/coletivo do sujeito social e histórico formata as imagens percebidas, a qual por sua vez, vai configurar um novo imaginário.

Suzana Gastal (2005) analisa o turismo na pós-modernidade e identifica que esta sociedade privilegia o sentido da visão e, que o marketing turístico se valendo disso, produz imagens que procuram atingir um imaginário ideal e que faça com que o turista consumidor sinta a necessidade de experimentar determinado destino.

A questão da comunicação, da mídia e da propaganda, principalmente com o avanço das tecnologias nos últimos tempos, deve ser levada em conta nas pesquisas no âmbito do turismo. Nessa pesquisa, não aprofundaremos esse viés, entretanto, tomaremos emprestado o produto desses componentes: a imagem que é produzida de um atrativo, e muitas vezes já vem carregada de sentidos e significados que criam ou atingem imaginários representando paisagens turísticas.

Para Gastal (2013) a paisagem turística é dependente do olhar do espectador, que seleciona e hierarquiza o que vê. Essa dependência parte do imaginário que determinado indivíduo/coletivo possui. 
Portanto essa pesquisa abordará o fenômeno turístico no sítio arqueológico Bisnau a partir da experiência do individuo naquele espaço e se apresenta como "um estudo das razoes essenciais e do significado transcendente do turismo para os seres humanos em função do seu próprio mundo interior e não apenas da perspectiva da sociedade de consumo" (BARRETO, 2000 apud PANOSSO, 2005).

\subsection{Pensar Turismo Arqueológico Pensando em Turismo}

A segmentação do turismo, seja de cunho acadêmico ou comercial, pode ser prenúncio à deficiência de uma análise ou operação não totalizante desse fenômeno. Por outro lado pode favorecer metodologicamente uma pesquisa ou uma estratégia econômica desde que seja entendido que a parte analisada compreende o todo desse fenômeno social, histórico e econômico.

Analisando o mercado turístico e suas viabilidades de gerar fluxo monetário e divisas, entretanto com "função primordial da redução da pobreza e a inclusão social" o Ministério do Turismo identifica que o comportamento do sujeito turista vem mudando nos últimos tempos e que começam a surgir "novas motivações de viagens e expectativas que precisam ser atendidas [...] a cada dia os turistas exigem, cada vez mais, roteiros turísticos que se adaptem às suas necessidades, sua situação pessoal, seus desejos e preferências" (MINISTÉRIO DO TURISMO, 2010). Destaca-se a importância, entre outros, dos fatores psicológicos envolvidos em todos os momentos do fazer turismo, "desejos e preferências" são fatores relevantes na tomada de decisão de pra onde ir. Neles se encerra o porquê ir.

O turismo arqueológico é um subsegmento dentro do turismo cultural que por sua vez "compreende as atividades turísticas relacionadas à vivência do conjunto de elementos significativos do patrimônio histórico e cultural e dos eventos culturais" (BRASIL. M.Tur, 2006). Este tipo de turismo favorece uma experiência do sujeito turista com algum patrimônio histórico e cultural, o que significa vivenciar, sentir, captar a essência do lugar visitado e do seu povo. 
Para Margarita Barretto (2007):

Turismo cultural é todo turismo no qual o principal atrativo não é a natureza, mas um aspecto da cultura humana, que pode ser a história, o cotidiano, o artesanato ou qualquer dos aspectos abrangidos pelo conceito de cultura (BARRETTO, 2007).

A visão de Barretto (2007) me parece parcialmente equivocada ao excluir os aspectos naturais numa viagem de turismo cultural. É sabido que variados espaços naturais e geográficos integram uma história e/ou um imaginário de um povo ou cultural. Isso é bastante trabalhado pelos mitos de origem, as toponímias, o valor de um rio ou uma porção de terra para a sua gente, tornando-os praticamente sagrados.

Turismo Cultural caracteriza-se, conforme Moletta (2000), "pela motivação do turista em conhecer regiões onde o seu alicerce está baseado na história de um determinado povo, nas suas tradições e nas suas manifestações culturais, históricas e religiosas". Este tipo de turismo tem por objetivo, entre outros fins, o conhecimento de monumentos e sítios histórico-artísticos (ICOMOS, 1976).

Para entendermos turismo cultural e não incorrermos numa visão diminuta do próprio fenômeno turístico que ai se estabelece, é preciso revelar que este tipo de turismo não diverge de outros tipos de turismo pelo objeto físico da visita - o sítio arqueológico, o centro urbano, os museus - mas pela motivação gerada num momento anterior. Uma praia deserta ou badalada pode ter sido o cenário de um importante evento histórico, cabem aos turistas realizarem uma, outra, ou as duas experiências nesse mesmo espaço. Copacabana no Rio de Janeiro, por exemplo, nos dá a possibilidade de realizar um turismo de massa ou de evento (virada do ano, entre outros), no entanto possibilita sim um turismo cultural, na visita ao Museu Histórico do Exército e ao Forte de Copacabana.

De acordo com a Organização Mundial do Turismo, o turismo cultural inclui o conhecimento da cultura e dos ambientes culturais, compreendendo a paisagem do lugar. Nesses atributos encaixam-se sítios arqueológicos monumentos históricos e outras manifestações artísticas do local, bem 
como os valores e formas de vida, o patrimônio [...] as atividades cotidianas, as tradições e as formas de recreação da população local. (WTO, 2004: 23)

Entendo, portanto, que toda forma de turismo, é de certa modo, uma viagem cultural. Provamos da culinária local, percebemos os sotaques e alguns hábitos, ou seja, trocamos com os espaços vividos e com a comunidade do lugar.

Destarte, o turismo ao sítio arqueológico Bisnau não se faz apenas no lajedo rupestre, tampouco uma experiência desse tipo vai restringir as percepções, interpretações e posicionamentos do turista apenas em relação ao espaço restrito das inscrições milenares. As descobertas, os olhares atentos, a vivencia dos vários espaços em que passa um turista começa desde a saída de sua casa e do seu cotidiano, passando pelo deslocamento do lugar de partida e o espaço imaginado bem como na sua experiência durante a visitação.

O turismo cultural pode possibilitar também um movimento contrário interessante. Este tipo de turismo normalmente ocorre em lugares de identidade forte, onde suas historias são consideradas por seu povo. No entanto, é possível que aconteça a valorização de um lugar pela sua comunidade a partir do valor que é dado pelos turistas que vistam esses lugares.

Para Barretto (2000)

O turismo com base no legado cultural permite que se mantenha, em um lugar específico, um determinado período do tempo, que deu origem a essa comunidade. Permite que a comunidade, de alguma forma, engaje-se no processo de recuperação da memória coletiva, de reconstrução da história, de verificação das fontes. Permite, até mesmo, que muitos membros da comunidade adquiram, pela primeira vez, consciência de que sua cidade representou em determinado cenário e em determinada época (Barreto 2000, p.49). 
Assim, o turismo arqueológico pode ser considerado parte integrante do turismo cultural, mas antes disso é uma forma de fazer turismo e as premissas básicas fatores sócio-culturais, psicológicos e espaciais - se revelam como nos demais segmentos turísticos.

\subsubsection{Turismo Arqueológico}

Já levantados alguns conceitos referentes a arqueologia e o turismo trataremos de unir esses dois campos de atividade e conhecimento e definir o escopo dessa dissertação. A experiência turística em um sítio arqueológico. $O$ turismo arqueológico ou arqueoturismo:

\footnotetext{
consiste no processo decorrente do deslocamento e da permanência de visitantes em locais denominados sítios arqueológicos, onde são encontrados os vestígios remanescentes de antigas sociedades, sejam elas pré-históricas e/ou históricas, passiveis de visitação terrestre ou aquática (MANZATO, 2005).
}

Haja vista o turismo pressupor deslocamento voluntário a um destino escolhido, o turismo arqueológico nada mais é que a visitação turística a esses espaços, que, durante os anos sofreu ação humana, foi transformado e guarda as marcas dessa dinâmica.

Quando citado que os espaços arqueológicos são resultados da ação humana, Child (1987) salienta que nem toda a conduta humana se conserva registrada materialmente. A palavra que se fala, o rito de passagem nas águas da cachoeira, a essas ações jamais se terá acesso, porém, temos acesso ao mesmo lócus de reminiscências que homens e mulheres viveram a milhares de anos, dando-nos a possibilidade de experimentá-lo à nossa forma.

A experiência turística é momento de liberdade de escolha e relativamente de conduta. A visitação ao sítio arqueológico Bisnau deve ser entendida como a visitação a um complexo espacial total, para além do lajedo e, que permita a percepção individual. 
Não incito que se deva rechaçar todo espaço aparentemente não transformado pela impossibilidade de acesso aos gestos do passado, mas perceber a alma do lugar que se transforma com a experiência no presente.

Eduardo Yázigi (2001), ao tecer reflexões acerca da alma do lugar declara que:

\begin{abstract}
Alma são materialidades, práticas e representações com uma aura que se contrapõe ao que chamaríamos "desalmado". Não creio que possa ser entendida por processos lógicos. Há alma quando há paixão das gentes pelo lugar. A alma orbita além da ciência, e tem de ser entendida num plano mais elevado que o formato acadêmico ( $p: 24)$
\end{abstract}

A partir da disposição das formas nos lugares, produzida pela comunidade e por toda materialidade dos povos que tiveram determinado espaço como lugar para si, o sujeito que visita the confere também um alma, que surge do imaginário que esse individuo tem desse espaço. A alma do lugar num espaço turistico, portanto, seria os sentimentos de pertença que a comunidade imprime e exprime em determinado lugar mas, também as relações desenvolvidas entre o turista e esses espaço, dotando-os de especificidades e valor. "Ainda que dois lugares possam ter os mesmos ingredientes, a disposição de suas formas pela comunidade produz algo necessariamente diferente. É quando a ordem dos fatores altera o produto. Homem apaixonado pelo meio cria a alma do lugar" (YÁZIGI, 2001: 25)

Refletindo com esse autor, que navega pelo conceito de lugar buscando amplia-lo, entende-se que cultura e personalidade, identidade, geografia física, "espaço vivido" "sentimento de pertença", paisagem, arquitetura, simbólico, memória e modos de vida são atributos que caracterizam a alma do lugar (YÁZIGI, 2001)

As pesquisas desenvolvidas por vários autores que tem objeto de pesquisa o turismo arqueológico, e que tratam dessa temática, estão, em sua maioria, preocupadas com vieses mais economicistas e mercadológicos ou enfocam o papel importante que o turismo nesses espaços pode desempenhar na preservação desse patrimônio e para difusão do conhecimento histórico de uma região. 
A proposta aqui é tentar pensar como os indivíduos são movidos pelos imaginários individuais/coletivos, como estes imaginários influenciam nas diversas experiências do sujeito e de que forma esse individuo, que vive o mundo, se relaciona com os espaços e lugares.

O sítio arqueológico Bisnau, principalmente as inscrições do lajedo dão margem para extensões diversas da imaginação, gerando discursos que influem na motivação de um ou vários sujeitos. Uns dizem que são mapas astronômicos, outros acreditam na influencia de extraterrestres na confecção das inscrições, essas diversas narrativas instauram imaginários que projetado na linguagem delineiam uma representação da realidade.

Importante ressaltar as três esferas envolvidas no fazer turístico e que também são características do turismo no sítio arqueológico Bisnau e que dão tamanha complexidade a esse fenômeno, mas, ao mesmo tempo norteiam uma visão integradora e plural do fazer e do saber turístico, à saber: esferas física, psicológica e social.

A necessidade de deslocamento exige que o indivíduo percorra o espaço físico, se jogue no mundo, isso parte de desejos e motivações geradas quando imaginamos um destino. Por fim, vivemos o espaço, nos relacionamos com ele e com os outros diversos atores que certamente estarão envolvidos nesse percurso.

Turismo Arqueológico é então:

deslocamento voluntário e temporário de indivíduos, motivados pelo interesse ou desejo de conhecimento de aspectos pertinentes a culturas passadas, a locais onde se encontram vestígios materiais representativos de processo evolutivo do homem no planeta, deixados por sociedades pretéritas" (Grifo nosso WIDMER, 2009)

Conforme declara Panosso (2005), "é muito provável que toda viagem dependa muito mais do porque ir e do como ir do que o onde ir". Pretendemos analisar daqui para frente como o imaginário permeia as experiências dos indivíduos no mundo os 
caminhos, gera motivação, desejos de visitar e como se delineia a visitação ao sítio arqueológico Bisnau.

Nossas viagens turísticas partem do desejo de viajar, pela motivação de conhecer novos lugares e pessoas. Construímos imaginários acerca dos possíveis destinos e o fazemos a partir das narrativas que recebemos a todo tempo e nos incitam em maior ou menor grau. As propagandas ou os relatos de pessoas conhecidas, que nos contam sobre suas experiências e, de certa forma, nos banham com a alma do lugar, nos atingem e somos tomados pela vontade de experimentar também os destinos relatados. Escolhemos um lugar ou outro no intuito de suprir nossos anseios e vontades criadas antes do deslocamento físico ao destino imaginado.

No excerto de Panosso (2005) acima, minha posição não seria hierarquizante em relação às perguntas - Porque ir? Como ir? Aonde ir? - que o turista se faz antes de realizar sua sonhada viagem de férias. A meu ver, as perguntas acima quase que acontecem de maneira simultânea, mas as decisões tomadas ocorrem em tempos diferentes, ao ponto que a frustração que pode acometer o aonde ir, pelo como ir, pode alterar drasticamente sua viagem. Se o como ir não seja um problema, tentaremos unir nossa motivação (descanso, aventura...), ou seja, o porque ir, e o desejo de experimentar um espaço que supra nossa motivação, aonde ir.

É salutar que o aonde ir, muitas vezes é possível de ser alterado, mas sempre buscando saciar uma mesma motivação. Se nossa viagem é balizada pela necessidade de descanso e contemplação de pelas paisagens, temos um grande leque de oportunidades. Praias, montanhas, campos entre outros.

Coloco-me como exemplo. Criei uma expectativa grande no final do ultimo ano de poder visitar o Caribe, que, aliás, é carregado de imaginários, mitos e histórias. As belas imagens e paisagens que chegam até nós são de esplêndidas águas, deliciosas praias de areia branca e sombras de coqueirais. Minha motivação era então experimentar esse tipo de ambiente e afagar meu imaginário sobre a região caribenha. Entretanto, com a arrancada do dólar, a viagem, no momento se tornou inviável. Mas ainda assim parte dos meus desejos poderão ser sanados, o litoral 
brasileiro está recheado de belas praias que certamente alcançaram algumas das minhas expectativas. O Caribe fica para a próxima.

Depreende-se que minha motivação pode se manter, no entanto caso o como ir impeça de alguma forma o deslocamento o aonde ir pode ser alterado.

Penso então, que as perguntas estão em esferas diferentes de decisões. O como ir se encerra numa esfera espaço-territorial e de infra-estrutura, podemos querer visitar a Coréia do Norte mas a distância e a rigidez da ditadura que, certamente endurecerão a entrada, a permanência, bem como o controle da liberdade de escolhas e decisões podem nos fazer pensar duas vezes. Podemos desejar conhecer o espaço. Podemos! Mas nesse instante, nem todos de nós.

O aonde ir, apesar de poder ser alterado em alguns casos, na mesma medida que 0 como ir, pode interromper uma motivação. Minha motivação em visitar o Caribe não será suprida em qualquer outro espaço similar. Dessa forma, ainda que o porquê ir, seja 0 desencadeador de todo o processo de fazer turismo os demais questionamentos são fundamentais para que o turismo aconteça. 


\section{CAMINHOS E POUSOS: A EXPERIÊNCIA TURÍSTICA REPOUSA NO IMAGINÁRIO}

Em toda nossa viagem, em toda nossa caminhada, nas paradas, nas partidas percebemos o mundo, experimentamos essa vivência. A experiência do sujeito que atua no mundo é inerente também aos deslocamentos turísticos e é nessa atuação que o sujeito se situa no tempo e no espaço, refletindo e se reposicionando a todo instante, a cada estranhamento a cada descoberta. Nossa experiência conceitual ou nos espaços físicos são balizadas pelo imaginário que influencia na percepção do mundo e também nos modos de ver e interpretar esse mundo.

\subsection{Imaginário}

A motivação, peça chave para os deslocamentos turísticos, parte do desejo e dos anseios de satisfazer vontades criadas muitas vezes a partir do conhecimento ainda conceitual de um objeto ou destino (turístico). Quando somos atingidos por belas imagens e discursos produzidos pelas lideranças de propaganda ou quando escutamos as narrativas de familiares e amigos sobre determinado atrativo, começamos a delinear mentalmente o espaço que caso haja algum vinculo será visitado. Confrontando as imagens e discursos recebidos com as imagens e experiências passadas (contidas no imaginário) instaura-se uma representação da realidade do objeto ou destino vivido.

O sítio arqueológico Bisnau enquanto espaço de experiência turística revela em sua exterioridade imagens ou códigos de um passado que irrompe e se apresenta no presente, sendo então, percebido por homens, hoje, a sua forma. A formulação do real (construção dessa realidade) se inicia a partir de alguma experiência, que parte do contato de um sujeito com um objeto, ou do sujeito com outro sujeito, essa experiência pode ocorrer de forma material ou imaterial. 
Experiências são os modos pelos quais as pessoas conhecem e reconstroem uma realidade. Isto pode ocorrer de forma direta e íntima ou indireta e conceitual (TUAN, 1977). Entende-se aqui, como a construção do real sobre um objeto/espaço pode se estruturar ainda na experiência indireta a partir do nosso imaginário.

No turismo, para que haja deslocamento tem que haver motivação, a motivação para a viagem partirá, em grande parte, do imaginário sobre o espaço a ser visitado, vivido. Essa motivação se inicia na nossa consciência de modo subjetivo e é banhada pelo nosso imaginário.

O transladar de um turista em sua viagem é até certo ponto balizada pela construção do espaço a ser visitado ainda de forma conceitual, ou seja, de maneira ideial, no campo da imaginação. Dessa forma a construção da realidade é iniciada antes mesmo da visita, a partir do momento que se estabelece um imaginário sobre esse espaço. Como afirma Juremir Machado:

\begin{abstract}
O imaginário é um reservatório-motor. Como reservatório agrega imagens, sentimentos, lembranças, experiências, visões do real que realizam o imaginado, leituras de vida e, através de um mecanismo individual/grupal, sedimenta um modo de ver, de ser, de agir, de sentir e aspirar ao estar no mundo, o imaginário emana do real, estrutura-se como ideal e retorna ao real como elemento propulsor.

Como motor, o imaginário seria o sonho que realiza a realidade, uma força que impulsiona indivíduos ou grupos. Funciona como catalisador, estimulador e estruturador dos limites das práticas. [...] $O$ homem age (concretiza) porque está mergulhado em correntes imaginárias que 0 empurram contra ou a favor dos ventos (SILVA, J.M apud GASTAL, 2005).
\end{abstract}

Juremir Machado ao utilizar o termo reservatório - motor para conceituar o imaginário, deixa claro o movimento que se realiza quando este toma seu viés motor, é ação, essa ação se perfaz ainda de modo subjetivo, quando tomamos conhecimento sobre determinado objeto do mundo, a partir de narrativas, imagens, discursos entre outros, e iniciamos uma construção imaginária desse objeto, assim ainda em nossa consciência o real começa a tomar forma e principalmente conteúdo. 
A construção imaginária condiciona a segunda ação, que no turismo é a própria visitação turística que implica em deslocamento voluntário, ou seja, o contato corpóreo íntimo motivado pelo imaginário pré-formatado e agora projetado na experiência. A experiência aqui, para além de somente condicionada, toma seu caráter transformador e relacional e a partir do mundo agora vivido, o sujeito recebe a aura que emana desse mundo, gerando reflexão, posicionamento, e nova transformação subjetiva, reconstruindo imaginários (reservatório). Conforme Tânia Swain, o imaginário formula o real e é trabalhado por ele, num constante movimento de circularidade (SWAIN, 1994).

O conceito de aura acima referido é trabalhado por Walter Benjamim (1985), que o faz em referencia a aura das obras de arte - fotografias, pinturas, entre outras nesse ponto tentarei convergir meu lócus de pesquisa (sítio arqueológico Bisnau) numa instância que o lajedo e suas imagens apresentam-se também como arte para os turistas que visitam o sítio, no sentido de possibilidade de transcendência, estranhamento e conhecimento.

A aura da obra de arte, conforme Benjamim (1985) sustenta dois elementos principais. A materialidade da obra e seu aspecto fundamentalmente ritualístico, de transcendência. Para Benjamim a aura seria como uma trama singular de espaço e tempo: a aparição única do longínquo por mais próximo que esteja. (Benjamin 1985: 101)

O sítio arqueológico Bisnau me parece apresentar essas características. Apresenta imagens que revelam um passado milenar. O próprio discurso acadêmico traz as pinturas e gravuras enquanto "arte" rupestre. Enquanto para os grupos pré-históricos que confeccionaram tais figuras as motivações poderiam ser tanto artísticas quanto arbitrárias, no turismo, parece tomar sua real configuração enquanto obra de arte, objeto de contemplação e transcendência. 
Segundo Araújo (2010):

Em suma, a aura da obra de arte possui, para Benjamin, dois elementos principais: autenticidade e unicidade. A primeira se relaciona a seu substrato físico. Constitui o invólucro que envolve a essência da obra e contém seus elementos temporais e espaciais. Esse invólucro é peculiar por ser único, indissociável da essência da obra de arte e por registrar as transformações físicas e a história das relações de propriedade da obra. A unicidade, por sua vez, tem fundamento teológico, ritualístico. Confere à obra de arte um caráter único, pois a associa a um valor de culto (ARAÚJO, 2010: 124-125)

Não obstante, o turismo no sítio arqueológico Bisnau teria, a meu ver, similaridade com processos rituais, ou seja, seguimento de alguns padrões. A chegada, o estranhamento e a tentativa de significação das gravuras - bem como a parada na pamonharia Bisnau - são atos subsequentes e recorrentes no momento da visitação. Para além disso o envolvimento com os desenhos, numa tentativa de identificá-los, revela aspectos teológicos, de transcendência imaginária. No entanto é necessário estar aberto à essência da obra e não contempla-la de forma passiva percebendo apenas como uma exposição superficial, amorfa e sem conteúdo.

Em A obra de Arte na Época de sua Reprodutibilidade, Benjamin faz uma distinção entre a sua função como objeto de culto e a função que mais tarde ela veio a ocupar: a de mera exposição. No primeiro caso, ela tem aquele caráter único, mágico, que "transporta" o espectador, ou que o auxilia a elevar-se ao transcendente. No segundo caso, ela se transforma em mercadoria e perde as suas características iniciais (COSTA, 2012: 2)

Maffesoli (2001) acredita que essa aura proposta por Benjamim, seria o próprio imaginário que, ainda que não se veja, é compartilhado por grupos e sociedades. "Não vemos a aura, mas podemos senti-la. O imaginário, para mim, é essa aura, é da ordem da aura: uma atmosfera. Algo que envolve e ultrapassa a obra" (MAFFESOLI, 2001: 75). 
Maffesoli (2001) expressando concordância então com os pensamentos tecidos por Walter Benjamim declara que, o imaginário é essa aura, essa atmosfera que envolve, ultrapassa os objetos e nos atravessa, é uma força social de ordem espiritual, uma construção mental (MAFESOLI, 2007), é o próprio imaginário que delineia a realidade a partir de nossa subjetividade.

Percebe-se o caminho de formulação da realidade consubstanciado pelo imaginário. O sujeito que experimenta, que vive, é envolvido pela aura que emana do mundo, sente a alma do lugar.

Destaca-se o movimento retroalimentar de condição e (re)construção do real no momento da experiência vivida que desempenha o imaginário. $O$ "objeto" atravessa aquele que experimenta e, o imaginário liga, dando contorno, acontece uma "incessante troca que existe ao nível do imaginário entre as pulsões subjetivas e assimiladoras e as intimações objetivas que emanam do meio cósmico e social" (DURAND, 1997 apud SILVA 2010)

O imaginário é campo de decisões mentais que se configuram de diferentes formas em variados períodos e sociedades. Assim estabelecido, objetos são experimentados de forma conceitual ou direta. $O$ imaginário circula através da história, das culturas e dos grupos sociais, como um fenômeno coletivo, social e histórico (LEGROS et al., 2005).

Aproximando aos pensamentos tecidos por Milton Santos os "códigos" apresentados no lajedo rupestre do sítio Bisnau - um dos objetos de experiência do sítio - são como "formas espaciais", que se apresentam no seu aspecto físico, ou exterior dos objetos.

Do ponto de vista arqueológico essas formas reveladas a nós no tempo presente, desempenharam determinada "função" para os povos que ali habitaram. Hoje, o imaginário compartilhado pelos grupos e sociedades pós-modernas é outro, e as mesmas formas - a cargo da nossa percepção - se transvestem, e adquirem a alma que cada um de nós emprega a elas, sempre permeado pela subjetividade individual compartilhada pelos grupos. 
De acordo com Santos (1978):

[...] a forma é o aspecto visível, exterior de um conjunto de objetos: as formas espaciais; função é a atividade desempenhada pelo objeto criado; a estrutura-social-natural é definida historicamente: nela, formas e funções são criadas e instituídas. As formas e as funções variam no tempo e assumem as características de cada grupo social.

A estrutura-social-natural a qual fala Santos (1978) é fundada num terreno compartilhado, determinado pelas relações intra-culturais de uma sociedade ou grupo, dentro de cada um desses grupos e sociedades e na amplitude total de suas culturas insere-se o imaginário. $\mathrm{O}$ imaginário, parcela da estrutura-social, assume as características desse grupo ou sociedade.

Para representar essa relação das formas/funções expressas na fisicalidade do lajedo do sítio arqueológico Bisnau e o imaginário construído e compartilhado por determinado grupo, faço uma analogia em Maffesoli (2001) que afirma que: não é a imagem que produz o imaginário, mas o contrário. A existência de um imaginário determina a existência de conjuntos de imagens. "A imagem não é o suporte, mas o resultado. Refiro-me a todo tipo de imagens: cinematográficas, pictóricas, esculturais, tecnológicas, entre outras" (MAFFESOLI, 2008, p. 76).

Para Durand (1997), imaginário seria o "conjunto de imagens e relações de imagens que constitui o capital pensado do homo sapiens". Fala-se aqui de imagens subjetivas, para além das imagens exteriores captadas pelo olhar.

O imaginário reserva imagens internalizadas que se projetam no momento da experiência turística. A imagem subjetiva ou interna faz referência não apenas ao sentido da visão, mas também a qualquer modalidade sensorial. Assim, "as imagens internas podem ser visuais, auditivas, gustativas, olfativas e táteis" (SODRÉ, 2006).

Temos ainda, pela observação básica de Juremir Machado da Silva (2006), que o imaginário deve sempre ser entendido como algo mais amplo que um conjunto de imagens. O imaginário não seria um mero álbum de fotografias mentais nem um museu da memória individual ou social. Tampouco se restringiria ao exercício 
artístico da imaginação sobre o mundo. "O imaginário é uma rede etérea e movediça de valores e sensações partilhadas concreta ou virtualmente" (SILVA, 2010).

Entendemos aqui como o imaginário atua na experiência turística ao sítio arqueológico Bisnau. Como o imaginário influencia na interpretação dos motivos rupestres. Entretanto, ainda se busca desvelar algumas questões. A experiência direta transformou o imaginado? O sujeito turista se transformou? Qual relação estabelecida entre os indivíduos e os espaços vivenciados?

Partiremos da análise das narrativas resultantes da experiência dos indivíduos em todo o processo turístico, bem como das versões da comunidade vizinha ao sítio e outros atores que significam este espaço para tentar responder essas perguntas.

Antes disso, vamos trabalhar o conceito de experiência e entender como através delas um sujeito se relaciona com o mundo e com os outros e como essas experiências são transformadoras, rearranjam os sujeitos que se relacionam e, os espaços que são suporte físico para essas experiências.

\subsection{Experiência}

A motivação para experiência turística em um sítio arqueológico parte do imaginário formatado sobre o local, por parte do turista, este compartilha determinados imaginários que compilam suas previsões do lugar a ser visitado gerando maior ou menor motivação. Assim, antes mesmo da visita acontecer, o turista imagina (concebe subjetivamente) o espaço que ainda será vivido. Graburn (2009) considera que as experiências dos turistas sobre os lugares variam, dependendo do conhecimento prévio, dos valores e das expectativas criadas sobre a visitação.

O momento da visitação, ou seja, quando o individuo se depara com o objeto imaginado, que ainda a certo ponto é estranho pela sua não cotidianidade e começa a percebê-lo através dos sentidos fisiológicos (visão, audição etc.), o imaginário é acionado, e aí se delineia a realidade da visita. No entanto, através dessa mesma experiência o imaginado antes da experiência pode ser reformulado. $O$ momento 
supracitado conforma o momento da experiência material ou direta, ou seja, do vinculo corpóreo com o objeto, e enquanto experiência é facticidade.

Em relação ao turismo, percebo dois tipos de experiência que acontecessem e que estão totalmente inter-relacionadas. A experiência indireta e direta. A primeira acontece no caso do turismo, quando temos o contato com destinos que nos despertam a vontade e a possibilidade de visitar e que chegam até nós através dos vários canais de comunicação: televisão, internet, relatos de amigos e parentes. A segunda seria a própria visitação ao local imaginado.

Experiência pode ser definida como "a totalidade de meios pelos quais nós chegamos à compreensão do mundo: nós conhecemos o mundo através da sensação (sentimento), percepção e concepção" (TUAN, 1979, 388 apud HOLZER). Experiência são os modos pelos quais as pessoas conhecem e reconstroem uma realidade (TUAN, 1977).

Em relação ao turismo Gastal e Moesch afirmam que:

[...] o turismo envolveria processos de estranhamento, ou seja, o turista, em seus deslocamentos, ao se defrontar com o novo e com o inesperado, vivenciaria processos de mobilização subjetiva que o levariam a parar e a re-olhar, a repensar, a reavaliar, a ressignificar não só a situação, o ambiente, as práticas vivenciadas naquele momento e naquele lugar, mas muitas das suas experiências passadas (2007).

Como citado pelas autoras a experiência - nesse estudo direcionado à experiência turística - funciona como agente de transformação que tem como meio, o embate entre a experiência esperada ou imaginada e a experiência vivida. As experiências então funcionam como motor de reflexões e redirecionamentos num confronto continuo do que eu sou e o que passo a ser, do que penso e de como passo a pensar.

É bom deixar claro que todo motor necessita de um combustível e o combustível para experimentar e refletir sobre o pouco cotidiano ou não são as subjetividades ou imaginários compartilhados por determinado grupo ou nação sobre determinada temática ou objeto. Em outro ponto de sua reflexão Juremir Machado Silva afirma 
que, como motor, o imáginário seria o sonho que realiza a realidade, uma força que impulsiona indivíduos ou grupos. O homem age (concretiza) porque está em correntes imaginárias que o empurram contra ou a favor dos ventos (SILVA apud GASTAL, 2005).

Acerca da experiência e do imaginário que a permeia, Netto e Gaeta (2010) apresentam excerto do conceito de experiência. Experiência é o defrontar-se com o mundo, o imaginário "representa”, "delineia" essa relação.

\begin{abstract}
Cada indivíduo possui uma carga de experiência vivida que o carrega. É o mundo em si, que nos é representado, e o modo como encaramos e vivemos o mundo é manifesto por nossas palavras e atitudes. $O$ relacionamento com a própria experiência envolve memória, reconhecimento e descrição, todos aprendidos por habilidades exercidas nas relações interpessoais, seja em grupo mais restrito, seja na sociedade (Oxford: Oxford University Press, 1996, p. 130 apud NETTO e GAETA org., 2010, p. 26).
\end{abstract}

Evidenciado a importância dos conceitos de experiência e imaginário para o entendimento do fazer turismo no sítio arqueológico Binau, partiremos agora para delinearmos o suporte espacial que dá a possibilidade de deslocamento, experiência física e intimidade afetiva nesse processo. O espaço. 


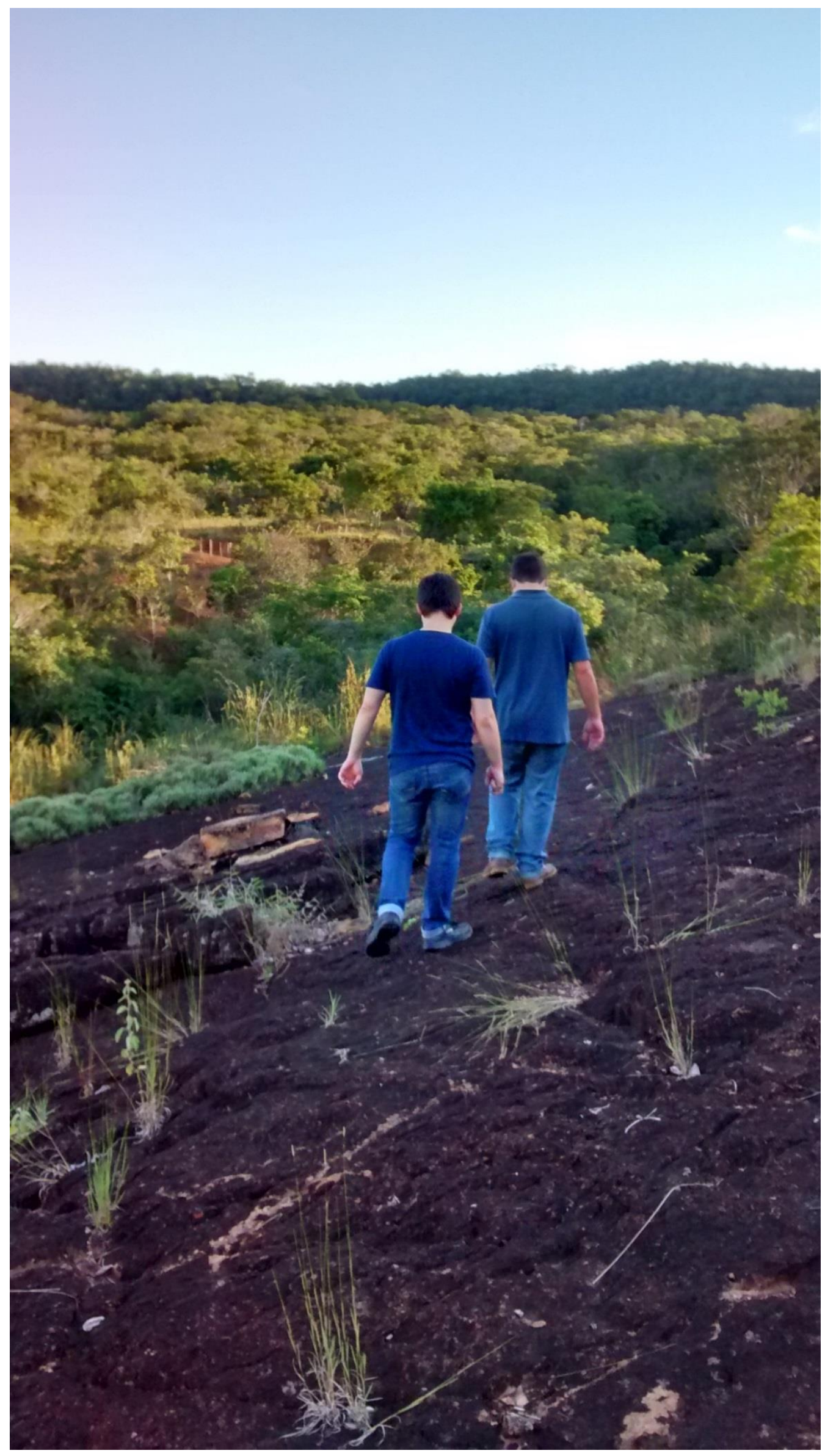





\section{ENTRE ESPAÇOS e ENTRE-LUGARES}

Os conceitos de espaço e lugar são amplamente trabalhados na disciplina de geografia e enveredam por caminhos mais ou menos objetivos dependendo da "lente" metodológica declarada pelo pesquisador. Grande parte dos trabalhos no âmbito dessa disciplina conduzem sua pesquisa num viés positivista, privilegiando os aspectos externos dos espaços, como o tamanho de um território, por exemplo.

Na década de sessenta surge a chamada Geografia Crítica, impulsionada pela discordância dos (de alguns) ideais positivistas e apoiada em solo marxista, vai começar a colocar o homem nos estudos geográficos, nessa linha, o espaço é construído pelo homem. A fonte marxista aqui também empresta o conceito de historicidade, o homem evolui, e transforma o espaço.

Quase concomitante, surge a geografia humanista que coloca de vez o homem nos estudos da geografia. Entende os espaços e lugares tão somente pela relação do homem no mundo, numa perspectiva da experiência, de mundo vivido, passando a privilegiar aspectos mais subjetivos dessa relação.

Os estudos geográficos irão corroborar aqui para o entendimento das relações do turista em um espaço arqueológico e como a partir da experiência do sujeito, esse espaço agora vivido e sentido se transforma em um lugar. Essas relações dos homens nos espaços revelaram a formatação de um espaço turístico delimitado em um espaço geográfico.

Não pretendo aqui iniciar um debate caloroso acerca dos conceitos de espaço e lugar, porém, enunciarei algumas perspectivas acerca do tema. Fundamentarei minha concepção nas propostas teóricas principalmente de Yi-Fu Tuan e Milton Santos, tão somente pelo desenrolar das reflexões que pretendo estabelecer, tendo nesses autores, maiores pontos de convergência intelectual que os demais. 
O espaço turístico é composto por espaços e lugares que darão suporte físico para o deslocamento e o estabelecimento temporário dos turistas nos destinos escolhidos. A saída do seu lugar habitual, o translado realizado entre aeroportos, hotéis, até a chegada ao lugar desejado, serão realizados espacialmente. Ainda nesse entremeio realizamos refeições, fazemos compras efetuamos diversas atividades auxiliares que farão parte de toda essa experiência. Experiência turística é antes de tudo a prática de espaço e lugares.

\subsection{ESPAÇO E LUGAR}

Estabelecer os conceitos de espaço e lugar é tarefa "cambaleante", à luz dos autores pesquisados, hora lugar é espaço, hora espaço é lugar. Portanto me parece adequado entender a essência do conceito de espaço e sua mutação em lugar, que superficialmente se traduz no fluxo de uma instância espacial não vivida e/ou experimentada em profundidade para aquela que será travada um contato intimo carregado de subjetividade. Os referenciais adotados me levam a estabelecer o conceito de espaço para expressar a primeira instancia acima referida e Lugar para a segunda.

Para Michel de Certeau (1998), a primeira instancia acima citada seria o "Lugar", onde ainda não se estabeleceu o contato necessário para que significados e relações sejam criadas. Dessa forma, para este autor, espaço seria então o lugar praticado, vivenciado. Milton Santos deixa clara a necessidade de se pensar o espaço como um espaço construído e organizado socialmente o que traz o homem a cena.

Avançando um pouco mais para entender esses conceitos, me aproximo dos pensamentos de Tuan que vê "o lugar" enquanto instancia de vivência. Para isso é necessário considerar a subjetividade das relações dos fatos vividos, como esse mundo percebido mobiliza memórias, sentimentos e imaginários que permeiam a realidade vivida. 
O turismo enquanto fenômeno realizado por sujeitos que se deslocam voluntariamente em busca de experimentar espaços pouco cotidianos e tomando as discussões acerca de experiências citadas no tópico anterior, depreende-se quão subjetiva é essa experiência. Tuan ao trabalhar num viés fenomenológico considera que esse espaço vivido, percebido, campo de trocas imaginárias e subjetivas tornase então um "lugar". Lugar é espaço vivido, com envolvimento e é pela experiência que se preenche esse espaço de sentido.

O lugar, portanto é um espaço praticado, experimentado, que percebido, desencadeia processos de estranhamento/reconhecimento, ou sentimentos e juízos de valor. Aqui se troca com o lugar, é muito mais que fisicalidade bruta é um transladar de sensações e imaginários. "O lugar é produto das relações humanas, entre homens e natureza, tecidos por relações sociais que se realizam no plano do vivido, o que garante a construção de uma rede de significados e sentidos e que são tecidos pela história" e pela cultura (CARLOS, 2002). Os espaços naturais são então transformados pelos homens, que também sofrem transformação nesse embate.

Milton Santos (1997) ainda identifica outra instância correlata ao espaço e se diferencia desse pela ausência de atividade humana na sua delimitação geográfica, entretanto, se comporta como palco para as ações futuras e carrega em si marcas e rastros que contam parte da história daquele espaço, A paisagem.

Santos (2002), para representar a diferenciação entre paisagem e espaço traz referencia análoga a um acidente como o de Fukushima, por exemplo. O desastre químico de grandes proporções que ocorreu no Japão. Essa situação define bem o conceito de paisagem para Milton Santos. As imagens que vemos hoje, pelos noticiários e todo tipo de mídia nos remete então a "paisagem" da usina de Fukushima. Restam escombros, restam estruturas, restam ainda memórias difíceis de apagar. No entanto se apresenta destituída de vida humana. Caso, num futuro se estabeleça novas relações humanas nessa paisagem, esta então será um espaço experimentado no presente dando suporte a ação humana no presente. 
A usina, tempos atrás, era totalmente ocupada, e expressava suas relações entre homem e meio, nos modos de produção, nos processos estabelecidos, enfim, tudo que formatava a ação humana naquele espaço. O sítio Bisnau também carrega marcas de uma ocupação pretérita, expressa evidências, carrega em si o rastro da história humana.

Para Santos (2006) a paisagem é a porção da configuração territorial que é possível de abarcar com a visão, no entanto, acredita que, numa perspectiva lógica, a paisagem é já o espaço humano em perspectiva.

Durante a guerra fria, os laboratórios do Pentágono chegaram a cogitar a produção de um engenho, a bomba de nêutrons, capaz de aniquilar a vida humana em uma dada área, mas preservando todas as construções. O Presidente Kennedy afinal renunciou a levar a cabo esse projeto. Senão, o que na véspera seria ainda o espaço, após a temida explosão seria apenas paisagem. Não temos melhor imagem para mostrar a diferença entre esses dois conceitos (Santos 2006: 68-69)

Paisagem são as formas. Espaço são as formas mais a vida que as anima, é uma construção social subjetiva. Paisagem é a materialidade dos espaços. A paisagem se dá como um conjunto de objetos reais-concretos, ou seja, apresenta-se materialmente constituída. Nesse sentido, a paisagem é transtemporal, juntando objetos passados e presentes uma construção transversal.

Como afirma Milton Santos o espaço não pode ser estudado como se os objetos materiais que formam a paisagem tivessem uma vida própria. Paisagens são sistemas de objetos ou formas. Espaço é o conjunto de sistemas de objetos mais o sistema de ações (SANTOS).

A paisagem é história congelada, mas participa da história viva. São as suas formas que realizam, no espaço, as funções sociais.

Quando a sociedade age sobre o espaço, ela não o faz sobre os objetos como realidade física, mas como realidade social, formas-conteúdo. Isto é, objetos sociais já valorizados aos quais ela (a sociedade) busca oferecer ou 
impor um novo valor. A ação se dá sobre objetos já agidos, isto é, portadores de ações concluídas mas ainda presentes. Esses objetos da ação são, desse modo, dotados de uma presença humana e por ela qualificados (SANTOS, 2006: 71).

É perceptível essa constatação no sítio arqueológico Bisnau. A materialidade do sítio, com seus desenhos gravados, é socialmente definido enquanto atrativo turístico e vem desempenhando essa função a algum tempo. Dessa forma o espaço vivido revela em sua paisagem (materialidade) marcas do tempo, registros da história encravados no lajedo. A paisagem existe, através de suas formas, criadas em momentos históricos diferentes, porém coexistem no momento atual (SANTOS, 2006)

Dias (2010) trata da possiblidade de experimentarmos uma paisagem a partir do olhar. Isto é ver de maneira profunda, detalhada, estar em situação de alerta. Perceber além da materialidade. Olhar é aprofundar-se no visto é enxergar o não visto no que sempre esteve ali. Ou seja, é dar conteúdo ao até então não percebido. A autora traz que o deslocamento do olhar revela nuances antes não vistas. Detalhar o olhar para perceber o novo o que sempre esteve ali mas nuca foi notado. A paisagem se revela num movimento acelerado de pontos de vista distintos, ela é passagem, um deslocamento do olhar (DIAS, 2010). É sempre o que está diante de nós, pronto pra ser percebido, vivido e reinventado. Para essa autora experimentar a paisagem:

[...] seria ativar um movimento do olhar onde ver e não ver se articulariam, onde os pontos de não-visão, de um certo estado de cegueira se transformariam em inviso, em uma visão interna. Não se trata de ver tudo, de ver em panorama, mas sim de se aproximar para habitar, de detalhar para se situar, para olhar no mesmo, no espaço de sempre, a diferença. KARINA DIAS (2007)

Dias (2007) traz o prefixo in também no seu sentido de inclusão, nesse sentido, invisão seria um modo de ver interior, próprio. "Aproximar-se para habitar" é dar 
sentido a paisagem, ou seja, valorar a materialidade do espaço, desvelar valores nas formas é viver o apresentado diante de nós.

\footnotetext{
Uma casa vazia ou um terreno baldio, um lago, uma floresta, uma montanha não participam do processo dialético senão porque lhes são atribuídos determinados valores, isto é, quando são transformados em espaço. O simples fato de existirem como formas, isto é, como paisagem, não basta. A forma já utilizada é coisa diferente, pois seu conteúdo é social. Ela se torna espaço, porque forma - conteúdo (SANTOS, 2006: 71).
}

A essas duas visões soma-se a contribuição do geógrafo Augustin Berque8 que nos lembra que a paisagem articula o lado objetivo do mundo, isto é, ela se reporta a objetos concretos os quais existem realmente ao redor de todos nós (pedras, montanha...) e o lado subjetivo, singular e íntimo de cada observador (DIAS, 2007).

Espaços se constituem então a partir de duas esferas: uma material, representada pelas formas e objetos que compõe a paisagem e outra simbólica que a cargo da sociedade carrega a paisagem de funcionalidade. Paisagem é sempre possibilidade, espaço e lugar são ação!

A vida dos homens nesse ambiente compôs a memória desse lugar, dotando-o de história e alma. Tentar fazer que seja vivenciada a alma desse lugar e a partir disso, fazer parte dessa história, é admiti-lo como um todo, tanto os aspectos materiais quantos os simbólicos do espaço visitado. É preciso que a visita ao sítio arqueológico Bisnau, estabeleça-se de modo que sejam diversas as experiências dentro desse processo, para que mais percepções sejam desencadeadas, aumentado a possibilidade de atingir imaginários, gerar imaginação e consequentemente que o sujeito turista estabeleça alguma relação com este espaço. O turismo precisa proporcionar experiências que instaurem o trânsito dos paisagens visitadas em lugares vividos. 
Milton Santos (2002) estabelece o conceito de paisagem para desvelar o passado no presente. Segundo o referido autor "A paisagem é um conjunto de formas que, num dado momento, exprime as heranças que representam as sucessivas relações localizadas entre homem e natureza. O espaço são as formas mais a vida que as anima" (SANTOS, 2002).

No turismo, o marketing turístico veicula várias paisagens (praias desertas, por exemplo), tentando produzir/atingir um imaginário (bucólico) afim de que estas paisagens sejam visitadas/experimentadas. É importante - para indústria turísticaque essa experiência estabeleça em sua maior parte uma correspondência entre a paisagem imaginada e o espaço vivido. $O$ imaginário preenche a paisagem de "memória" - a memória do lugar é minha memória - a experiência física a anima, lhe dá vida.

A história da região do complexo arqueológico do Bisnau demonstra, a partir das cicatrizes deixadas na paisagem, como no lajedo ou no abrigo da Capetinga, ou ainda nos rios, matas e cachoeiras que certamente marcaram e marcam as relações dos homens com estes espaços, o estabelecimento de um lugar de memória, que seguidamente foi habitado tomando o espirito das culturas que com esse ambiente se relacionam.

Essas características apresentadas são dinâmicas e engendradas pela cultura do diversos povos que ali viveram e pelos sujeitos que hoje de alguma forma experimentam esses espaços seja de forma cotidiana ou pautada no estranhamento como é o caso do turismo. Dessa forma as relações perceptivas desse ambiente variam de sujeito para sujeito de grupo para grupo.

A paisagem, animada pela experiência turística, cria um espaço turístico que por sua vez pode ser vivido em diferentes intensidades pelos diversos indivíduos que o preenchem de vida. Quando essa relação estabelece um alto grau de envolvimento entre o sujeito que visita e o espaço visitado carregando esse espaço de vivencias e experiências marcantes e assim se estabelece um lugar pra si. 
O sítio arqueológico Bisnau é então uma paisagem, localizada num espaço geográfico, sob coordenadas especificas, e que pode desempenhar hoje uma "função" (SANTOS, 2002) turística. A atividade turística é caracterizada pela experiência do homem no mundo e é essa experiência nos seus mais variados degrades que vai compor os espaços e lugares turísticos.

Assim, para além da visita no lajedo do Bisnau ou na Toca da Onça da Capetinga, as potencialidades de experiência turística devem ser agregadas, por exemplo, à cachoeira do Rio Bisnau, à gastronomia goiana no frango com pequi e a pamonha da Pamonharia do Bisnau, as prosas e causos da comunidade. Esse conjunto, possível de ser vivido, deve fazer parte de um roteiro. Os aspectos naturais, materiais e imateriais, conjugam a alma do lugar, a ocupação milenar nesse lugar o reveste de memória que pode ser vivida e transformada pela experiência turística. 


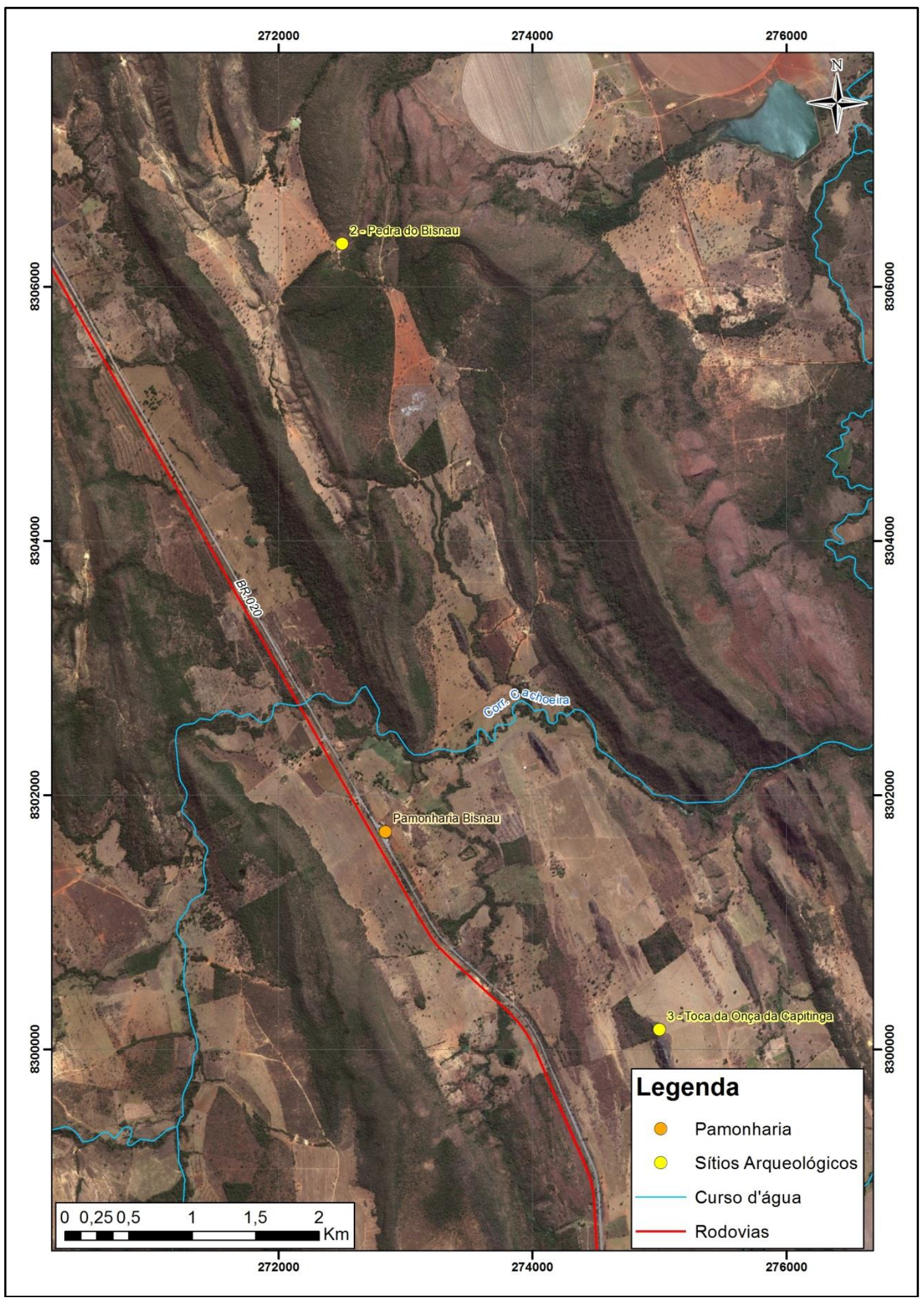

Figura 8: Pamonharia do Bisnau e Sítios Bisnau e Toca da Onça da Capetinga 
A experiência turística ao sítio Bisnau, portanto, extrapola os limites do lajedo rupestre apresentado como atrativo único da visita. É preciso deixar claro como a história do lugar pode contribuir para a experiência turística de natureza integrando possibilidades, agregando potencialidades antes diminutas e que podem compor uma rede complexa de sensações, partindo de uma eco-história ${ }^{16}$ do lugar.

O sítio arqueológico Bisnau foi, e é parte de um complexo arqueológico que abrange tanto espaços culturais quanto naturais. Os ambientes naturais da região, como a cachoeira do rio Bisnau, são entendidos aqui mais que por suas características físicas e geográficas, mas também pelas relações subjetivas e afetivas que podem se estabelecer quando da experiência nesse lugar.

\subsubsection{Espaço, Lugar e Tempo}

É importante tratar de outra esfera fundamental em todo o processo de entendimento dos conceitos de lugar e espaço. O tempo. Para os dois conceitos, o tempo, é fator preponderante.

Um sujeito para se localizar no mundo depende muito mais que uma referência unicamente espacial. $O$ individuo que admite estar atuante, revelando suas ações, anseios e conquistas, ou seja, criando sua história, necessita fundamentalmente de um referencial temporal, que se revelará, no caso do turismo, a partir do estranhamento. O sítio arqueológico Bisnau, lócus dessa pesquisa, revela marcas na paisagem que de maneira lógica localizam o visitante num tempo futuro às marcas, pelo simples fato de que estas já estavam ai no momento da experiência.

Nesse momento munido de referencia espacial e temporal refletimos e conseguimos projetar o futuro. É essa a relação entre tempo e espaço. É a própria evolução histórica do homem.

\footnotetext{
${ }^{16}$ Relação íntima entre as ações humanas nos espaços naturais onde estes se estabelecem.
} 
Um fator importante para se definir turismo é sem sombra de duvida o tempo. Várias discussões já foram levantadas. É preciso quanto tempo para se fazer turismo? Existe um período de tempo necessário entre as relações homem-mundo para que estabeleça espaços, lugares ou até mesmo para que o turismo aconteça?

O espaço então, para além de uma definição geométrica ou essencialmente física, é uma trama, em que brota, revela o passado no presente, mas também, é palco para as experiências no presente e das ações futuras.

O espaço carrega uma transversalidade de tempos e memórias que se substancia nas várias paisagens captadas por nós. O individuo que no presente atua no espaço deixa sua marca e interpreta a marca do outro a partir de suas vivências e experiências que estão ancoradas no imaginário.

Cassab (2008) ao realizar um panorama do conceito de espaço nas obras de Milton Santos, explica que para ele, "o espaço é também o encontro entre passado e futuro, mas é, antes de tudo, presente, pois são as relações sociais do presente que cristalizam e/ou substituem os momentos e ações passadas, bem como projetam o futuro" (CASSAB, 2008). "O espaço é o resultado de uma acumulação desigual de tempo" (SANTOS, 2002).

Assim a relação entre espaço e tempo é diacrônica, pois, neste espaço estão contidos vários tempos, entretanto, na mesma mediada é substrato para ação humana no presente.

O tempo, como conceito e fator fundamental para o entendimento e interpretação do que seja espaço - àquele que traz o homem a cena - também o é para a compreensão do conceito e definição de "lugar". Lugar, para além de sua magnitude geográfica e, que produz um sentido de localização, tem mais uma vez o homem enquanto sujeito atuante que se relaciona com o mundo e configura este enquanto lugar. Um lugar se estabelece para um sujeito quando este experimenta determinado espaço e, essa experiência cria um vinculo de afetividade entre o sujeito que vive e o espaço vivenciado. Sendo assim, um lugar faz referencia à "tipos de experiência e envolvimento com o mundo, a necessidade de raízes e segurança" 
(Relph, 1979 apud LEITE, 1998). Trata-se, portanto, em criar "referenciais afetivos os quais desenvolvemos ao longo de nossas vidas a partir da convivência com o lugar e com o outro" (LEITE, 1998).

A palavra convivência, extraída do texto acima, traz um sentido de continuidade temporal da nossa experiência num lugar. Criar afeto por um lugar ou coisa, normalmente não se circunscreve num período de tempo efêmero e passageiro, entretanto, é possível que haja um encantamento a "primeira experiência". Tuan (1975) estabelece uma relação intima entre o tempo e a experiência nesse processo. Esse autor destaca que para se ter o senso de lugar leva tempo de relação com o mesmo para que assim haja envolvimento.

O lugar torna-se realidade, portanto, a partir da nossa familiaridade com o espaço, não necessitando, entretanto, de ser definido através de uma imagem precisa, limitada. Lugar se distingue, deste modo, de espaço". Este "transforma-se em lugar à medida que o conhecemos melhor e o dotamos de valor" (TUAN, 1983) adquirindo definição e significado (Ferreira).

TUAN (1980) traz outro conceito nomeado de TOPOFILIA, que seria o relacionamento e a experiência de um individuo num lugar que despertaria sentimentos de ternura e afetividade. Por outro lado outros autores (GUIMARÃES, 2002) fala que esse relacionamento pode causar um sentimento de aversão ao lugar, por um trauma ou fobia, denominando-o de TOPOFOBIA.

Tuan (1975), afirma ainda que há uma estreita relação entre experiência e tempo, na medida em que o senso de lugar raramente é adquirido pelo simples ato de passarmos por ele. Para tanto seria necessário um longo tempo de contato com o mesmo, onde então houvesse um profundo envolvimento. No entanto, seria possível a um indivíduo apaixonar-se a primeira vista por um lugar tal qual por uma pessoa (Tuan, 1983). Em contraste, uma pessoa pode ter vivido durante toda a sua vida em determinado local e a sua relação com ele ser completamente irreal, sem nenhum enraizamento. 
Paul Ricour e Michel de Ceteau acreditam que o passado consubstancia-se no presente através dos rastros, dos vestígios deixados que, independente do tempo e do lugar, fazem-se presente de várias maneiras, seja através dos testemunhos escritos, arqueológicos, seja dos testemunhos orais fixados pela escrita (BRANDIM, 2010).

O defrontar-se com o registro rupestre representa uma interceptação do passado no presente, entretanto, o passado percebido por um sujeito é produto do seu imaginário individual/coletivo e que não necessariamente vai situar esse passado num período arqueológico. Contudo, essa transgressão é chave para nos referenciarmos no mundo. Estar presente é estabelecer um passado e projetar o futuro.

O registro histórico é um discurso da presença do faltante, uma forma de túmulo que exorciza aquele que não existe mais. Esta forma de registro ou de presença da ausência permite uma forma de localização do sujeito no presente de forma a situarse com relação ao passado de maneira a apropriar-se dos seus significados que serão responsáveis pela continuidade das experiências. (BRANDIM 2010)

Assim, se a escrita é túmulo para aquilo que foi, serve também de lugar do significante que provém de significados, o passado aninhado no presente.

O espaço, portanto, é o palco de ação

Milton Santos (1982) ao tratar da irrupção do tempo passado no tempo presente nas formas do espaço, levanta o conceito de rugosidade, ela seria o instante de transição entre uma paisagem carregada de forma que Ihe dão história e memória e o espaço, palco da ação presente. As rugosidades seriam produtos de legados históricos exibidas em suas formas, entendê-las é essencial "porque elas são o envoltório inerte dos instantes que marcam a evolução da sociedade global, mas, igualmente, a condição para que história se faça" (SANTOS, 1982). 
O sítio Bisnau apresenta essa rugosidade em sua materialidade, revela o tempo expressado nos desenhos. Essa materialidade desempenha hoje uma funcionalidade turística e poder ser experimentada e vivenciada. A vivência desse espaço, juntamente com a vivência de outros espaços e lugares durante todo o trajeto turístico vai formatar um espaço turístico.

\subsection{O Espaço Turístico}

A dinâmica turística é interessante para entender o fluxo entre as instancias espaciais: espaços e lugares numa perspectiva da experiência do sujeito no mundo mediada pelo imaginário. A paisagem turística quando vivida em ato se transforma num espaço turístico no substrato do espaço geográfico que lhe dá referencia espacial.

Qual seria então a relação entre Espaço turístico e Espaço Geográfico? É preciso então definir o Espaço Turístico como sendo um recorte do espaço geográfico a partir da experiência turística, no nosso caso no sítio arqueológico Bisnau Formosa, Goiás. Enquanto recorte, comporta o todo e, por isso faz parte do todo.

O espaço turístico como apresentado por Castrogiovanni (2007), tem sua constituição alicerçada do espaço geográfico, bem como é composto por espaços e lugares que o turista irá vivenciar. Em sua viagem o turista terá de deixar seu lugar habitual - casa, família, amigos - para experimentar outros espaços, não cotidianos. No entanto, este mesmo espaço, estranho aos olhos do visitante é o lugar da comunidade receptora.

O turismo arqueológico aqui apresentado tem como atrativo principal o lajedo rupestre. Todo imaginário trabalhado acerca desse espaço, seja o discurso cientifico, os relatos e mitos da comunidade e diversas outras versões para explicar as gravuras servem de potencial fator de interesse e curiosidade, o que pode desencadear um desejo de visita.

Esse é o outro campo relevante para construção de um espaço turístico, a comunicação. Ela serve para delimitar um espaço turístico de um espaço geográfico. 
A comunicação turística se vale, no caso do sítio arqueológico Bisnau, principalmente do imaginário místico e milenar que as figuras representam. Não podemos comunicar o espaço turístico sem conhecimento do processo histórico de formação do Espaço Geográfico, só assim parece ser possível compreendê-lo (CASTROGIOVANI, 2007)

É sabido que a construção de um espaço turístico quando planejado visando a maior margem de lucro e exploração dos recursos terá como consequência uma comunicação voltada para o consumo, podendo gerar o fluxo exagerado de turistas, sobrecarregando o destino e tornando-o obsoleto ou destitui-lo de sua singularidade.

O espaço turístico é (re)(a)presentado/(re)construído pelos processos de comunicação (CASTROGIOVANI, 2007). Essa comunicação é ao mesmo tempo produto e combustível de imaginários. O espaço turístico é, portanto, uma construção social, que agrega o concreto e o abstrato envolvidos no fenômeno turístico. Configura uma rede de fluxos e permanências dos homens nos espaços mais ou menos simbólicas que são reveladas, mantidas ou alteradas, através da comunicação.

Essa malha de espaços e lugares quando vivida com um propósito de se fazer turismo, conforma um espaço turístico, desenhado dentro de um espaço geográfico. As funcionalidades que as paisagens nos determinam quando experimentadas serão carregadas de conteúdo, a partir do nosso conhecimento, bagagem, conduta, ou seja, segundo nosso imaginário individual/coletivo compartilhado em grupo e/ou pela sociedade.

Um bom exemplo seria uma ordenação turística, ou seja, um plano estratégico de turismo. Tal ordenação é a busca conveniente dos meios existentes no espaço turístico para o sucesso das propostas relativas às atividades turísticas. Dessa forma, os planejadores de marketing turísticos se valem dos recursos e potencialidades de um espaço turístico e constroem os famosos roteiros, verdadeiros ritos nem sempre toleráveis. 
Castrogiovani (2009) ao relatar sobre a experiência de um sujeito em um espaço turístico declara que:

[...] o Espaço Geográfico é palco para a substantivação do Espaço Turístico. A experiência do sujeito num espaço turístico pode ser mais ou menos carregada de sentidos e sentimentos o que vai provocar a criação/alusão de lugares, não-lugares e entre-lugares os quais por sua vez compõe esse espaço turístico.

Assim como visto no tópico "Espaço e Lugar" dessa dissertação, o espaço turístico quando praticado, revela lugares a partir dos sentimentos trocados com o meio.

Espaço turístico é um conjunto formado pelo espaço geográfico que lhe dá palco e de lugares, não-lugares e entre-lugares que lhe dão vida.

\subsubsection{Lugares, Não-Lugares e Entre-Lugares do Espaço Turístico}

Os dois últimos conceitos - não-lugares e entre-lugares apresentados serão elucidativos às questões relativas ao entendimento da apropriação de um espaço turístico e suas possibilidades de torná-lo um lugar para o turista mediado pela experiência afetiva.

O não-lugar seria a negação do lugar, entretanto, que ocorre de maneira quase intuitiva. Apesar de ser também uma construção humana a experiência do sujeito que Ihe dá vida é pouco carregada de relações estreitas e enraizamento. Para Augé (1994):

O Não-Lugar pode ser tanto as instalações necessárias à circulação de pessoas e bens (vias expressas, trevos rodoviários, aeroportos) quanto os próprios meios de transportes ou os grandes centros comerciais, ou ainda os campos de trânsito prolongado onde são estacionados os refugiados do planeta (AUGÉ, 1994 apud CASTROGIOVANI, 2009).

Dessa forma os não-lugares são alguns dos meios em que o turismo acontece, porém, não é única medida para que esse fenômeno se estabeleça ou seja entendido.

No entanto: 
O Espaço Turístico pode ser analisado sob diferentes orientações, como, por exemplo, o espaço do emissor/Lugar, onde vive o turista e, o espaço do receptor/Lugar que o turista busca. Para nós, há possibilidade de haver um outro espaço turístico - o espaço intermediário, ou seja, o entre-espaço ou Entre-Lugar turístico.(CASTROGIOVANI, 2007)

O entre-lugar, assim como um não lugar ,pode ser entendimento como passagem, como uma instância espacial de transição, porém, às relações entre homem e espaço são menos superficiais, são dotadas de sentimentos que carregam esse espaço das propriedades de um lugar. Como afirma Castrogiovani (2009) o EntreLugar turístico pode ser entendido como:

Sendo a lugarização do Espaço Geográfico, substanciada pelo Sujeito visitante na dialogicidade estabelecida entre o seu Lugar (Lugar conhecido) e o Lugar/Não-Lugar visitado (desconhecido). Ele é simbólico, enquanto existência, mas possui uma densidade representativa, a partir da Cultura. Portanto, depende das incorporações tempo-espaciais do Sujeito visitante. Ele confunde o Lugar de origem com o Lugar/Não-Lugar visitado. Com a sua constituição, este sub espaço passa a ser uma parte do todo que é Espaço Turístico (CASTROGIOVANI,2009)..

O espaço turístico emerge então das diversas experiências humanas no espaço e na sociedade se encerrando nestas a possibilidade de pensar esses conceitos.

No espaço turístico do sítio arqueológico bisnau vários atrativos podem se tornar um lugar turístico para o sujeito que o visita. O lajedo rupestre, a cachoeira, a pamonharia, estes são todos espaços possíveis de visitação e passiveis de troca e relacionamento profundo. Caberá a cada indivíduo que se desloca pelo espaço turístico do sítio Bisnau estabelecer lugares e não-lugares e é nesse processo que se encontra o entre-lugar turístico. 


\subsection{O Imaginário Na Experiência: Construindo Versões Sobre O Sítio Bisnau}

A intensidade da experiência do homem no mundo que desvela os lugares no espaço depende do imaginário de cada sujeito e, que será projetado na vivencia de determinado espaço, o qual por sua vez será percebido através da intencionalidade da consciência do indivíduo que parte do imaginário. Vai variar de acordo com as percepções do sujeito, as percepções registradas, por sua vez, serão decodificadas intencionalmente pela consciência tendo o imaginário invidual/coletido como mediador desse processo.

Já vimos como a experiência, o estar no mundo é preponderante nas relações do homem com os espaços e lugares, é de ser sabido também que nossas experiências partem de intencionalidades da nossa consciência o que por sua vez é um produto do imaginário. Quais então as relações que se estabelecem entre essas esferas e conceitos - experiência, imaginário, espaço e lugar - no âmbito da experiência turística ao sítio arqueológico Bisnau?

A experiência de um sujeito, que vivencia e percebe o mundo, parece ser uma faceta importante do processo da mutação de um espaço (acumulação de tempos) em um lugar (acumulação de vivencia e afetividade).

Partir-se-á então, do levantamento dos relatos dos visitantes, da comunidade, entre outros atores, ou seja, da externalizaçao de parte da sua realidade vivida ou de vida para entender um pouco mais desse processo e das transformações contínuas das paisagens, dos espaços e dos homens envolvidos nessa experiência no mundo.

Entendo que possam existir diversas possibilidades de experiências com o meio em um espaço turístico, no entanto, a valorização de um ou outro espaço é dado por cada individuo, ao passo que um mesmo atrativo pode despertar a sensibilidade em mim e não em qualquer outro.

Percebemos então, por meio das entrevistas, como esses lugares e não-lugares foram estabelecidos a partir da experiência do sujeitos na visitação ao sítio arqueológico Bisnau. Esse entendimento partiu das análises das narrativas dessas vivencias. 


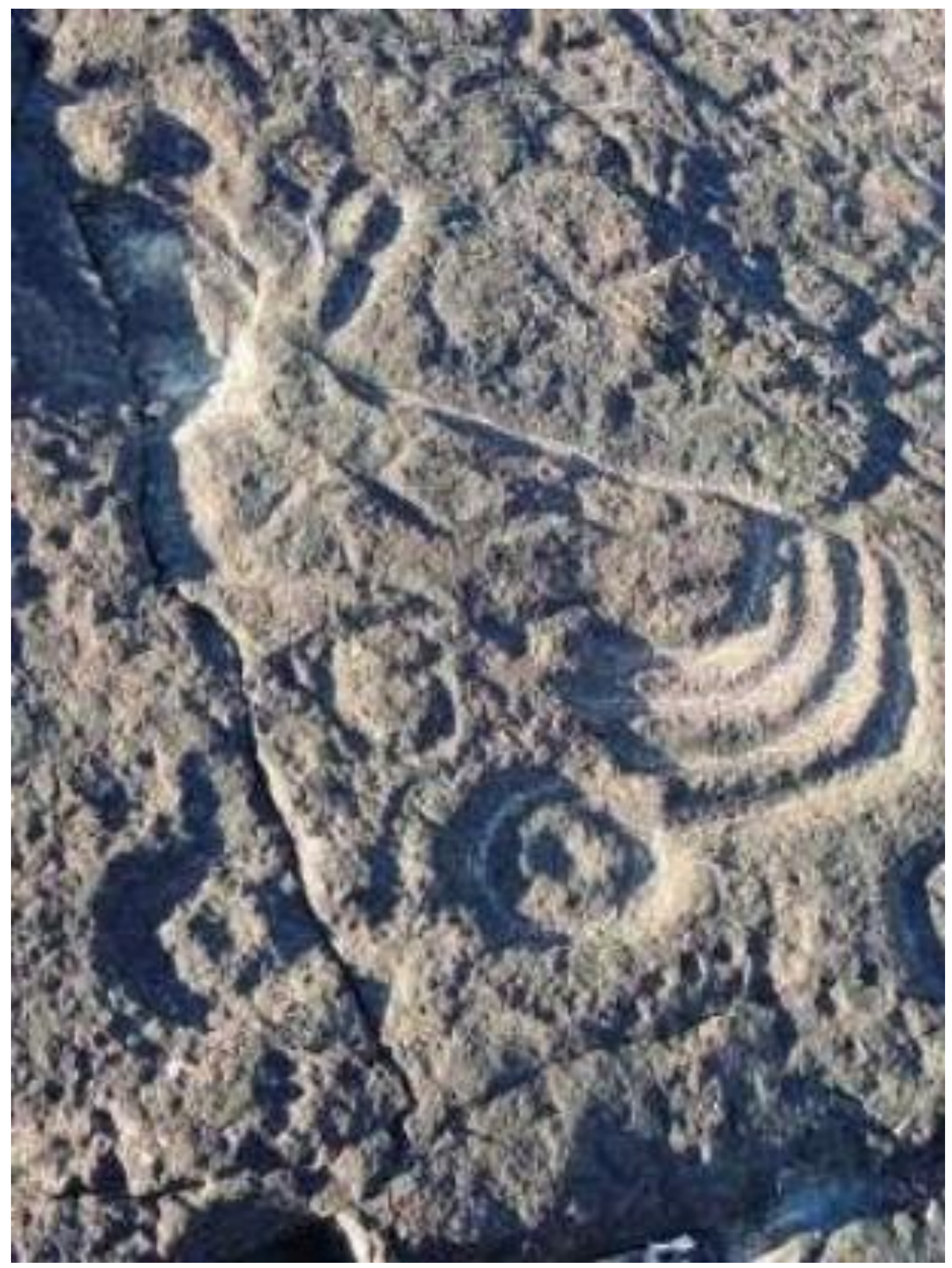




\section{ENTRE-VISTAS}

A entrevista foi a técnica utilizada para coleta de dados que suprissem a análise da problemática reconhecida no início da pesquisa. Para Carlos Gil (1987) a entrevista pode ser definida "como a técnica em que o investigador se apresenta frente ao investigado e the formulam perguntas, com o objetivo de obtenção dos dados que interessam à investigação" (GIL, 1987).

Quando vivenciamos um espaço turístico podemos desencadear relacionamentos mais ou menos profundos com estes espaços. Essa relação vai levar à possíveis vínculos ou desapresso dos espaços visitados, criando sentimentos que serão materializados em parte, através das narrativas dessa experiências. Essas narrativas do mundo experimentado irão suplantar a manutenção ou a criação de imaginários. O movimento parece circular. Narrativas criam imaginários que por sua vez criam narrativas que influenciarão nas experiências conceituais ou corpóreas modificando os espaços e os indivíduos que, a partir disso, se posicionam no mundo, refletem e se direcionam. Suas definições são externalizadas então através de suas atitudes e narrativas. Para Selltiz (1967):

A entrevista é bastante adequada para a obtenção de informações acerca do que as pessoas sabem, creem, esperam, sentem ou desejam, pretendem fazer, fazem ou fizeram, bem como acerca das suas explicações ou razões a respeito das coisas precedentes (SELLTIZ, 1967 apud GIL, 1987).

As entrevistas realizadas registraram as narrativas dos visitantes e levantou os relatos sobre a experiência vivida, sendo esse processo a ferramenta para alcançar a realidade percebida. Esses relatos vêm acompanhados de uma carga de sentidos e sentimentos do fato narrado, o que nos parece ser o link para instauração de "um lugar" experimentado. 
Atribuímos sentido ao mundo quando nos expressamos sobre ele, quando relatamos nosso percurso. Dessa forma nossas narrativas são "relatos de espaço" que compõem o que conhecemos ou identificamos ou representamos como real (SOCHODOLAK E OLIVEIRA, 2012).

As entrevistas, portando, tiveram o objetivo de coletar os relatos da experiência e vivencias influenciadas pelo imaginário, que em diferentes momentos os atores envolvidos tiveram na relação com o sítio arqueológico Bisnau e perceber as relações que essas pessoas tiveram com os espaços durante toda a visita. Foram coletadas também as versões do que seriam alguns dos motivos encontrados no lajedo e as possíveis razões de ser e estarem ali. Essas versões compõem um glossário apresentado adiante com as diferentes possibilidades de percepção das figuras rupestres.

As entrevistas coletaram informações de seis pessoas pertencentes a grupos e classes sociais diferentes e foram realizadas por pautas. A captação dos relatos foi feita por meio de câmera de áudio e vídeo.

Foram definidos três grupos compostos de dois integrantes cada. O primeiro grupo representou pessoas mais próximas do pesquisador e que, portanto, tinham conhecimento, ainda que diminuto, da atividade desenvolvida, estes foram definidos como Ator 1 (A1) do Grupo 1 (G1) e Ator 2 (A2) do Grupo 2 G(2). O segundo grupo $^{17}$ foi representado por pessoas desconhecidas do pesquisador, mas que estavam interessadas em conhecer um sítio arqueológico, denominados então como A1 - G2, ou seja, Ator 1 do Grupo 2 e A2 - G2, Ator 2 do Grupo 2. Por fim, foram ouvidas pessoas residentes nas redondezas do sítio arqueológico Bisnau e que então tem envolvimento seja pelo turismo seja pela riqueza/raridade que se encontra em seus quintais. Estes foram denominados A1 - G3 e A2 - G3.

\footnotetext{
17 A primeira vista esse grupo representa o único grupo de turistas, pois partiram de ações deliberadas para se deslocarem. Seguiram seus desejos e anseios. Diferentemente dos dois outros grupos. No entanto, que também trouxeram informações relevantes para o estudo.
} 
Procurou-se angariar os relatos de diferentes indivíduos, pertencentes a diferentes núcleos sociais. Restringir a coleta de dados a um só grupo de turistas - que normalmente partilham um imaginário comum, pertencentes a uma mesma "tribo" poderia resultar em pouca diversidade de versões sobre o sítio visitado.

\title{
5.1. Grupo 1
}

O primeiro grupo partiu da cidade de Formosa, Goiás por volta das 14:30 horas depois de ser ouvido formalmente e informalmente e indagado acerca de perguntas pré-formatas que também foram dirigidas aos demais grupos, a saber: O que é um sítio arqueológico pra você? O que você imagina encontrar? Você consegue explicar como surgiu esse sítio arqueológico? Você já visitou um sítio arqueológico? .

A seguir a transcrição das respostas das perguntas acima referidas:

Para você, o que é um sítio arqueológico?

\begin{abstract}
A1-G1: Bom, para mim, sítio arqueológico é uma área, ou um conjunto de áreas onde pode se encontrar intervenção humana, intervenção no passado, como por exemplo, antigos cemitérios ou alguma coisa que se identifique vestígios da intervenção humana no passado, seja ele préhistórico ou não.
\end{abstract}

A2-G1: Sítio arqueológico é um lugar que já foi habitado e tem evidências dessa residência humana.

O que você imagina encontrar?

A1-G1: Bom, pelo conhecimento que eu já tenho da área, eu acredito que figuras rupestres mesmo, mas se fosse uma área desconhecida, que eu tenho em mente que é um sítio arqueológico, poderia encontrar ponta de flecha, alguns resquícios de cemitério, né, dessas intervenções humanas.

A2-G1: Não, não tenho nenhuma expectativa muito clara do que encontrar por lá. 
É perceptível nesse grupo, que seus atores já tinham algum conhecimento sobre sítios arqueológicos e alguns elementos que constituem esses espaços. Os relatos acima demonstram que estes compartilham um imaginário do sítio arqueológico tal qual as narrativas cientificas o fazem, referenciam a arte rupestre do lajedo do Bisnau à populações pré-históricas que viveram na região em tempos pretéritos.

Você consegue explicar como surgiu esse sítio arqueológico?

A1-G1: Assim, o que eu imagino é que são intervenções de povos antigos, mas não tenho mais conhecimento.

A2-G1: Talvez quisessem deixar um registro de que já ocuparam aquela área e ter esse registro da ocupação.

O primeiro excerto acima nós parece interessante para a pesquisa, o que se imagina, ou seja, o imaginário acerca do sítio arqueológico, nada mais é que bagagem de cada um, seu conhecimento. O entrevistado imagina "que são intervenções humanas", "mas não tem mais conhecimento sobre".

Você já visitou um sítio arqueológico?

A1-G1: Não!

A2-G1: Sim. Em Rondonópolis, Mato Grosso.

Dessa forma, os dois atores do primeiro grupo já estavam imbuídos de algum conhecimento prévio acerca de espaços arqueológicos, no entanto nunca haviam visitado o sítio arqueológico bisnau, sendo que um deles jamais visitou nenhum. Foi definido que deveríamos registrar mais que a visita ao lajedo do sítio Bisnau, mas todo o trajeto, mesmo de maneira informal.

De Formosa-GO até o sítio Bisnau foram $45 \mathrm{Km}$ de pouca conversa e quase uma hora ouvindo as rádios locais. A riqueza da paisagem durante o percurso, revelando 
vários paredões de calcário e algumas pontes um tanto precárias na chegada ao sítio, foram os principais responsáveis pelos diálogos.

A chegada ao lajedo provoca diferentes reações nos indivíduos que se relacionam com esse espaço, uns expressam espanto, outros incredulidade, outros já propõe uma forma possível para a confecção de tais desenhos. Ouvíamos a todo tempo afirmações do tipo: "Isso é impossível de fazer", "Mas como eram desocupados", "Isso só pode ser coisa de extra terrestre", ou possibilidades: "Será que esfregavam uma pedra na outro?".

Ficamos por um tempo sobre o lajedo. Ao mesmo passo que localizávamos e tentávamos identificar e interpretar aqueles desenhos, éramos contemplados pelo barulho da natureza - com todos seus zumbidos e zunidos - e pelo sol que cobria a vegetação a nossa frente e nos poupava numa sombra integral por todo lajedo.

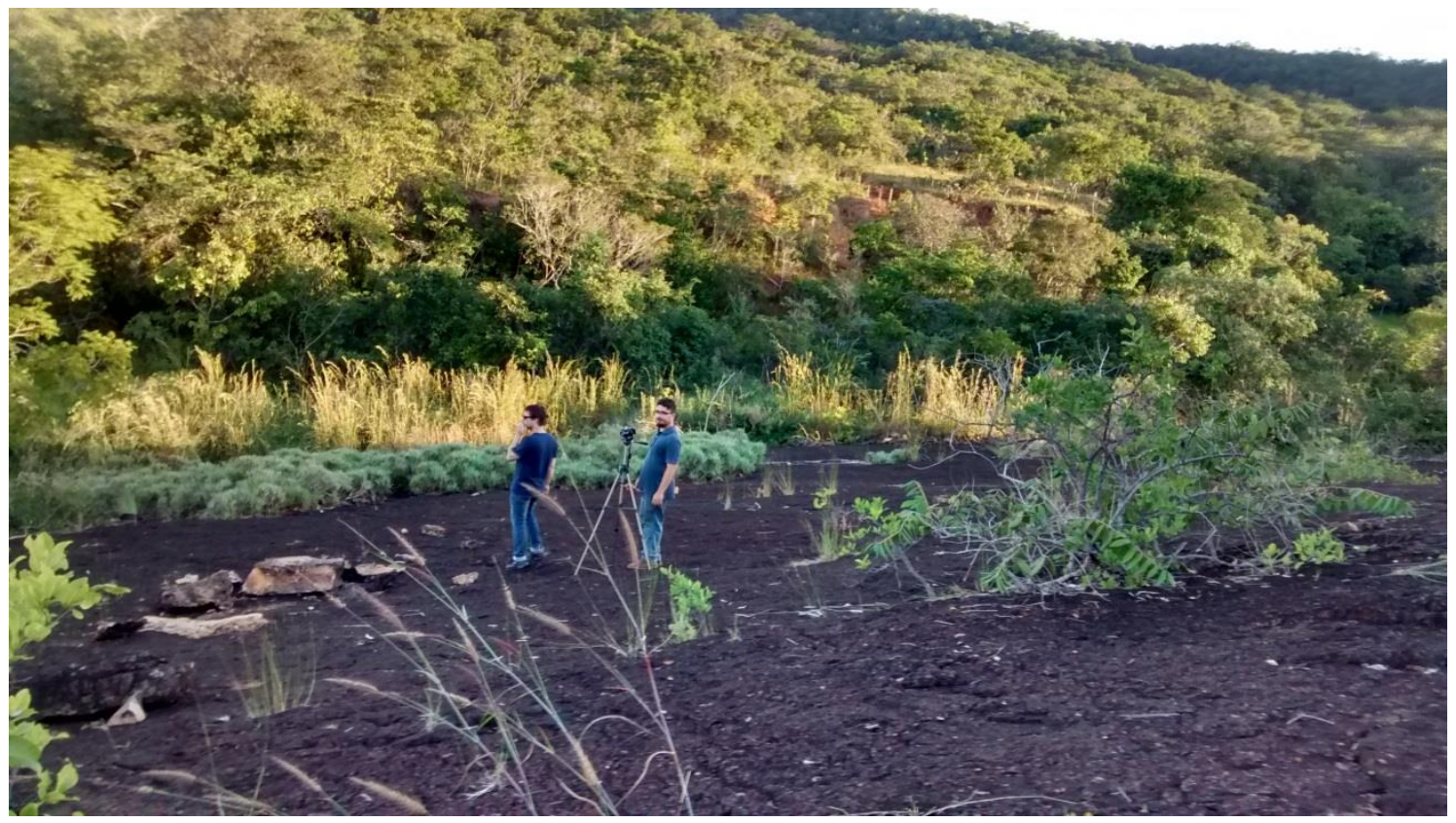

Foto 15: Sol na paisagem e sombra no lajedo.

Por volta de cinco da tarde, foi iniciada nova série de perguntas estruturadas: O que você imaginava sobre o sítio ou o que encontrar nesse espaço mudou após a visita? Qual sua interpretação acerca da figuras? 
Para as duas perguntas as respostas foram positivas. O principal estranhamento declarado foi o de esperar encontrar pinturas ao invés de gravuras.

O que você imaginava sobre o sítio mudou após a visita?

A1-G1: Eu imaginava, por falta de conhecimento, encontrar pinturas, né? E o que a gente viu aqui são inscrições nas pedras, algumas delas a gente tenta decifrar, como alguns pássaros, cobras, né, alguns bichos e alguns homens, seres humanos.

A2-G2: Mudou bastante, porque normalmente a gente tem a ideia de que sítio arqueológico vai ter só pintura, só desenhinho, e são inscrições. É uma rocha bem resistente então se até hoje ainda é possível se perceber alguma coisa, então foi um trabalho bastante difícil, eu esp... eu imagino. E tem algumas coisas que parecem ser sequência.

As experiências desses sujeitos nos diversos espaços e principalmente no sítio Bisnau transformou o imaginado e na mesma medida carregou o imaginário de cada individuo com novos conhecimentos e percepções estabelecidas durante a visita.

Qual sua interpretação acerca das figuras?

A1-G1: São inscrições na rocha, muito voltadas, assim, acho que pro homem e pro animal, o que eu consegui identificar, o que eu imaginei que fosse pelo menos. $\mathrm{E}$ (tosse,)... Alguns círculos, aliás tem vários círculos que eu acho que remetem, assim na minha imaginação até parece, alguns semelhantes ao que a gente desenha hoje como se fossem discos voadores... (pausa, fadiga) Ai eu to cansado, cara, eu corri.

A2-G1: É... Tem alguns personagens humanos, alguns parecem... Tem mais sozinhos... Alguns parecem animais... É... Tem alguma coisa que parece que tá sendo contado, que começa com um e depois vai aumentando... Então, talvez mais personificação e uma contagem de alguma coisa. 
As imagens percebidas e, interpretadas na extensão do imaginário de cada individuo que experimentou o sítio arqueológico Bisnau, foi largamente heterogênea. Estrela, aranha, homem, vaca, alguma representação do espaço, discos voadores, entre outras impossíveis de caracterizar pelo conjunto dos traços, mas apenas destacando essas feições. "Linha ligando vários círculos", "vários círculos concêntricos".

Para além da obtenção de dados unicamente através de entrevistas buscou-se captar por imagens de vídeo e fotografias mais que o superficialmente percebido, mas os gestos que demostravam maior relação e troca com o espaço visitado. As mãos percorrendo o lajedo, a pausa para o descanso e uma conversa sobre as pedras...

Esses atores então tinham certa ideia do que era um sítio arqueológico, portanto, a partir de sua bagagem e memória, este grupo especificamente estava impelido pelo imaginário trabalhado pelo discurso cientifico. A expectativa de encontrar pinturas ao invés de gravuras reflete a quantidade de achados e estudos dessas tuas técnicas de confecção da arte rupestre. A bibliografia encontrada é diagnóstica e apresenta muito mais pesquisas tendo por objeto as pinturas.

\subsection{Grupo 2}

O grupo dois, que anteriormente seria composto por duas pessoas, não foi completado e a entrevista foi realizada apenas com um participante. Tendo em vista essa situação, a visita do dia foi realizada juntamente com um integrante da comunidade.

A visita foi realizada no final da manhã e desta maneira o sol estava praticamente sobre nossas cabeças. A pessoa entrevistada e que representa esse grupo, também apresentou conhecimento acerca do que seria aquele espaço e suas definições se apresentam aos relatos científicos, não narrando em nenhum momento algum imaginário fantasioso ou quimérico. 
O que é um sitio arqueológico para você?

A1-G2: Esses locais que guarda, que preserva os sinais, os rastros das civilizações mais antigas que viveram nesses local, que deixaram alguma forma de, da cultura deles da época.

O que você imagina encontrar?

A1-G2: Basicamente, pelas informações que a gente tem tido, nessa região aqui, encontra mais vestígio de escrita, de desenho desse pessoal que viveu aqui, nessa região. Parece que não tem nada em relação a utensílios, essas coisas assim pelas informações que eu tenho ainda não existe aqui nessa... Não foi preservado esse tipo de dado.

Aqui percebemos mais uma vez que alguns dos entrevistados têm referencia e expectativa de poder encontrar "figuras rupestres" (A1-G1), "vestígio de escrita, de desenho" (A1-G2), no entanto, o que se percebe e que estes não tem o conhecimento das diferentes técnicas de confecção dessa arte rupestre do município, fato constatado nas entrevistas.

O que você imaginava antes da visita mudou alguma coisa?

\begin{abstract}
A1-G2: Não, quando eu vim aqui, eu pensei que a gente ia encontrar mais era, é... Figuras... Pinturas. E o que to notando aqui que é exclusivamente com gravura, né? Detalhes que foram entalhados aqui nessa rocha. E outra coisa que dá pra perceber aqui é o desgaste com o passar do tempo. Como ela foi feita entalhada na rocha e ela tem uma inclinação grande, com o passar do tempo a erosão, pela água da chuva, trazendo areia junto, vai desgastando essas, essas relíquias que ficaram aqui gravadas tanto tempo. Mas eu pensava que o sítio aqui era formado em gruta também e ele é uma estrutura bem diferente. Que a gente não vê local assim que possivelmente esse pessoal habitava, né? Porque normalmente a gente encontra isso muito disso é em cavernas, nesse tipo de local.
\end{abstract}

Esse é o movimento da experiência influenciada pelo imaginário. $O$ sujeito, carregado de valores, conhecimentos e vivências sobre o mundo - imaginário projeta essa carga na futura experiência ("o que eu imagino encontrar" "pelas 
informações que agente tem tido) e quando esta acontece a relação é transformadora. Experiências são os modos pelos quais as pessoas conhecem e reconstroem uma realidade (TUAN, 1977).

Foi essa a relação observada nas entrevistas no sítio Bisnau, ainda que houvesse conhecimento genérico sobre sítios arqueológicos, o espaço imaginado e suas características, foi trabalhado pela experiência in loco, ou seja, no momento da visitação turística.

Qual sua interpretação acerca das figuras?

\begin{abstract}
A1-G2: Não, eu acho que mais ou menos a mesma situação que a gente vê em pintura em caverna, porque, como eu já disse antes, parece que a intenção que o pessoal, na época fazia esse trabalho, era mais uma coisa mais lúdica mesmo, uma coisa mais de passar tempo, não sei se eles tinham intenção de comunicar, ou de deixar preservada a passagem dele pelo local, ou não. Então eu não consegui, realmente, é... Entender... Se é que tem algum sentido, eu não consegui captar. E outra coisa interessante que eu pude notar é que... É que prevalece aqui as formas circulares, né? Às vezes algum tipo de estrela, muito círculo interligado um com o outro, mas basicamente são formas arredondadas, que a gente identifica aqui.
\end{abstract}

\title{
5.3. Grupo 3
}

A entrevista com a comunidade aconteceu por volta das onze horas da manhã do dia 07/05/2015. Esse grupo, apresentou timidez frente as câmeras

As entrevistas captadas por imagem de áudio e vídeo foram substancialmente diminuídas em relação aos outros grupos pela timidez apresentada e possivelmente pelo intuito primeiro desses indivíduos, a relação deles com o turismo propiciado pelo Sitio Bisnau

Apesar disto as conversas informais foram bastante ricas, principalmente no momento da chegada a fazenda que dá acesso ao lajedo do Sítio arqueológico Bisnau em que se deu o encontro com o encarregado das terras, seu João. Logo 
quando chegamos fomos recebidos por ele e seu filho Rafael. Tivemos a certificação de que ali era a entrada para o sítio e começamos uma conversa. Ficou marcadamente claro na fala do seu João que a relação de sua família era estreitamente ligada ao turismo no local. João por várias vezes trazia à nossa conversa relatos dos curiosos ou pesquisadores que passaram por ali.

\footnotetext{
A1-G3: Certa vez veio um estudioso que passou uns três dias lá na pedra, vinha cedo e só ia embora anoitinha. O nome dele era... ah não vou lembrar o nome dele agora, mas é lá de Brasília eu acho.
}

Em muitas das visitas já acontecidas, João acompanhou os grupos e pessoas interessadas em conhecer a pedra do Bisnau, fato que não foi possível dessa vez por motivos pessoais. No entanto pareceu-me excepcionalmente interessante certa passagem na fala dele, onde declara:

A1-G3: É interessante observar como que a cada vez que eu vou lá vejo coisas diferentes, um mesmo desenho parece mudar de formato.

$\mathrm{Na}$ ausência do pai o filho Rafael foi quem nos acompanhou à visita ao Sítio Bisnau. Tímido, respondeu pouco às perguntas, no entanto, mais uma vez ficou destacado, nas suas poucas palavras, a importância do local para ele, seja na atração de turistas, na complementação da renda familiar ou no entendimento que é importante por ser diferente e encantar várias pessoas.

A2-G3: Muita gente só vem aqui pra burriscar os desenhos, olha!"

As relações dos homens com os espaços e os lugares são então relativos, resultado das formas e do contexto que essas práticas acontecem. O sítio Bisnau faz parte do lugar habitual da comunidade, no entanto, para o turista é um entre-lugar, ou seja, um lugar turístico.

Quero destacar que o sítio arqueológico é uma paisagem, um espaço ou um lugar somente quando um sujeito qualquer se relaciona com esse objeto, de qualquer forma. O sítio é paisagem quando vemos imagens do lajedo e somos convidados para a visita. Torna-se espaço quando praticado, e lugar quando esse 
relacionamento traz algo de novo, que acrescente, que nos muda de alguma forma, ou mude a ideia que tínhamos sobre esse objeto. 


\section{INVESTIGANDO AS NARRATIVAS E REVELANDO ESPAÇOS E LUGARES}

Entendo que possam existir diversas possibilidades de experiências com o meio em um espaço turístico, no entanto, a valorização de um ou outro espaço é dado por cada individuo, ao passo que um mesmo atrativo pode despertar a sensibilidade em mim e não em qualquer outro.

Percebemos então, por meio das entrevistas, como esses lugares, não-lugares, foram estabelecidos a partir da experiência do sujeitos na visitação ao sítio arqueológico Bisnau. Esse entendimento partiu das análises das narrativas dessas vivencias.

Tentou-se observar através das mais variadas narrativas - corporais, verbais alguns elementos que pudessem traduzir algum vinculo estabelecido entre as pessoas entrevistadas e os espaços de deslocamento e permanência dentro da visitação ao sítio arqueológico Bisnau.

O primeiro grupo apresentou informações bastante significativas para pensarmos na relação do turista com os espaços. As evidencias buscadas foram reveladas nos relatos e narrativas dos indivíduos e demostraram algumas pistas para entendermos essa prática.

Os entrevistado desse grupo, no entanto, foram os únicos a serem acompanhados e observados desde seus lugares habituais até o atrativo -sítio Bisnau - que motivou a visita. Como explanado anteriormente, partimos da cidade de Formosa-Go em direção a nosso destino, distante cerca de $45 \mathrm{~km}$. O deslocamento realizado de carro pela rodovia BR 0-20 rendeu pouquíssimas conversas, parecia que não estavam lá. Pensamento longe.

Esse deslizar sobre o espaço, involucrado numa gaiola, limita as possibilidades de percepção dos homens, impermeabiliza o fluxo de carga natural entre o homem e o espaço, isola os orgânicos. Esse transcurso se trataria então de um não-lugar 
turístico, pois, não são estabelecidos vínculos entre o homem e o espaço praticado é quase um sonho que não vamos nos lembrar.

Foi interessante reconhecer as relações com os espaços, os lugares visitados, os objetos experimentados e as conversas trocadas a partir das diversas narrativas e linguagens coletadas nas entrevistas, nas filmagens ou em conversas informais no decorrer das visitas.

A captação de vídeo foi fundamental para extrair das experiências mais que os relatos orais, mas toda a manifestação de apatia, aversão ou afetividade em determinada vivência. As mãos que percorrem o lajedo, o olhar fixo no horizonte a fadiga causada pela caminhada, essas expressões só seriam captadas em vídeo e certamente corroboram para analisar a experiência e as relações dos visitantes no turismo ao sítio arqueológico Bisnau.

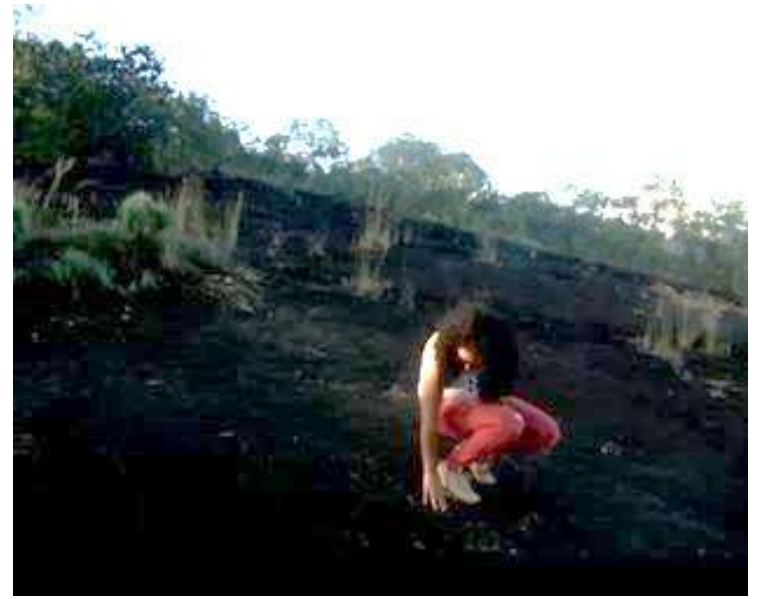

Foto 16: Mãos tateando o lajedo. A2 G1

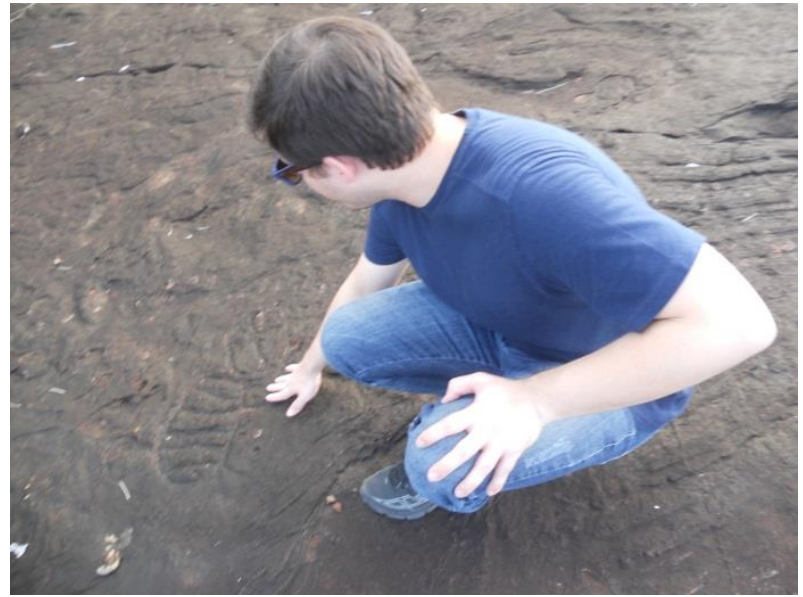

Foto 17: Mãos tateando o lajedo. A1 G1

Essa relação da pratica do espaço pelo homem, que percebendo e o experimentando com intimidade, ou seja, preenchendo-o de sentido, precede uma imediata transformação das pessoas e dos espaços praticados por elas. É nesse movimento de troca com o espaço, quando sentimos o clima, o cheiro, quando nos relacionamos com ele, aí se desvela um lugar no espaço vivido. O turismo possibilita essas transformações dos espaços em lugares pelos turistas que dão vida ao antes desconhecido, carregam o ambiente de forma e conteúdo e levam em suas 
memórias às marcas da viagem, mas antes de tudo, é uma transformação no individuo que experimenta e desvela o lugar.

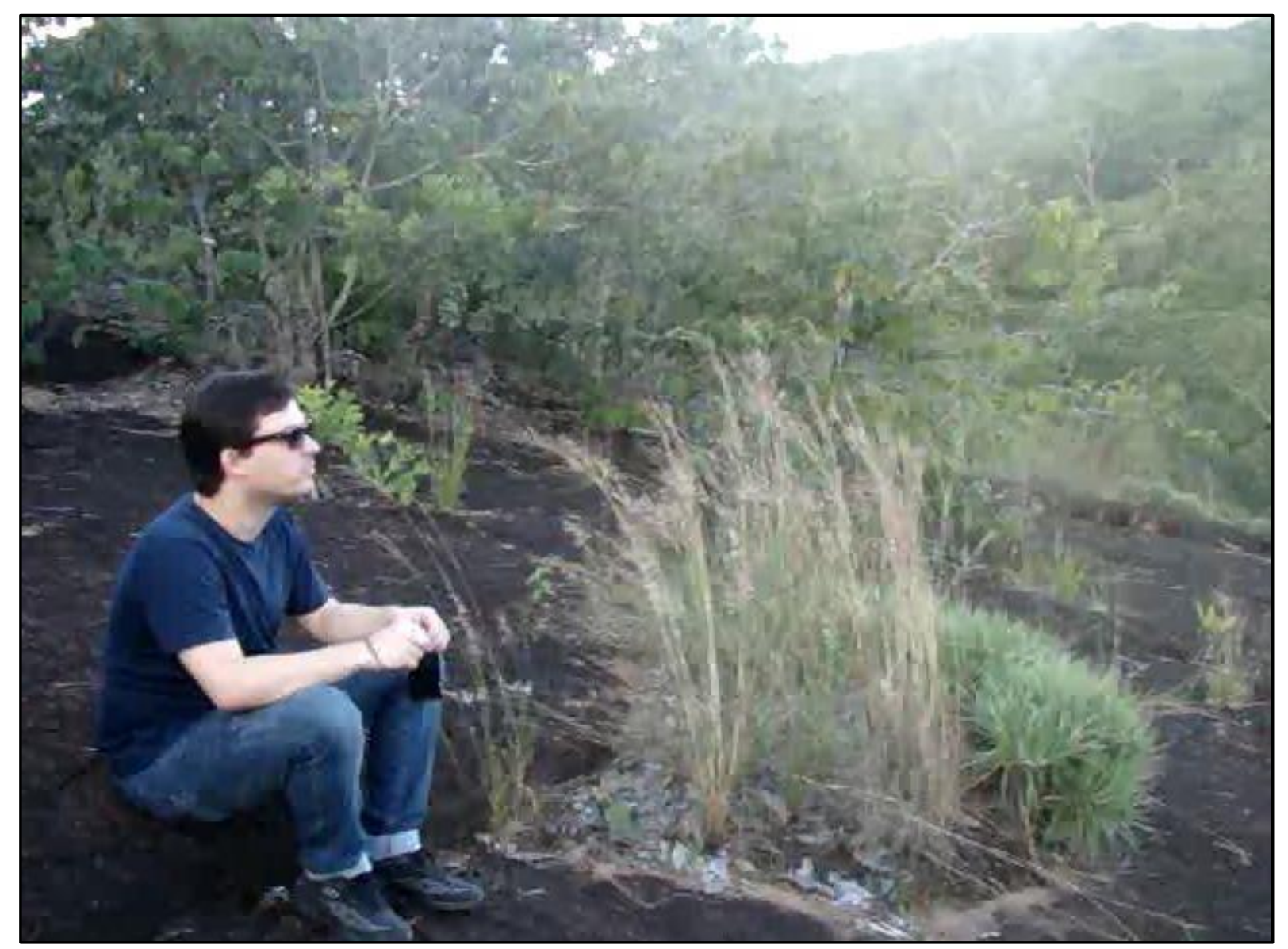

Foto 18: Olhar ao horizonte. A1 G1.

Dentro do espaço turístico do sítio arqueológico do Bisnau outros atrativos podem despertar empatia nos visitantes. A pamonha da Pamonharia Bisnau, por exemplo, fez sucesso. Em momento pós visita um dos entrevistados declarou "vou voltar lá amanhã, mas por causa da pamonha" (A1-G1).

Outro meio responsável por identificar os sentimentos que traduzissem em parte a experiência ao sítio arqueológico foi a internet, principalmente o Facebook. Decorridos alguns dias da visita do Grupo 1 os dois entrevistados "postaram" em suas redes de relacionamento fotos que registraram o momento da visita bem como declaram algum juízo acerca da experiência ocorrida. Estes foram expressos por emoticons. 
A entrevista com a comunidade conserva outro ponto de vista e outra dinâmica relativa aos espaços e ao turismo. O Atrativo turístico - sítio Bisnau -, tratado majoritariamente como "destino" é, para a população circunvizinha ao sítio, componente do seu lugar habitual, ou seja, as relações estabelecidas são outras e o lajedo do Bisnau e mais um objeto do seu cotidiano.

A mensagem passada pelos entrevistados desse grupo é que o sítio Bisnau, bem como a cachoeira, a pamonharia... são atrativos turísticos e que de alguma forma podem servir de fonte para complementar a renda familiar. Trazem, nas suas poucas palavras, o conhecimento apreendido com os tantos visitantes que passaram por ali. Destacam a importância do lajedo Bisnau.

\subsection{Traços, Bichos e Coisas}

Procurou-se, por meio das entrevistas, levantar também as possíveis interpretações dos traços e figuras que compõe o lajedo do sítio arqueológico Bisnau. Os principais relatos se remetiam a animais e seres humanos, no entanto, as figuras geométricas davam extensas margens para imaginação.

A1-G1: "alguns semelhantes ao que a gente desenha hoje como se fossem discos voadores".

A abundância de desenhos geométricos é tanta que parece um quebra cabeça de linhas, círculos e pontos e, a todo instante remexemos o nosso imaginário a fim de nomeá-las, ou seja, dar um sentido para aqueles traços.

A1-G1: Olha só esse parece um bicho. Aqui tem, parece um bicho, olha, tipo um... Com um rabo, tipo um rato, tá vendo? Uma cabeça, um corpo e um rabo? (Aponta as formas, continua observando). Aqui tem um cacho de uva. 


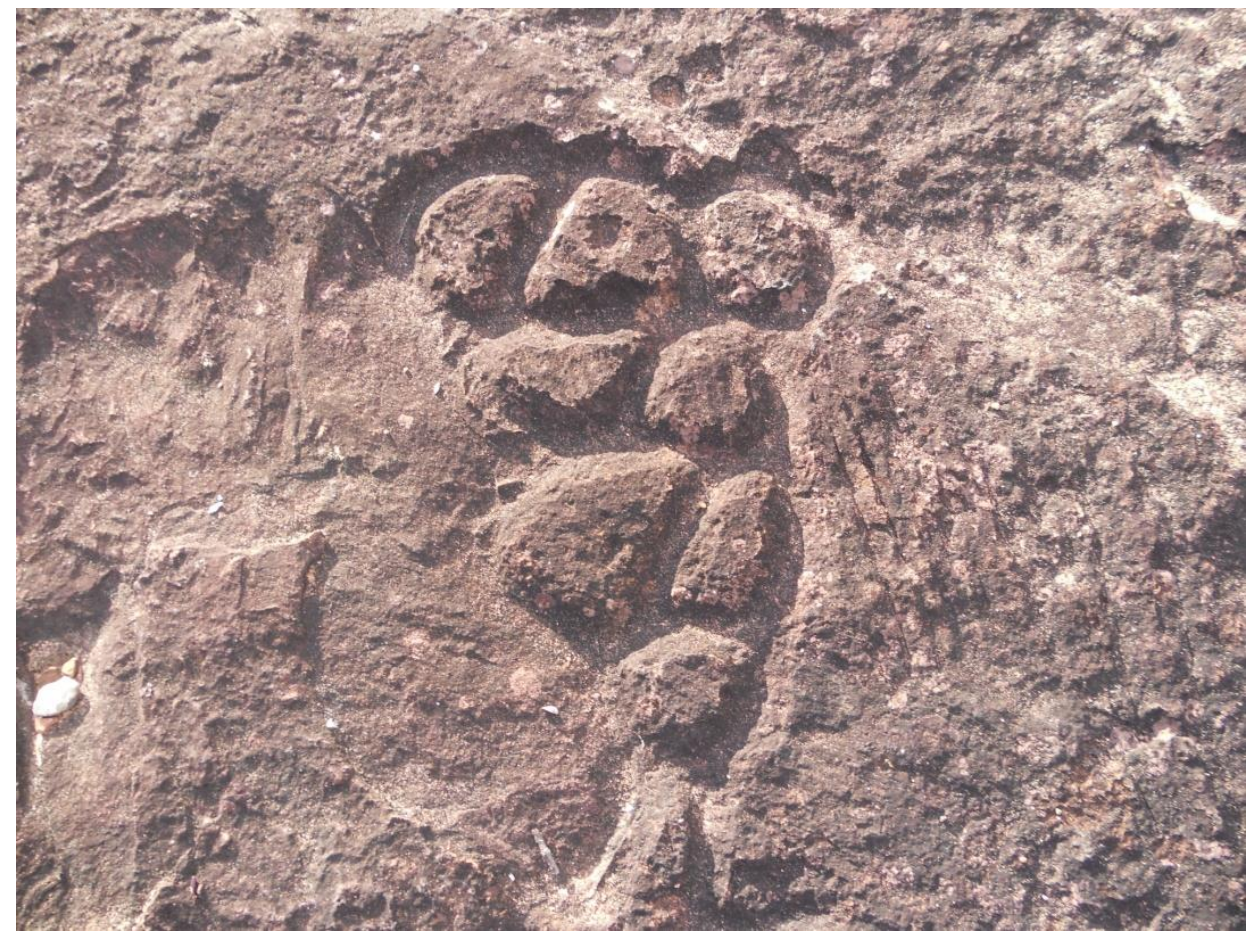

Foto 19: Cacho de uvas.

Os vários traços e formas, parecem se unir e completarem-se, nas várias experiências dos sujeitos no lajedo rupestre. Formam-se figuras humanas, animais entre outros. Essa necessidade de dar sentido às coisas e objetos do mundo é inerente ao ser humano. O desenho acima - cacho de uvas - ao contrário da tentativa de construção/reconhecimento do "rato", foi imediatamente identificado. Isso demonstra como nossa percepção está vinculada também ao dar significado ao mundo, não apenas funcionando como um receptáculo de sentidos.

Percebemos nas entrevistas, que o sentido dado às figuras não foge muito da realidade dos sujeitos envolvidos. A alusão a personagens fantásticos ou surreais, por exemplo, poucas vezes foi levantada.

Toda nossa bagagem de vida, experiências e o modo de estar e ver o mundo estão atreladas ao nosso imaginário e é a partir dele então que nossas experiências se tornam significativas. 
A2-G1: Aqui uma borboleta.

A1-G1: Ah, sim.

A2-G1: (Abaixa-se e aponta com a mão a figura). As anteninhas da borboleta com as duas asas. Tá bem feitinha essa borboleta, inclusive. A daqui, ó.

\section{A1-G1: onde?}

A2-G1: Aqui, ó.

A1-G1Assim ó (reproduz a figura com as mãos, indicando o desenho). Daqui de cima.

A2-G1: A visão é daqui, de onde a Taís tá, que tem a visão.

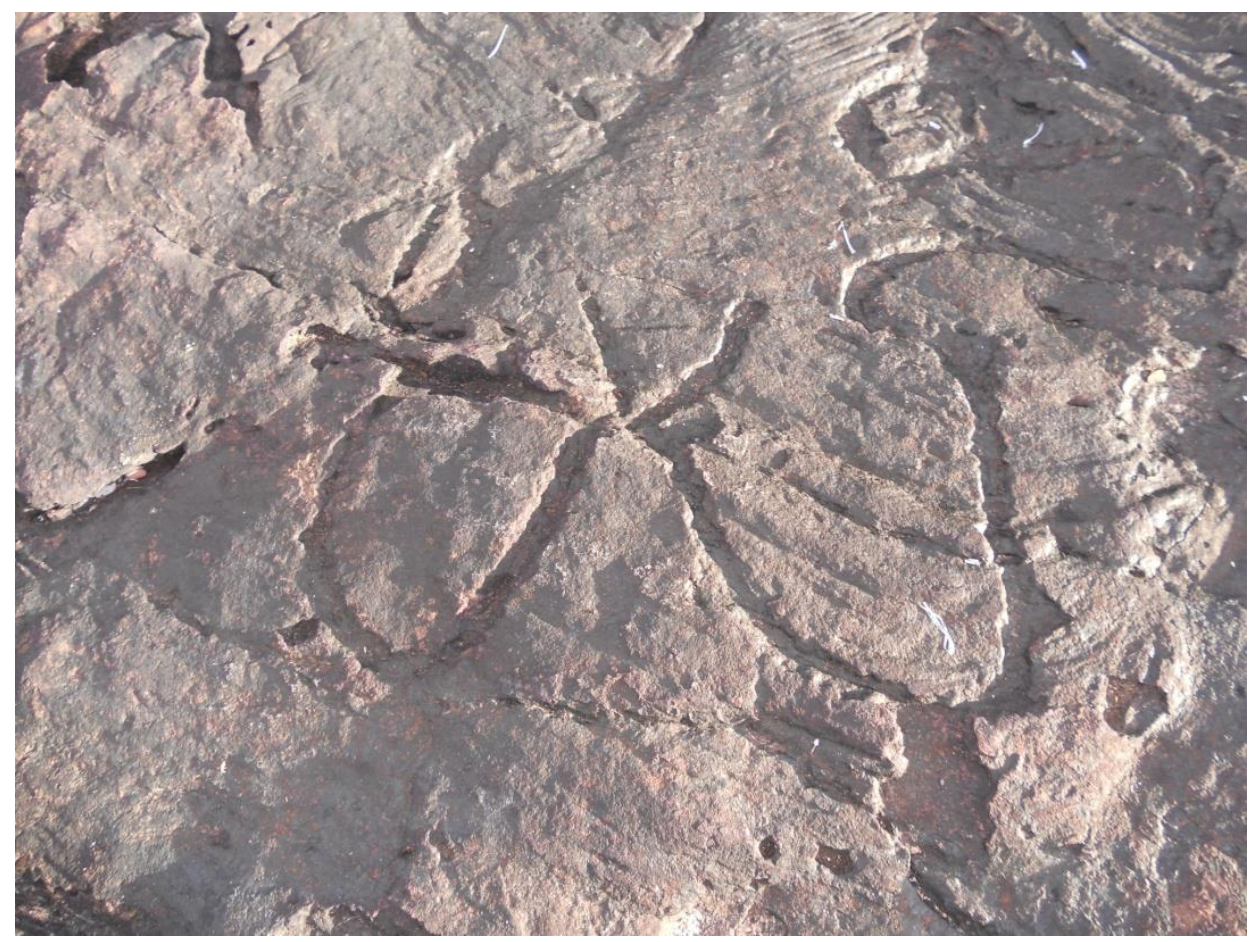

Foto 20: Borboleta

Em alguns momentos outros aparelhos sensoriais são utilizados e, ao percorrer as mãos pelo lajedo parece desenhar o objeto imaginado

A1-G1 Ah! Isso aqui é um... Vem cá, daqui ó. Isso é um bicho. Vem cá. Isso é um boizinho. Ó, tá perfeito (aponta e depois tateia). As patinhas, o corpo e a cabeça. Isso é perfeito um animal. (abaixa novamente e reproduz as formas com a mão). O corpo, as pernas... E a cabeça. 


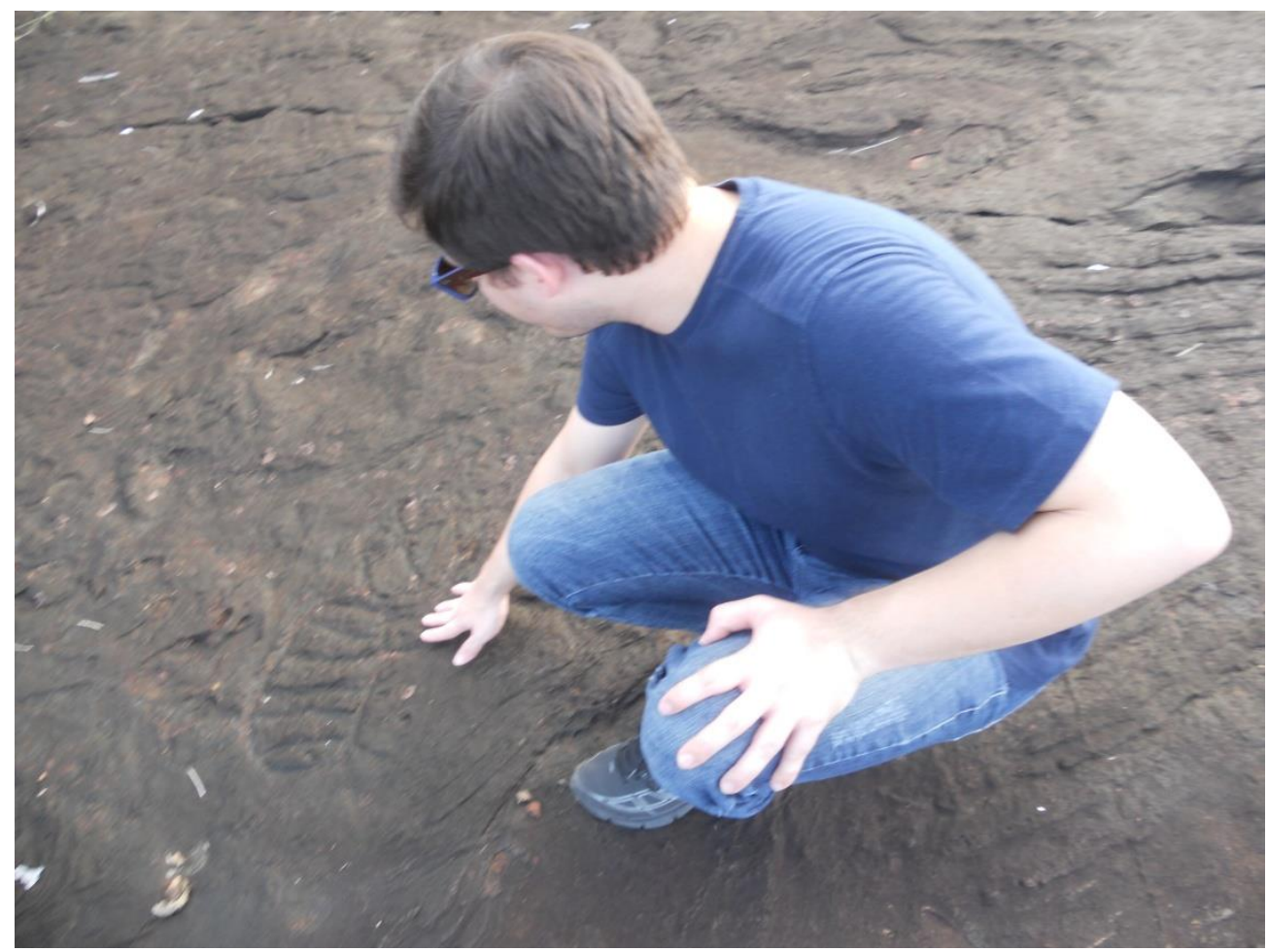

Foto 21: A1-G1 identificando as formas.

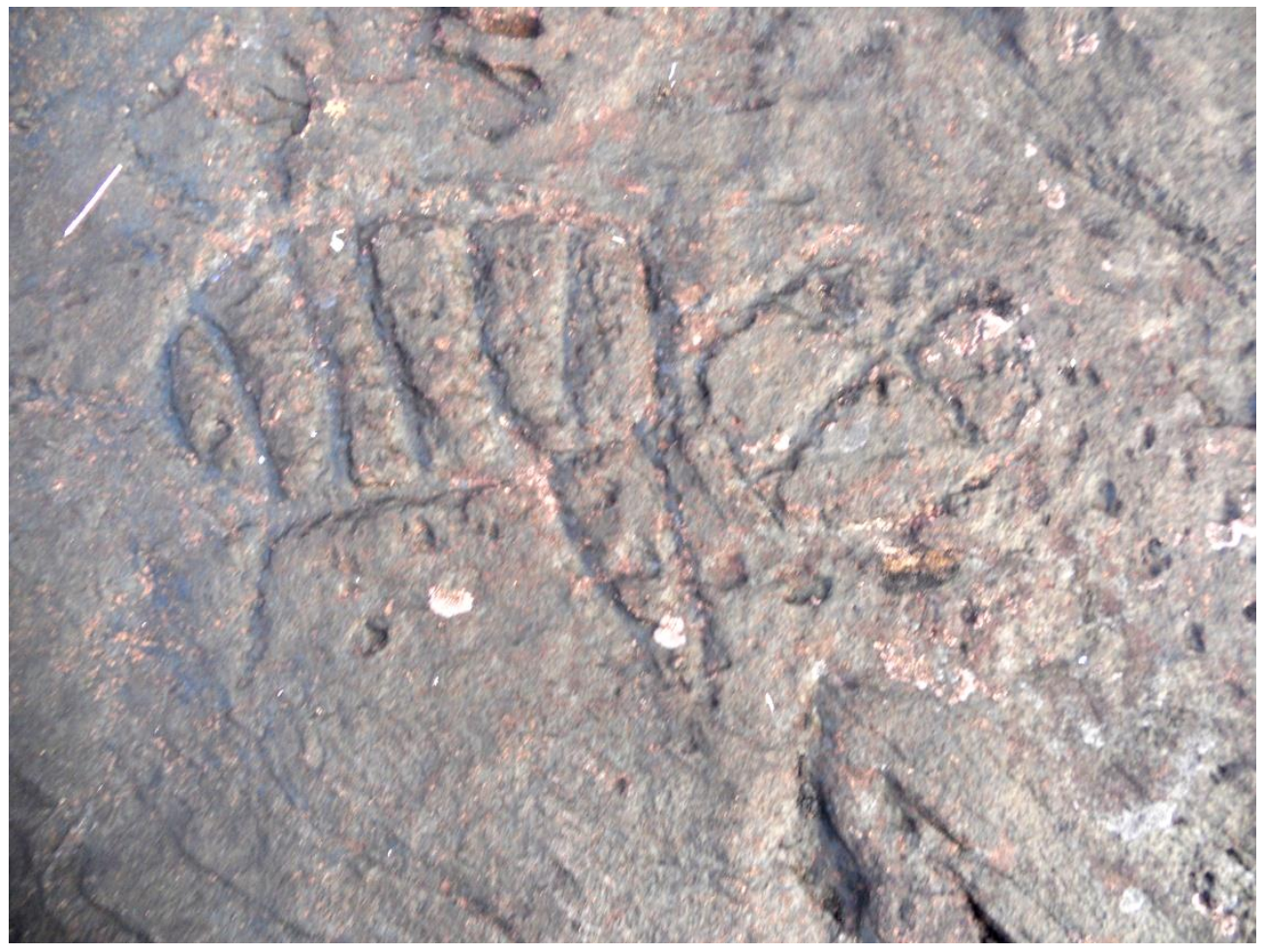

Foto 22: "Boizinho" 
O grupo 3 foi relativamente menos substancial em suas interpretações dos desenhos. De sobremaneira a timidez travou algumas palavras e barrou alguns gestos. No entanto, o pouco dito trouxe grandes reflexões e questionamentos.

A1-G3: É interessante observar como que a cada vez que eu vou lá vejo coisas diferentes, um mesmo desenho parece mudar de formato.

O entrevistado do segundo grupo ratificou a afirmativa transcrita acima e declarou que:

\begin{abstract}
A1-G2: O encarregado lá, ele tava falando que dependendo da hora que você vem aqui, parece que você percebe figuras diferentes. Você volta aqui de manhã, parece que tá dum jeito, depois você volta, tá doutro. E eu to vendo que isso aqui pode ser em relação à luminosidade mesmo, dependendo da posição que o sol tiver, ele vai destacar mais um... Um... Um... Uma gravura dessa, do que em outros momentos, né? Um dia mais nublado, um dia mais ensolarado, vai dando... A pessoa vem e tem percepção de tá vendo coisa que não tinha visto ainda... (Pausa). Interessante esse trem. (Aponta, toca a figura e percorre seus traços).
\end{abstract}

Esse questionamento reflete a problemática aqui apresentada. Como a cada experiência existem varias possibilidades de mundo a partir de diferentes imaginários. Logo após uma figura ser identificada pelo ator do segundo grupo, pude construir um exemplo dessas infinitas possibilidades que nos apresentam as coisas do mundo. 


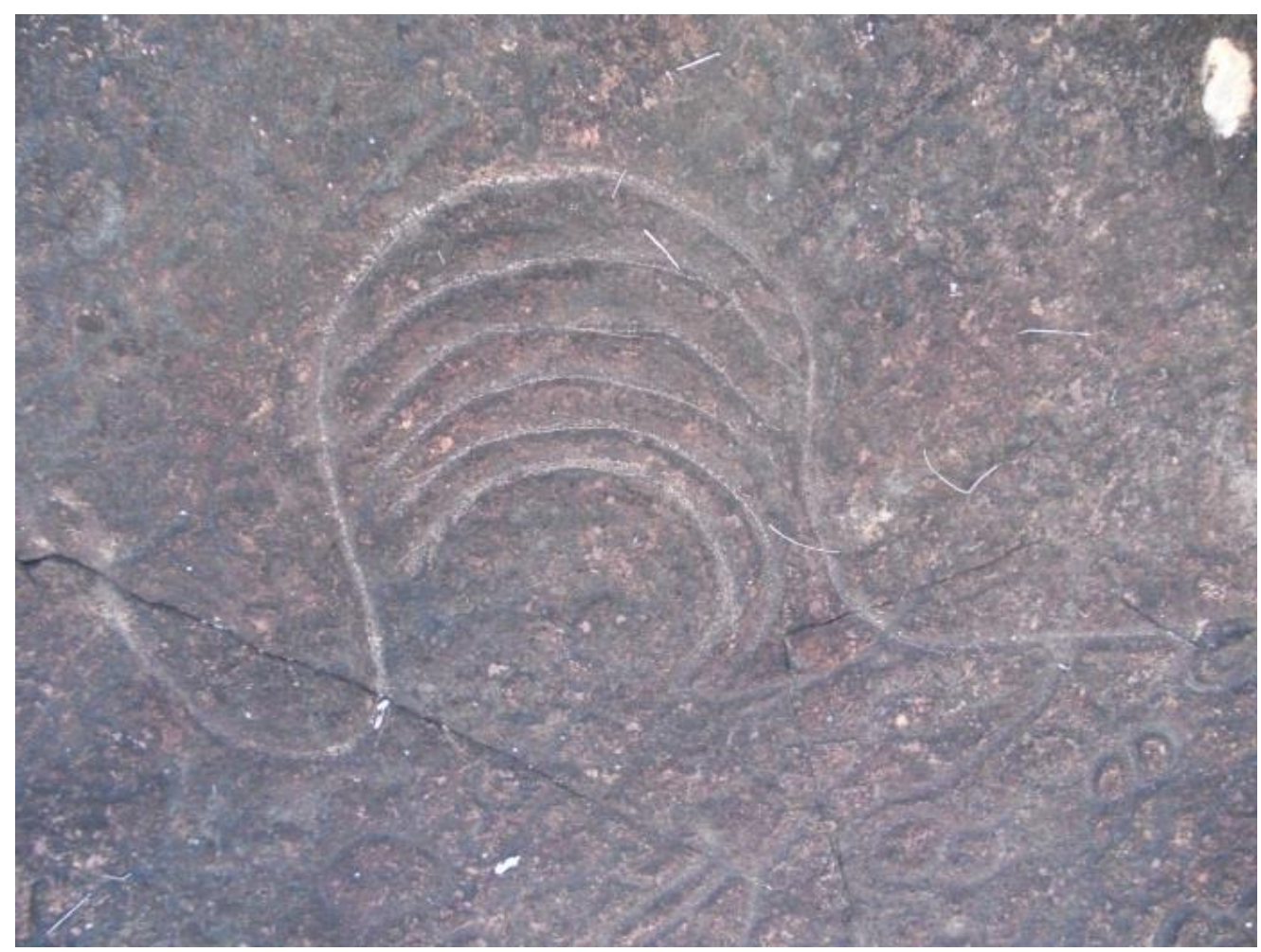

Foto 23: "Polvo"

Essa foi a figura identificada. A partir disso, me dei conta que dias antes, quando da visita do primeiro grupo, essa figura também foi localizada, no entanto, foi interpretada de outra forma: 


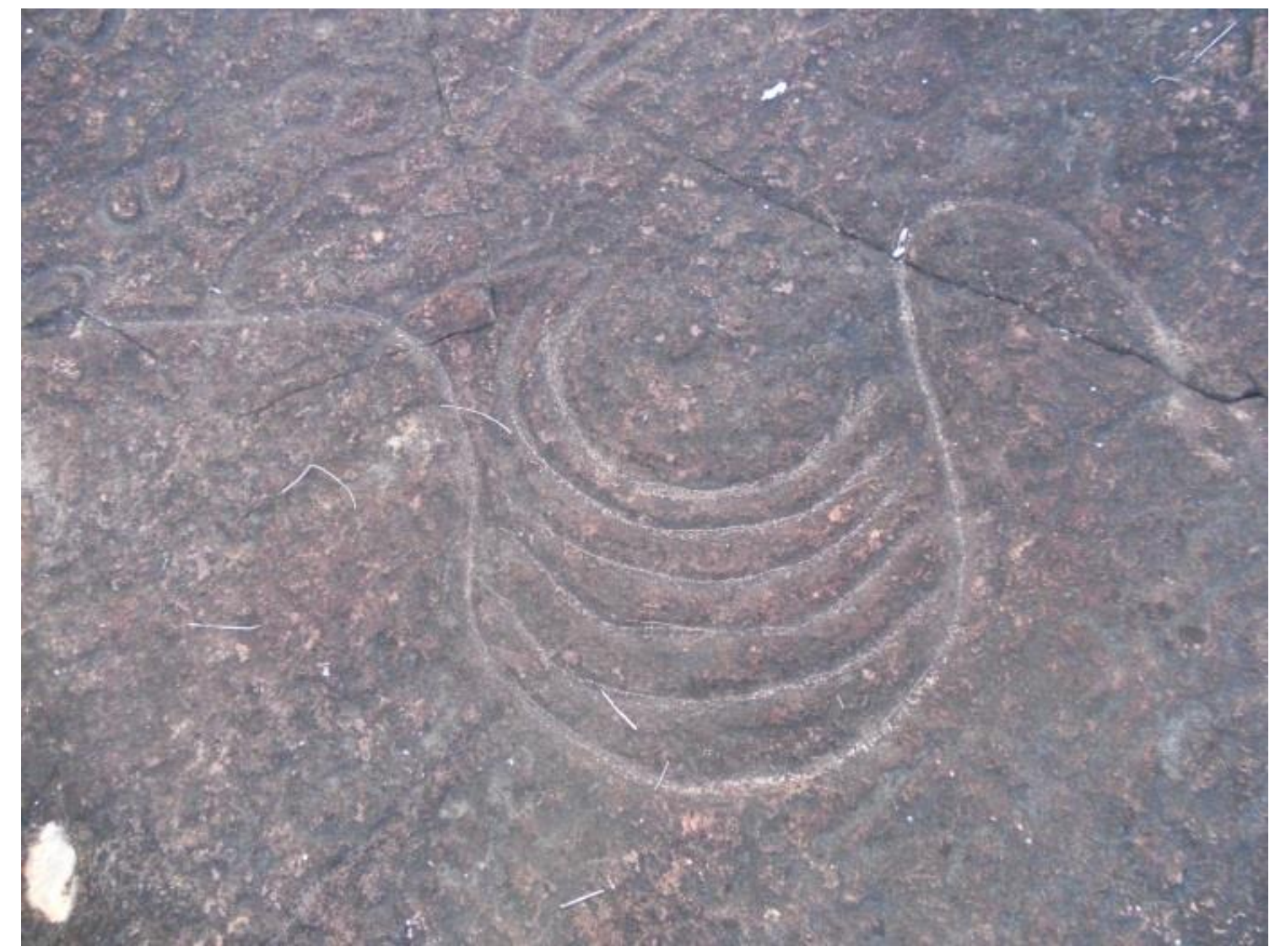

Foto 24: “Água”, "onda”.

E o mais incrível, vasculhando meus arquivos, localizei fotografias de antigas visitas ao sítio Bisnau e encontrei a seguinte foto e legenda.

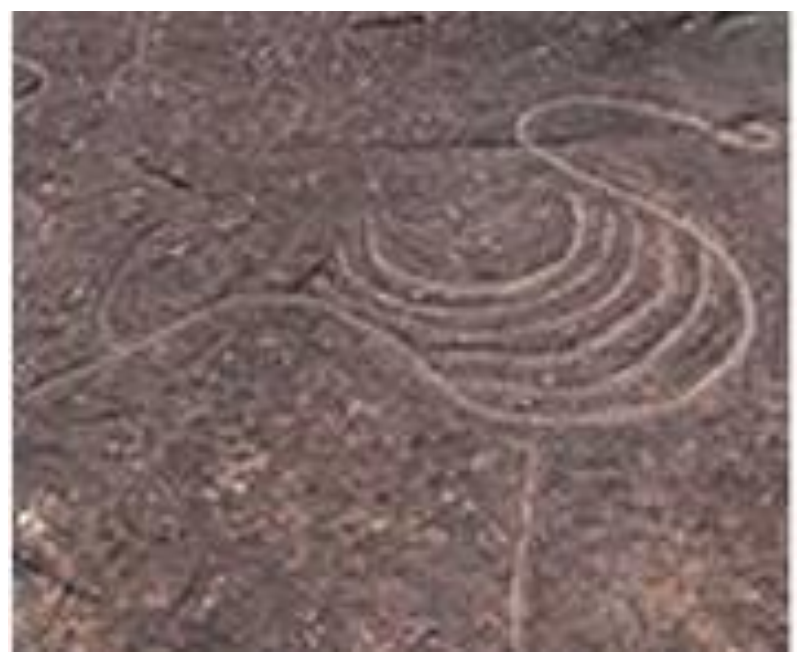

Foto 25: Pássaro", "Flamingo" 
Dessa forma, foi considerado também, como manifestação de relacionamento com o lugar visitado, as diversas versões sustentadas pelos turistas sobre o que seriam os motivos e formas presentes no lajedo do sítio Bisnau. Foi observado nas entrevistas, uma busca sucessiva por parte dos turistas em tentar identificar os desenhos, recorreram as suas lembranças que, armazenadas no imaginário iam dando volume ao antes amorfo.

\subsection{Que Bicho É Esse?}

A seguir são apresentados os desenhos mais observados pelos três grupos que visitaram o sítio arqueológico Bisnau e algumas de suas interpretações, ao mesmo tempo, convido o leitor ou quem quer que seja, a visitar o sítio e identificar as infinitas possibilidades que os milhares de traços e formas podem revelar.

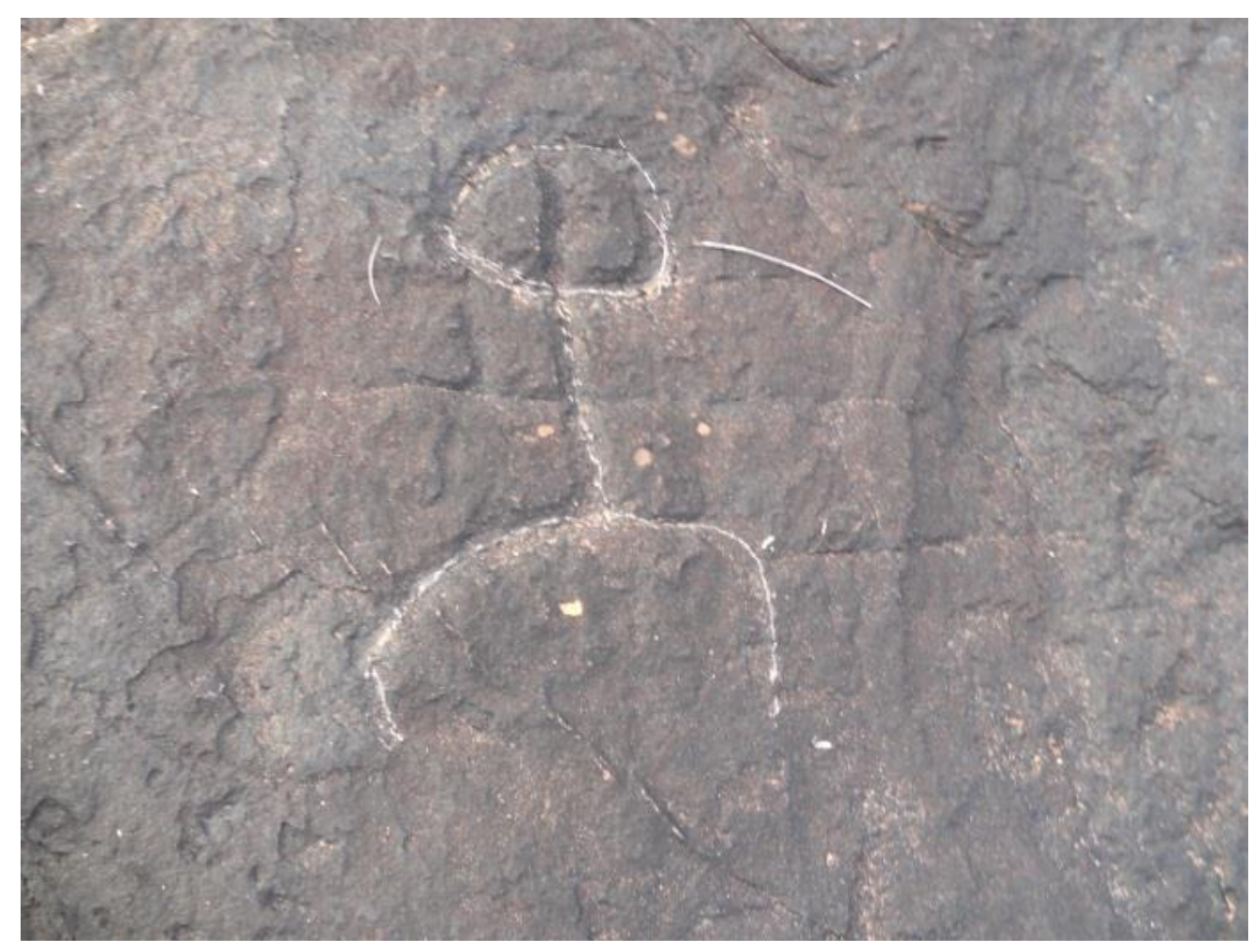

Foto 26: Para a maioria dos entrevistados é uma representação humana. 

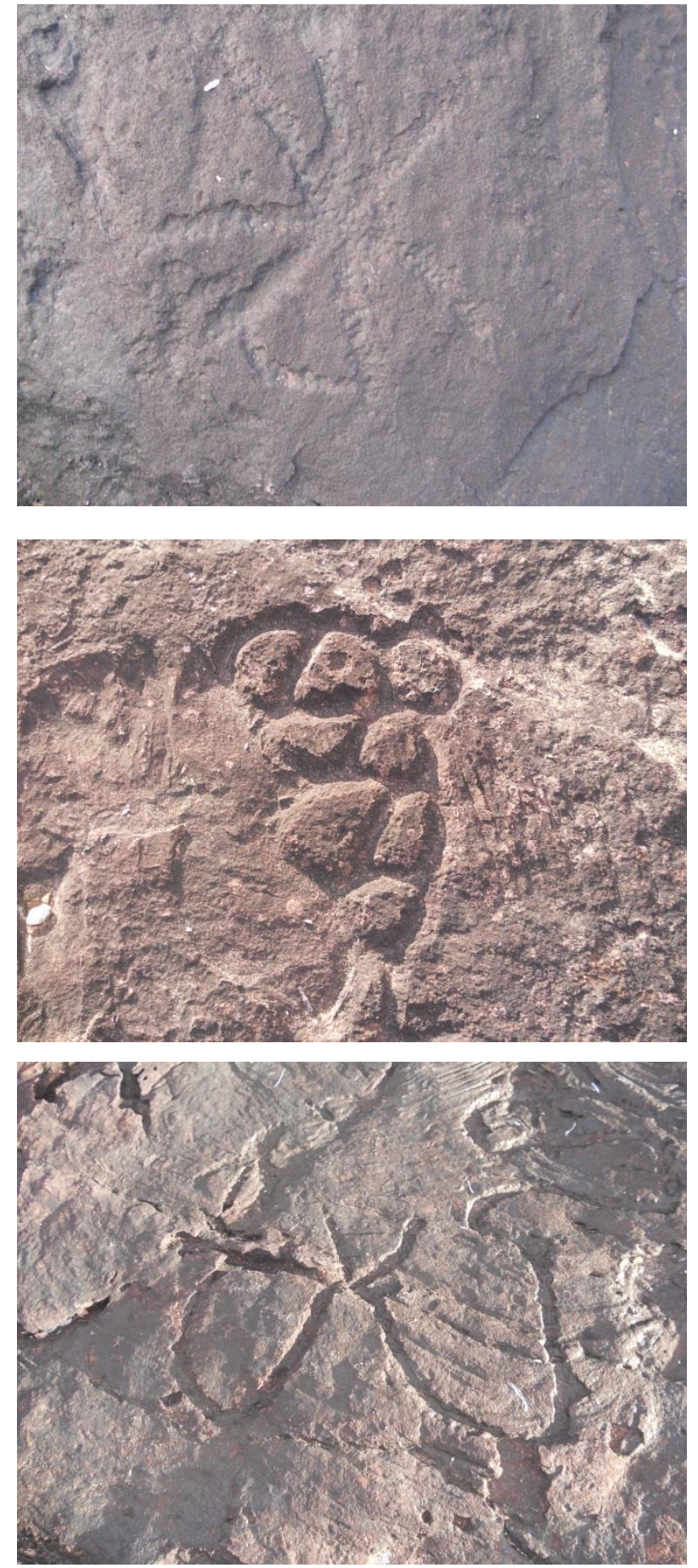

A1 - G1: "Uma aranha"

A2 - G1: "Uma aranha"

A1 - G2: Uma estrela

A2 - G3: Uma estrela

A1 - G1: "Cacho de uvas"

A2 - G1: "A mesa de reunião do sítio"

A1 - G1: "Uma borboleta"

A2 - G1: "Uma borboleta"

A1 - G2: "um laço de fita"” 


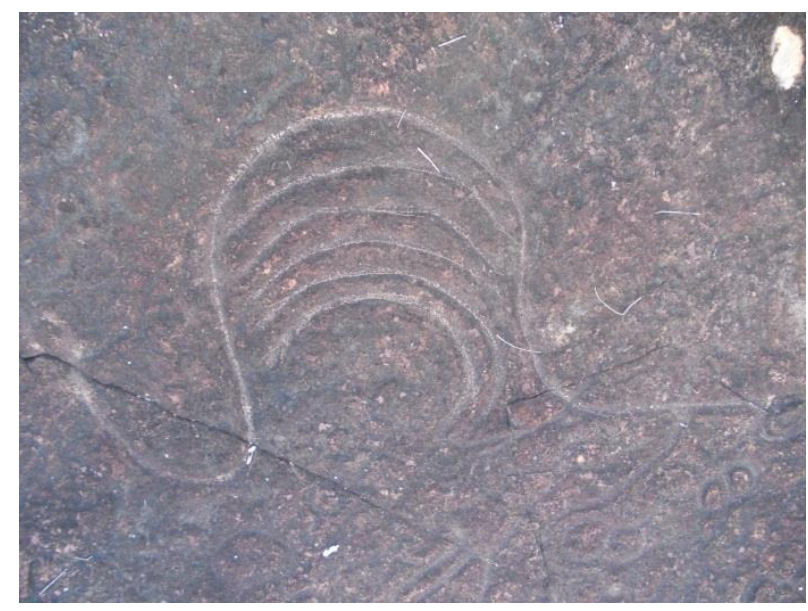

$$
\begin{aligned}
& \text { A1 - G1: "Água”" } \\
& \text { A1 - G1: "Uma onda"” } \\
& \text { A1 - G2: "Polvo" }
\end{aligned}
$$

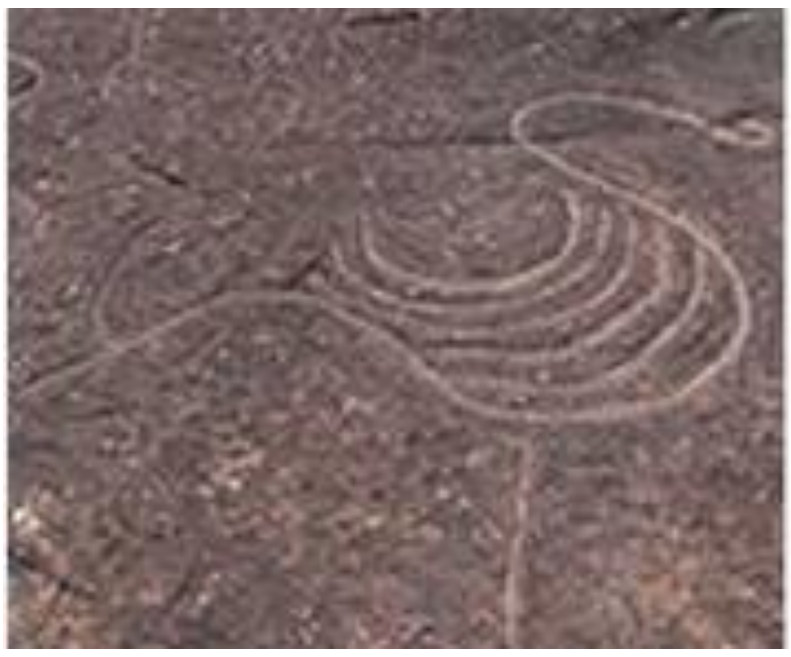

Flamingo?

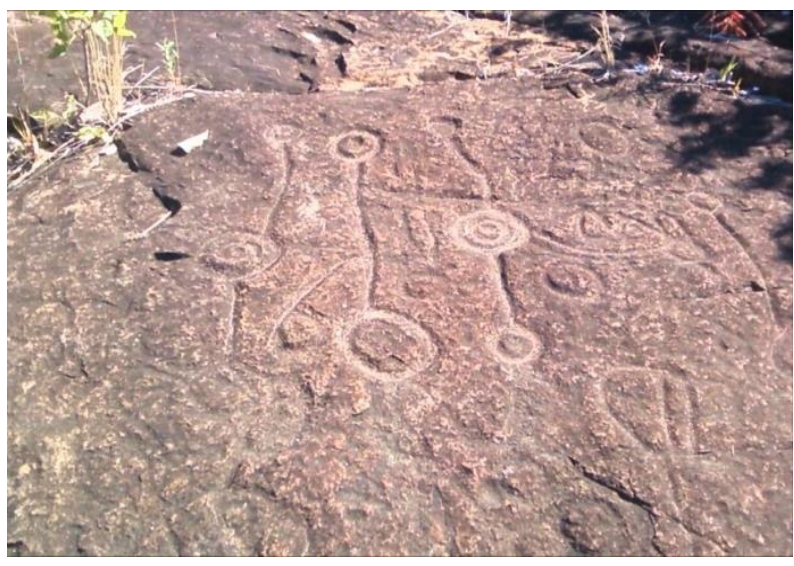

A1 - G1: "Uma espécie de representação do espaço sideral"

A2 - G1: "Círculos unidos por linhas"” 


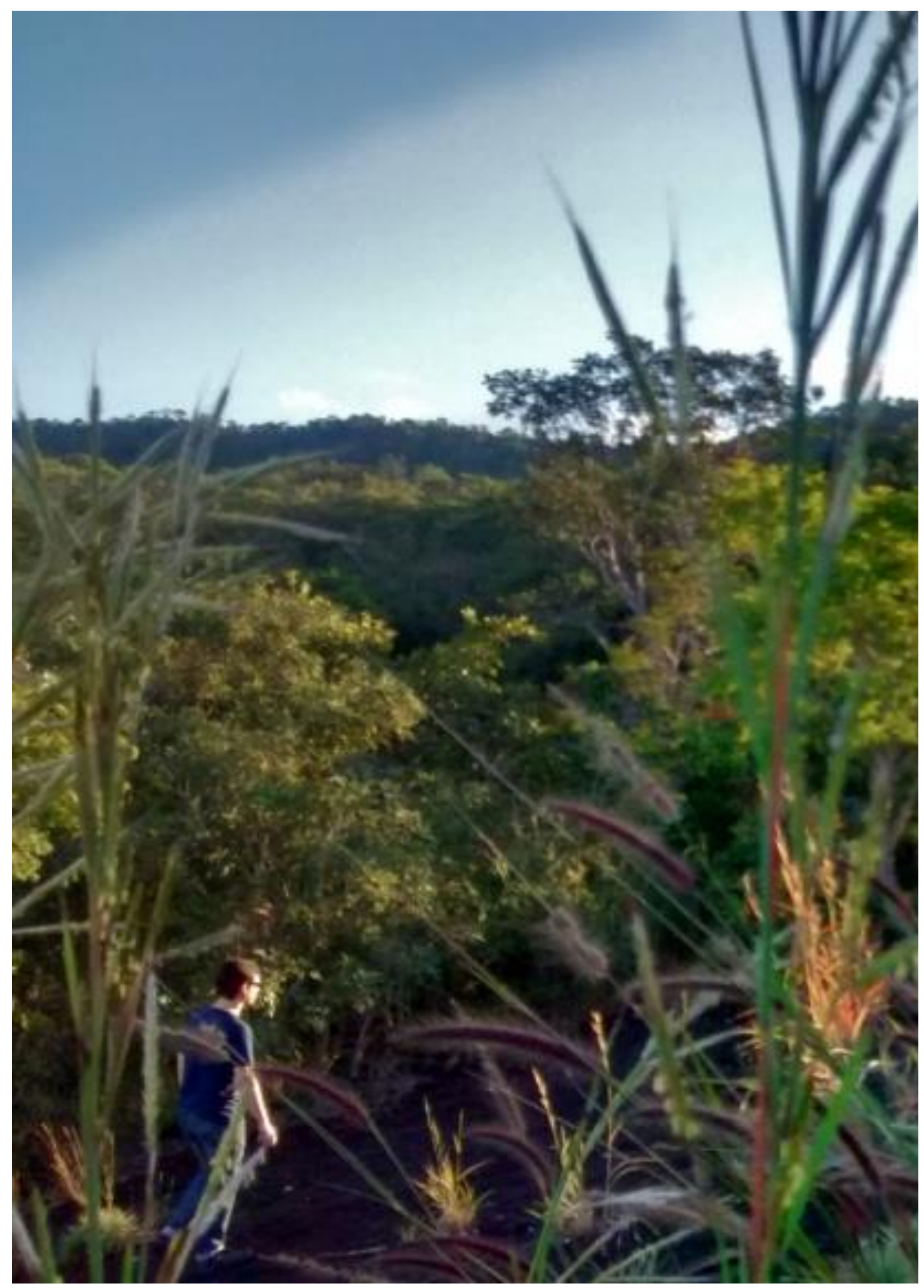




\section{CONSIDERAÇÔES FINAIS}

Destarte, conclui-se que os espaços e lugares, ou seja, todo o meio físico em que nos relacionamos dentro do mundo é estabelecido por sua prática, quando os homens se deslocam ou se estabelecem em determinado espaço geográfico. No turismo críamos simulações de espaços e lugares mentalmente, quando desejamos conhecer certo país, na vontade de provar da culinária e dos costumes de determinado povo.

Quando experimentamos um destino de forma indireta, recebemos diversas versões acerca desse destino. Um exemplo, Japão. Se assistirmos a BBC, conheceremos principalmente o lado econômico da potencia oriental. NatGeo? Os segredos dos seus mares e a violenta caça as baleias. Com isso e muito mais vamos delineando $o$ Japão, mentalmente, criando um imaginário acerca daquele país.

Certo! O Japão será nosso destino, com todos seus templos Xintoístas e Budistas conheceremos um pouco dessa religiosidade. Assim todo nosso imaginário construído através das experiências indiretas será projetado na experiência direta, no momento da visita, na experiência física do espaço imaginado. Essa nova experiência, muito mais complexa, vai aliar tato, olfato e paladar à experiência anterior, bem como uma visão e audição genuínas, sem manipulação. Perceberemos a realidade de forma orgânica através de todo nosso corpo, sentiremos o clima, a receptividade do povo, os gostos e cheiros da terra.

$\mathrm{Na}$ relação intima dos homens nos espaços haverá transformação em ambas as partes. A partir disso surgirão lugares, ou seja, espaços praticados em profundidade, onde se estabelecem relações e sentimentos pelos ambientes e suas pessoas e objetos. 
No turismo, as duas formas de experiência ${ }^{18}$, direta e indireta são fundamentais. A primeira, no sentido de tomada de consciência de certo atrativo apresentado, de maneira a incitar o desejo de um potencial turista a visitar seu destino. A segunda, proporcionar o oferecido, bem como surpreender 0 visitante com novas experiências. As surpresas se tornaram relatos da experiência vivida, ou seja, combustível para a criação e/ou a manutenção de imaginários.

Percebemos, através das entrevistas, que as relações de cada entrevistado com os espaços são únicas e singulares. A partir dos relatos de cada ator que experimentou o espaço turístico do sítio arqueológico Bisnau desvelamos lugares e não-lugares resultantes do envolvimento dos sujeitos nos diferentes espaços.

Percebemos também, como o imaginário trabalha nos diversos momentos da experiência turística, preenchendo os espaços de sentido, conferindo-lhes possibilidades infinitas para o sujeito que se relaciona.

Espaço e/ou lugar é uma apropriação subjetiva que envolve práticas, memórias e narrativas. A experiência nos espaços revela possibilidades infindáveis de troca e intimidade, desencadeando memórias, projetando imaginários, os quais por sua vez podem ser externados nos relatos e narrativas da viagem.

Normalmente nos ligamos a determinados lugares após uma longa e lenta experiência de convívio. Mas há casos onde a experiência, mesmo que curta, cria um laço emocional com o lugar devido a sua intensidade (Pellini, 2014).

A intensidade em que se dá nossa experiência nos espaços vividos é influenciada pelo nosso imaginário, que enquanto reservatório agrega imagens, lembranças, leituras de vida que se projetam na nova realidade vivida e a contorna.

\footnotetext{
18 Aqui se apresenta dois grupos de experiência, num sentido macro. Entretanto, estas serão compostas por outra infinidade de experiências.
} 
Nós aprendemos a ver, a ouvir, a sentir. Nós aprendemos a observar e a não observar. Aprendemos o que ver e o que não ver, aprendemos a apreciar um paladar enquanto refutamos outros, aprendemos a admitir certos cheiros enquanto nos enojamos com outros. Nossa interpretação do mundo é baseada na interpretação que fazemos da realidade e não na realidade em si. Conhecemos o real apenas naquilo que a mente pode assimilar ou foi doutrinada a aceitar (Pellini, 2014).

Nossas experiências, portanto, são influenciadas por aquilo que já vivemos e já aprendemos. Toda nossa bagagem de vida, guardada no reservatório do imaginário influenciará nas experiências, transformando os sujeitos e os espaços praticados por eles. .

De certa forma, também fui um ator revelador das possibilidades relacionais e afetivas com os espaços vividos durante todo o percurso. Estive por várias vezes realizando o trajeto de Formosa, Goiás para o sítio arqueológico Bisnau, Construí e desconstruí por vezes um espaço turístico, me reestabelecia no meu lugar, porém construí um lugar no sítio bisnau, ali já tenho apresso. Partilhei aquele espaço com grupos de duas, três pessoas, mas também com 30 pessoas, o pratiquei pela manhã, ao meio-dia e no fim de tarde.

O tempo que já despendi naquele espaço me relacionando com ele e com o outros que o vivenciaram comigo, foi sim um fator para que eu desenvolve-se essa relação intima e valorativa com o sítio. No entanto, vários outros fatores também operaram, minha bagagem como arqueólogo, já dotava aquele espaço, antes mesmo de experimentá-lo, de uma carga mnemônica complexa, revelando a ação humana pretérita nas gravuras do lajedo.

A cada visita, a cada nova olhar sobre a paisagem e o espaço visitado, ouvi os relatos dessa experiência dos vários sujeitos que vivenciam o sítio. Pra mim, é espantoso e ao mesmo tempo formidável a quase infinita possibilidade de interpretação de um mesmo ou diferentes desenhos. 
Assim também são as experiências nos espaços e lugares, as mais variadas relações e escolhas, uns querem desfrutar do pôr do sol no lajedo, outros desejam a pamonha, há outros ainda que só anseiam pela volta, já cansados da maratona.

O intuito aqui era desvelar como o imaginário faz parte do fenômeno turístico ao sítio arqueológico Bisnau em Formosa - Goiás, revelando-se nas diversas experiências na viagem e em visitação e como essas experiências e sentimentos adquiridos transformam os espaços e os lugares a partir da construção objetivo/subjetiva da realidade por parte daqueles que o praticam.

E mais, parece-me estar justamente no imaginário trabalhado por vários discursos cientifico, ufologista - acerca do sítio arqueológico Bisnau a vida e a sobre vida deste enquanto atrativo turístico e que desta maneira vem recebendo visitação. No entanto, é necessário maior vínculo entre as esferas desse fenômeno turístico. Maior envolvimento e respeito para com a comunidade, maiores estudos acerca da capacidade e dos limites e possibilidades de se fazer turismo nesse espaço. Parte destes princípios um turismo de maior qualidade e respeito aos recursos históricos, naturais e sociais que são únicos, limitados e perecíveis.

Alguns componentes paisagísticos e históricos da região do sítio Bisnau, reconhecidos como atrativos, possibilitam aludir um espaço turístico. No entanto, é necessário que haja a manutenção dos espaços e lugares que o compõe, seja pensando na estrutura física necessária a receber visitação e promover a região turisticamente, bem como na revelação de seu encantamento, presente nos diversos imaginários acerca principalmente das origens do lajedo rupestre.

Cabe ressaltar, ainda que não seja objeto dessa dissertação, o papel dialógico, cooperativo e corporativo que deve desempenhar os vários atores que possibilitam e que podem promover o turismo da região. As políticas públicas voltadas para turismo no município de formosa - Goiás mesmo expondo os sítios Bisnau e Toca da Onça como atrativos turísticos parecem não estabelecer propostas e parcerias com a comunidade, no intuito de promoção e preservação desses destinos e, que traga algum benefício para as localidades envolvidas. 
É de conhecimento de muitos de nós e, também do meu, enquanto pesquisador em turismo e em arqueologia, a importância do turismo na geração de benefícios para a comunidade envolvida - seja renda, seja autovalorização - e para preservação e fruição da memória e importância do patrimônio arqueológico. No entanto, as diversas escalas de atuação dos atores envolvidos para que aconteça um turismo que respeite os limites e diferenças de cada lugar parecem estar destoantes.

O turismo precisa proporcionar destinos com possibilidades de experiências genuínas ao invés de experiências infinitas, é preciso ficar marcado. A partir da vivencia de um espaço, carregar dele uma lembrança, um sentimento. Partirá daí novos relatos sobre o destino, o que vai cada vez mais firmar o atrativo e sua singularidade, propiciando, no caso do sítio arqueológico Bisnau, a propagação da história regional preservada em sua paisagem.

É preciso então que as potencialidades de um espaço turístico sejam transformadas em lugares para aqueles que o visitam, desencadeando sentimentos e lembranças que hora ou outra serão passadas a alguém ou reveladas à memória. Não se trata de criar um cenário turístico, mas proporcionar a melhor forma de viver a essência do lugar e do seu povo é ter o entendimento do potencial não só do atrativo, mas de todo o destino. 


\section{REFERÊNCIAS}

ARAÚJO, B.S.R. Conceito de aura, de Walter Benjamin, e a indústria cultural. Pós v.17 n.28, São Paulo, 2010.

BARRETO, Margarita. Manual de iniciação ao estudo do turismo. 9.ed. Papirus. Campinas, São Paulo, 2000.

BARRETO, M. Turismo e Legado Cultural: as possibilidades de planejamento. São Paulo: Papirus, 2000.

BARRETTO, Margarita. Cultura e turismo: Discussões contemporâneas Campinas, SP: Papirus, 2007.

BENJAMIN, W. Magia e técnica, arte e política: ensaios sobre literatura e história da cultura. Obras escolhidas, vol. I. São Paulo: Brasiliense, 1987.

BERTRAN, Paulo História da Terra e do Homem no Planalto Central: Eco-história do Distrito Federal - 1를 edição, Brasília, Solo Editores, 1994.

BRANDIM. A. C. M. S. Paul Ricoeur e Michel De Certeau: A Hermenêutica da Falta como Produção de Sentidos ou A Hermenêutica dos Rastros do Outro. Revista de Teoria da História 2010

BRASIL, Ministério do Turismo. Segmentação do Turismo: Marcos Conceituais. Brasília: Ministério do Turismo, 2006.

BRASIL, Ministério do Turismo. Turismo Cultural: orientações básicas - 3. ed.Brasília, 2010.

BRUYNE, Paul de. Dinâmica da pesquisa em ciências sociais. 3 ed. Rio de Janeiro. Editora. Francisco Alves, 1991. 
CASTROGIOVANNI. A. O Lugar Da Geografia No Entre-Lugar Do Espaço Turístico:Uma Viagem Complexa. Porto Alegre, 2007.

CASSAB, Clarice. Epistemologia do espaço na obra de Milton Santos: breve panorama. Geografias, Belo Horizonte, p. 98-108 janeiro-junho de 2008.

CARLOS, A. F. A. O Turismo e a Produção do Não-Lugar. In: Turismo: Espaço, Paisagem e Cultura. Editora Hucitec. 1999.

CERTEAU, Michel de. A invenção do cotidiano: artes de fazer. Petrópolis: Vozes, 1998.

COSTA, E.R. O conceito de aura em Walter Benjamin - Unicamp 2012

DIAS. KARINA. Le paysage: entre Le vu et l'invu, pour une pratique paysagère dans le quotidien. Tese em Artes Plásticas defendida em setembro de 2007 na Université Paris I - Panthéon Sorbonne

FOGAÇA, E. Mãos para o pensamento: a variabilidade tecnológica de indústrias líticas de caçadores-coletores holocênicos a partir de um estudo de caso - as camadas VIII e VII da Lapa do Boquete (Minas Gerais, Brasil 12.000/10.500 B.P.). 2001. Tese (Doutorado) - PUCRS, Porto Alegre, 2001.

FUNARI, Pedro Paulo Abreu. Arqueologia. 2. ed. São Paulo, Editora Contexto, 2006.

GASPAR, MADU. Arte Rupestre no Brasil. São Paulo: Ed. Zahar, 2003.

GASTAL, Susana; MOESCH, Marutschka Martini. Turismo, Políticas Públicas e Cidadania. São Paulo: Ed. Aleph, 2007.

GASTAL, Susana. Turismo, imagens e imaginário. Ed. Aleph, 2005. 
Gordon Child - Introdução a arqueologia. Coleção Saber. Lisboa, 1987 http://pt.scribd.com/doc/165601829/Gordon-Child-Introducao-a-Arqueologia-pdf

GRABURN, N. "Antropologia ou Antropologias do Turismo?”. In: Graburn, N., et alli. (orgs.). Turismo e Antropologia: novas abordagens. Campinas: Papirus, 2009.

GUIMARÃES. S. T. L. Reflexões a respeito da paisagem vivida, topofilia e topofobia à luz dos estudos sobre experiência, percepção e interpretação ambiental. Geosul, Florianópolis. 2002.

HOLZER, Werther. O conceito de lugar na geografia cultural-humanista: uma contribuição para a geografia contemporânea. Revista GEOgrafhia. Ano V ํㅜ10. Rio de Janeiro 2003

ICOMOS. Carta de Turismo Cultural. Seminário Internacional de Turismo Contemporâneo e Humanismo. Bruxelas, 1976

LEITE, Adriana Filgueira. O Lugar: Duas Acepções Geográficas. Anuário do Instituto de Geociencias - UFRJ. Volume 21, Rio de Janeiro, 1998.

MARISANGELA, Martins. Problematizando o imaginário: limites e potencialidades de um conceito em construção - $O$ imaginário da militância comunista em Porto Alegre (1945-47)

MAFFESOLI, Michel. O imaginário é uma realidade. Porto Alegre, 2001.

. O conhecimento comum. Porto Alegre: Sulina, 2007.

MERLEAU-PONTY, Maurice. Fenomenologia da Percepção. $2^{\underline{a}}$ ed. São Paulo: Ed. Livraria Martins Fontes Editora Ltda, 1999.

MOESCH, Marutschka Martini. Epistemologia Social do Turismo. Tese de Doutorado. São Paulo, 2004. 
MOLETTA, Vania Florentino. Turismo Cultural. 2. Ed. Porto Alegre: SEBRAE/RS, 2000.

MOREIRA. Virginia. O método fenomenológico de Merleau-Ponty como ferramenta crítica na pesquisa em psicopatologia. Psicol. Reflex. Crit. vol.17 no.3 Porto Alegre 2004

MORAIS. José Luís. Arqueologia da Região Sudeste. São Paulo, Revista USP, n 44, p. 194-217, 1999.

NETTO, Alexandre Panosso; Filosofia do Turismo: Teoria e Epistemologia. Ed. Aleph , 2005.

NETTO, Alexandre Panosso; GAETA, Cecília. Turismo de experiência. São Paulo: Senac, 2010.

NORA, Pierre. Entre memória e História: a problemática dos lugares. Projeto História, São Paulo, n. 10, dez. 1993.

OLIVEIRA, J. E; VIANA, S. A. O Centro-Oeste antes de Cabral. Revista USP, São Paulo, n.44, p. 142-189, dezembro/fevereiro 1999-2000.

PAVIANI, Jaime. Epistemologia prática - ensino e conhecimento científico. Caxias do Sul: EDUCS, 2009.

PROUS. A. Arqueologia Brasileira - Editora Universidade de Brasília, Brasília/DF, 1992.

RAMBELLI. Gilson, BAVA, Paulo Fernando, CALIPPO. Flávio. Arqueologia e Turismo: duas ferramentas para a construção, gestão e manutenção do patrimônio cultural. Revista eletrônica Patrimônio: Lazer e Turismo.

SANTOS, M. Por uma Geografia Nova. São Paulo: Hucitec, Edusp, 1978. 
SANTOS, M. A natureza do espaço. São Paulo: Hucitec, Edusp, 2002

SANTOS, Milton. Pensando o espaço do homem. 4. ed. São Paulo: Hucitec, 1997.

SILVA, Gislene. Imaginário coletivo: estudos do sensível na teoria do jornalismo. Revista Famecos 2010. Porto Alegre.

SILVA, Juremir Machado. Tecnologias do Imaginário. 2006

SOCHODOLAK, Hélio; OLIVEIRA, Oseias. História, Relatos, Representações. Revista Tempo, Espaço e Linguagem; Vol. 3, No 2. Ed. Unicentro, 2012.

SODRÉ, Muniz. As estratégias sensíveis afeto, mídia e política. Petrópolis, RJ: Vozes, 2006.

SWAIN, Tânia Navarro. "Você disse imaginário?". In: SWAIN, Tânia N. (Org.). História no Plural. Brasília: Editora da Universidade de Brasília, 1994.

TUAN, Yi-Fu. 1975. Place: an experiential perspective. Geographical Review, 65 (2): 151-165.

TUAN, Yi-Fu. Espaço e lugar: a perspectiva da experiência. São Paulo: Difel, 1983.

TUAN, Yi-Fu. Topofilia: um estudo da percepção, atitudes e valores do meio ambiente. São Paulo: Difel, 1980.

TRIGGER. B.G. História do Pensamento Arqueológico. 2004

WIDMER, Gloria Maria. Turismo Arqueológico. In: NETTO, Alexandre Panosso; ANSARAH, Marília Gomes dos Reis. Segmentação do mercado turístico: estudos, produtos e perspectivas. Barueri, SP: Manole, 2009 
WÜST, I. Continuidade e Mudança - para uma interpretação dos grupos ceramistas pré-coloniais da bacia do rio Vermelho, Mato Grosso. Tese de Doutorado, USP, São Paulo, 1990.

YÁZIGI, Eduardo. A Alma do Lugar: Turismo, planejamento e cotidiano. São Paulo: Editora Contexto, 2001.

Sites consultados

Pedro Ignácio Schmitz. Os primeiros povoadores do Cerrado in: http://www.comciencia.br/reportagens/arqueologia/arq11.shtml

www.iphan.gov 